\title{
Microeconomic aspects of Economic Growth in Eastern Europe and the Former Soviet Union, 1950-2000
}

\author{
By: Sergei Guriev and Barry W. Ickes
}

Working Paper Number 348

November 2000 


\title{
Microeconomic Aspects of Economic Growth in Eastern Europe and the Former Soviet Union, 1950-2000*
}

\author{
Sergei Guriev $\quad$ Barry W. Ickes ${ }^{\dagger}$
}

\begin{abstract}
The theme of this paper is the microeconomics of economic growth in Central and Eastern Europe (CEE) and the Newly Independent States (NIS) over the period 1950-2000. The key structural change in this region is the end of the socialist regime in 1989 and 1992, and the subsequent attempt at transition to a market economy. We begin the paper with an examination of the key legacies from the socialist period. We then examine the key microeconomic actors in transition economies: households, enterprises, and government officials. Although there are many common processes at work, differences in economic performance tend to coincide with the geographical divide. Legacies play an important part. We also argue that differences in openness also plays an important role in generating different outcomes. These factors, combined with defects in the political and legal system, have given rise to a vicious circle of resistance to reform in the NIS.
\end{abstract}

*This paper is a part of the Global Research Project 'Explaining Growth' sponsored by the Global Development Network. The views expressed are those of the authors and should not be attributed to the World Bank and other sponsors. We thank Gur Ofer and Lyn Squire for their numerous suggestions and advice at many stages of this work. We are also grateful for comments from Francois Bourguignon, Nauro Campos, Micael Castanheira, Angus Deaton, Bill Easterly, Randy Filer, Tore Gylfason, Manny Jimenez, Eric Livny, Valery Makarov, Janet Mitchell, Vladimir Popov, and conference participants in Prague, Cairo, Bonn and Moscow for helpful discussions and comments.

${ }^{\dagger}$ The New Economic School (email: sguriev@nes.ru).

‡Department of Economics, The Pennsylvania State University, and The New Economic School (email: bwickes@psu.edu). 


\section{Non-Technical Summary}

The purpose of this paper is to examine the microeconomic aspects of growth in the economies of Central and Eastern Europe (CEE) and the Newly Independent States (NIS). Growth in this region is dominated by the response to economic transition from the command economy. The transition process represents a structural break from the growth process of the socialist period. Resumption of growth thus requires a successful resolution of the transition. In some CEE countries a sustainable turnaround to growth, recovering and even exceeding pre-reform GDP levels, has already taken place. In the NIS, on the other hand, most economies are still experiencing output decline or stagnation. Explaining the contrasts in performance along the microeconomic dimension is the primary goal of this paper.

Let us first define the major microeconomic determinants of growth in a transition economy by looking at the main microeconomic agents, i.e. firms and households. For a developing economy to grow, households should choose to save and accumulate human capital, and then supply that capital and labor to emerging firms. In transition countries, the situation is somewhat different, since their economies have already been industrialized. The labor force has acquired the necessary technical skills and the physical assets are in place. Moreover, there exist large enterprises that resemble modern capitalist firms. Therefore, the microeconomic problems of transition are slightly different from those of development.

Households choose how much to save and in which firms to work. Also, they may choose to become entrepreneurs and establish new businesses. Existing firms make the restructuring choices, changing both outputs and inputs, including the size and composition of their workforces.

We begin with a discussion of the pre-reform growth experience, trying to identify the legacies that influence the experience of growth patterns in transition. We argue that the Soviet growth model placed the emphasis on extensive rather than intensive growth. The system provided few incentives for the diffusion of innovations, or for the establishment of new firms and technologies. This resulted in very low elasticities of substitution of labor and capital, implying that the return to increasing capital intensity decreased dramatically during the latter period of socialism. The most important implications of the Soviet growth experience for the NIS countries were: (i) the geographical concentration of industry; and (ii) a structure of physical and human capital that is incompatible with the market economy. A related problem is the inherited transportation infrastructure. Given the large distances and the lack of competition in the distribution sector, markets are geographically segmented and regional monopolies have emerged.

We then look at recent developments in terms of the issues identified above. First, the level of household savings does not seem to be a problem. Given the under-developed financial systems, households hold precautionary savings at very high levels to insure themselves against negative in-come shocks. Also, households have tended to restore their stocks of savings, which were wiped out by hyperinflation at the beginning of the reforms. The problem, of course, is not the supply of savings but the demand. The banking system is still so immature that households prefer capital flight, including holding cash dollars. We also study private transfers. These have declined during the 
transition, but they still account for a substantial share of household incomes and play an important role in the alleviation of poverty and the financing of start-up businesses.

Our paper then discusses the accumulation of human capital. In terms of current levels of human capital, the NIS are doing as well as OECD countries, if not better. On the other hand, the stock of skills may not be suitable for the market economy. The Soviet education system has been very strong in mathematics and engineering, while marketing and finance skills are virtually absent. Another challenge is the long-term impact of a fiscal system under stress. It is not necessarily clear that the educational system that produced high levels of human capital under socialism can be maintained in the current environment.

The major microeconomic differences between CEE and NIS countries are low labor mobility, the lack of restructuring of existing firms and the slow formation of new businesses. What are the major impediments to labor mobility in the NIS? The key to under-standing mobility in the former Soviet Union is, again, the legacy of the Soviet growth model. Soviet industrialization resulted in a high geographical concentration of industry. Russia's industrial landscape reminds an observer of that of the US or the UK in the early stages of industrialization. There are whole towns and even regions with one single major employer. Huge distances also make these monopsonistic labor markets segmented. Therefore labor mobility is pretty much related to geographical mobility. Geographical mobility is, in turn, very costly in an economy with under-developed credit and housing markets. Cash-constrained workers cannot finance a move to a new place of work, even if they expect a higher wage there. Their liquidity constraints are aggravated (sometimes strategically) by the payment of wages in kind and in social benefits, and by wage arrears. Many large enterprises have inherited various social assets. Some enterprises prefer to pay wages in the form of social benefits (such as housing, healthcare, recreation, catering, etc.) rather than in cash in order to limit the mobility of workers and to exploit the fact that the worker is unable to move.

To establish and run a new business is also much harder in the NIS than in CEE. Small businesses in CEE face tough competition. In the NIS, however, the problem is more the government's predatory behavior. Small businesses are taxed and regulated at exorbitant rates. In order to survive, they hide all or some of their revenues and become part of the unofficial economy. Once in the unofficial economy, the firm can no longer ask the state for contract enforcement and protection. These services are provided by corrupt bureaucrats and organized crime, which extracts high rents. This dichotomy explains why small business growth is so different in CEE and the NIS. In a competitive world, investment that significantly reduces marginal cost is profitable and therefore will be undertaken. In the NIS, however, the fruits of the investment will be expropriated by rent-seekers. Also, investment and growth make a firm more visible, less mobile and, therefore, more vulnerable to bribery and extortion.

One of the important lessons of economic transition in the NIS is that privatization does not necessarily result in restructuring. There are two sets of problems that impede the restructuring of privatized firms in the NIS. First, due to soft budget constraints and poor corporate governance, firm managers often do not maximize profits. Outside investors cannot effectively control managers. But restructuring requires a certain amount of investment. Without external finance, firms can only rely on the reinvestment of profits, which are rather low precisely be-cause of the lack of restructuring. 
The second problem is the lack of competition and openness in the NIS. Firms in CEE economies can compete in export markets. Due to the huge distances and the high degree of asset specificity inherited from the Soviet industrial structure, many firms in the NIS are locked into a pre-reform customer base. The costs of restructuring are extremely high.

Another barrier to restructuring is political pressure. Since restructuring results in an (at least temporary) increase in unemployment, both federal and local politicians are interested in delaying restructuring and may allocate explicit or implicit subsidies and benefits to managers to preserve excess employment. (Certainly, this pressure exists in CEE economies as well, but it is much weaker because of the openness. Moreover, forthcoming $\mathrm{EU}$ accession provides an end-game benchmark for any projectionist policies.)

Is there any light at the end of the tunnel? The 1998 devaluation has given Russian firms a unique chance to compete in export markets and in the domestic markets that were previously dominated by imports. It is evident that firms have taken advantage of this opportunity, not only by increasing sales at unprecedented rates but also by using some of the revenues for structural changes. For the first time since 1991, the share of barter in inter-firm transactions has showed a clear tendency to decline. But it is still too early to judge whether the vicious circle of survival without restructuring has been broken. 


\section{Introduction}

The theme of this paper is the microeconomics of economic growth in Central and Eastern Europe (CEE) and the Newly Independent States (NIS) over the period 1950-2000. In this region, however, there is a marked structural change that results from the end of the socialist regime in 1989 and 1992, and the subsequent attempt at transition to a market economy. Consequently, the focus of analysis will necessarily be on the nature of the growth process in the transition.

Although there is considerable variation in growth performance within the sub-regions of CEE and NIS, it is apparent from the data that the primary difference is across these two regions (see [20]). Especially with regard to economic restructuring of enterprises, the CEE and NIS look very different. ${ }^{1}$ Explaining the contrasts in performance along this dimension is an over-riding goal of the paper.

This paper studies the behavioral responses to constraints that arise in relation to the major actors in transition economies: households and enterprises. ${ }^{2}$ We look at the households' decisions to save, to supply labor and to accumulate human capital. We study development of new firms and restructuring of existing ones.

The paper is constructed as follows. Section 2 reviews the most important features of growth before the transition and discusses the key legacies that the transition economies inherited from the Soviet growth model. Section 3 sets out possible microeconomic components of economic growth in transition economies, namely, the restructuring of existing firms' and new firm formation as well as households saving and labor supply decisions. Section 4 discusses the behavior of households. Section 5 studies firm restructuring and Section 6 looks at new firm formation. Section 7 concludes.

\section{The Soviet Growth Model}

The growth performance in transition cannot be fully understood without an analysis of the legacies of the planned economy. Our concern is with those legacies that impact on the microeconomic aspects of the growth process. We begin by

\footnotetext{
${ }^{1}$ The extent to which Bulgaria and especially Romania look more like NIS than CEE is an important issue. It is also interesting to note that Poland is the leading CEE with respect to new entry, but that its solution to the dilemma of state enterprises lags behind.

${ }^{2}$ The scope of the paper is the microeconomics of growth. We take the constraints the firms and households face as given. See [44] for an account of development of markets in transition economies and [22] for a discussion of choice of economic policies in transition economies.
} 


\begin{tabular}{|l|r|r|r|r|}
\hline & $\begin{array}{l}\text { Population } \\
1997,000\end{array}$ & $\begin{array}{l}\text { GDP per } \\
\text { capita 1997, } \\
\text { PPP (USD \$) }\end{array}$ & $\begin{array}{l}\text { Average } \\
\text { growth rate } \\
\text { in 1991-97 }\end{array}$ & $\begin{array}{l}\text { Average } \\
\text { growth rate } \\
\text { in 1989-97 }\end{array}$ \\
\hline Armenia & 3,787 & 2360 & $-10,6 \%$ & N/A \\
\hline Azerbaijan & 7,600 & 1550 & $-13,0 \%$ & $-12,1 \%$ \\
\hline Belarus & 10,267 & 4850 & $-4,3 \%$ & $-2,8 \%$ \\
\hline $\begin{array}{l}\text { Bosnia and } \\
\text { Herzegovina }\end{array}$ & 2,346 & $\mathrm{~N} / \mathrm{A}$ & $\mathrm{N} / \mathrm{A}$ & $\mathrm{N} / \mathrm{A}$ \\
\hline Bulgaria & 8,312 & 4010 & $-4,3 \%$ & $-4,8 \%$ \\
\hline Croatia & 4,768 & $\mathrm{~N} / \mathrm{A}$ & $\mathrm{N} / \mathrm{A}$ & $\mathrm{N} / \mathrm{A}$ \\
\hline Czech Republic & 10,304 & 10510 & $-1,3 \%$ & $-0,7 \%$ \\
\hline Estonia & 1,458 & 5240 & $-3,4 \%$ & $-3,1 \%$ \\
\hline Georgia & 5,427 & 1960 & $-15,0 \%$ & $-14,1 \%$ \\
\hline Hungary & 10,155 & 7200 & $-0,9 \%$ & $-1,0 \%$ \\
\hline Kazakhstan & 15,801 & 3560 & $-7,0 \%$ & $-6,1 \%$ \\
\hline Kyrgyz Republic & 4,635 & 2250 & $-7,7 \%$ & $-5,1 \%$ \\
\hline Latvia & 2,465 & 3940 & $-8,3 \%$ & $-6,1 \%$ \\
\hline Lithuania & 3,706 & 4220 & $-6,1 \%$ & $-3,5 \%$ \\
\hline Macedonia, FYR & 1,997 & 3210 & $\mathrm{~N} / \mathrm{A}$ & $\mathrm{N} / \mathrm{A}$ \\
\hline Moldova & 4,312 & 1500 & $-13,4 \%$ & $-10,0 \%$ \\
\hline Poland & 38,650 & 6520 & $3,4 \%$ & $1,3 \%$ \\
\hline Romania & 22,554 & 4310 & $-1,9 \%$ & $-2,8 \%$ \\
\hline Russian Federation & 147,307 & 4370 & $-6,9 \%$ & $\mathrm{~N} / \mathrm{A}$ \\
\hline Slovak Republic & 5,383 & 7910 & $-0,3 \%$ & $-0,4 \%$ \\
\hline Slovenia & 1,986 & 11800 & $0,6 \%$ & $\mathrm{~N} / \mathrm{A}$ \\
\hline Tajikistan & 6,017 & $\mathrm{~N} / \mathrm{A}$ & $\mathrm{N} / \mathrm{A}$ & $\mathrm{N} / \mathrm{A}$ \\
\hline Turkmenistan & 4,658 & $\mathrm{~N} / \mathrm{A}$ & $\mathrm{N} / \mathrm{A}$ & $\mathrm{N} / \mathrm{A}$ \\
\hline Ukraine & 50,698 & 2190 & $-11,8 \%$ & $-9,6 \%$ \\
\hline Uzbekistan & 23,667 & $\mathrm{~N} / \mathrm{A}$ & $-1,8 \%$ & $-0,9 \%$ \\
\hline Yugoslavia, FR & 10,614 & $\mathrm{~N} / \mathrm{A}$ & $\mathrm{N} / \mathrm{A}$ & $\mathrm{N} / \mathrm{A}$ \\
\hline (Serbia/Montenegro) & & & & \\
\hline & & & & \\
\hline
\end{tabular}

Figure 1.1: Selected indicators for NIS and CEE countries. 
looking at the main features of growth in the Soviet-type economies (STEs). These features - dubbed the Soviet Growth Model (SGM) - were applied in various forms in all the socialist economies. We then explain why rapid rates of economic growth, observed initially in all planned economies, eventually slowed down. We will then identify the key legacies inherited from the Soviet period which may influence microeconomics of growth in transition.

\subsection{The Soviet Growth Model}

The Soviet Growth Model (SGM) is a mechanism for extensive growth, that is, growth via the accumulation of inputs rather than through more efficient use of inputs. Resources, human and physical, are mobilized to that task via a system of central planning.

The SGM was effective, if we ignore for the moment the cost, at rapidly industrializing the Soviet economy and other planned economies. In the Soviet case, a predominantly agricultural economy became, in less than three generations, an industrial power, at least when measured by gross production of autos, cement, oil, and steel. In Central Europe the SGM was imposed - to varying degrees - on economies that had already started to industrialize - in Czechoslovakia, Hungary, the GDR, for example - and in countries that were relatively less developed (e.g., Bulgaria and Romania). Over time, however, the performance of the SGM began to steadily decline. Although the exact timing of this decline varies depending on how output is measured, the steady decline was evidenced throughout the region. This is evident in figure 2.1 which uses official data on output growth. Although this clearly overstates the absolute growth rate the downward trend in performance is unmistakable.

Growth rates of output per worker decreased from 5.8\% from 1950-59 to $2.1 \%$ in the 1970's and $1.4 \%$ in the 1990's [35]. This was due to a noticeable deterioration in productivity growth, which turned negative in the 1960's and remained so till the end of the regime. ${ }^{3}$

\footnotetext{
${ }^{3}$ There is an important question of interpretation involved here. If one assumes that labor and capital could be freely substituted, then estimates of total factor productivity are as stated in the text. If one assumes, following Weitzman, that such substitution is costly, then total factor productivity growth does not become negative. Rather the slowdown in Soviet growth is explained by more rapid growth of capital inputs compared with labor, resulting in reduced output growth due to the inability to substitute inputs. Much debate has centered on which interpretation is correct [see [94] and [35], for example], but both explanations are consistent with the defects we discuss.
} 


\begin{tabular}{rrrrrrrr}
\hline \multicolumn{7}{c}{ German } \\
& Democratic & & & & \\
& Bulgaria & Czechoslovakia & Republic & Hungary & Poland & Romania & USSR \\
\hline $1951-55$ & 12.2 & 8.1 & 13.2 & 5.7 & 8.6 & 14.2 & 11.3 \\
$1956-60$ & 9.6 & 7.0 & 7.4 & 6.0 & 6.6 & 6.6 & 9.2 \\
$1961-65$ & 6.6 & 1.9 & 3.5 & 4.5 & 6.2 & 9.1 & 5.7 \\
$1966-70$ & 8.7 & 6.9 & 5.0 & 6.7 & 5.9 & 7.7 & 7.1 \\
$1971-75$ & 7.9 & 5.7 & 5.4 & 6.3 & 9.7 & 11.3 & 5.1 \\
$1976-80$ & 6.1 & 3.7 & 4.1 & 2.8 & 1.2 & 7.2 & 3.7 \\
$1981-85$ & 3.7 & 1.8 & 4.5 & 1.4 & -0.8 & 4.4 & 3.2 \\
$1986-90$ & -0.5 & 1.0 & -1.8 & -0.5 & -0.5 & -3.5 & 1.3 \\
\hline
\end{tabular}

Figure 2.1: Growth in Net Material Product in Selected Planned Economies. source: [87]

Our focus in this paper is microeconomic aspects of growth, hence in this section we consider microeconomic defects of the SGM in order to understand the growth slowdown. In particular, we want to explore microeconomic causes of the extensive growth trap. The extensive growth trap arises because over time it becomes more and more difficult to mobilize resources. Extensive growth requires high input growth. In the early stages of industrialization high input growth can be achieved by shifting labor from traditional sectors, e.g., the countryside, to the modern sector. High growth in the labor force can be achieved by moving people from agriculture to industry. But as this reserve is used up, labor force participation reaches an upper limit. After that, labor force growth is constrained by fertility. One can still accumulate capital at a high rate, but now the capitallabor ratio will rise, and if this causes the marginal product of capital to fall, then the growth of output will lag. ${ }^{4}$ This is the extensive growth trap. ${ }^{5}$

\footnotetext{
${ }^{4}$ Ignoring growth in technical progress (since we are considering extensive growth), per-capita output growth can be written as $\frac{d y}{y}=F_{k} \frac{k}{y} \frac{d k}{k}$ where $y$ is per-capita output, $k$ is capital per worker, and $F_{k}$ is the marginal product of capital. Extensive growth means that the capitaloutput ratio is increasing with growth in $k$. The effect of this on growth thus depends on what happens to $F_{k}$. The key issue is whether the marginal product of capital decreases faster than the capital's share in income increases. If the elasticity of substitution between capital and labor is low, then the marginal product of capital will fall rapidly as capital is substituted for labor. Later on, we will address the issue of low elasticity of substitution.

${ }^{5}$ To see the problem with sustained extensive growth, note that $\frac{I}{K}=\frac{I}{Y} \frac{Y}{K}$, where $I$ is investment, $Y$ is output, and $K$ is the capital stock. Extensive growth implies that capital grows
} 
The extensive growth trap resulted, in part, from the key success of the SGM, its success at mobilization. The SGM is best suited to mobilizing resources. So the key to industrialization is seen in the growth of heavy industry. Now this model may have been effective when the level of terror was high. As socialism develops, however, it becomes more and more difficult to maintain such forced industrialization. Consumption cannot be deferred. But when growth is not achieved through forced industrialization it must be achieved through intensive means, primarily via technical change. This the Soviet economy was ill-suited for; instead the SGM fell victim to the extensive growth trap.

A critical question is why it proved so difficult to escape the extensive growth trap. One explanation, of course, is that in a STE there is no self-correcting mechanism, as in a market economy. ${ }^{6}$ In a market economy if investments are earning inadequate rates of return, capital flows elsewhere. In the STE, however, investment continued to go into activities where the rates of return were very low. This points to a fundamental problem with planned economies, the absence of a market for capital. One of the distinguishing features of socialism was precisely the elimination of private ownership of capital.

The fundamental point is that while STE's managed to invest increasingly greater shares of income, the investments were of poor quality because of the informational problems in the economy and the lack of incentives for efficient investment. The public was forced (savings were not voluntary, of course) to postpone consumption for the future, but these resources were invested so poorly

faster than income, so $\frac{Y}{K}$ must be decreasing over time (CIA recalculations of Soviet national income show the capital-output ratio rising four-fold between 1928 and 1987, while official data shows it almost tripling between 1958 and 1987, see [94] and [35]). Thus for constant growth rates of the capital stock the investment-output ratio must rise continuously. This is the essence of the trap. Extensive growth causes the capital-output ratio to rise, so to maintain growth rates, growth must become even more extensive. Of course, the problem is not quite that stark, because as an economy develops the relative (shadow) price of investment goods decreases over time. So some accumulation of machines can occur without $\frac{I}{Y}$ rising due to the relative price adjustment. But once this price change has been absorbed, further extensive growth can only take place by devoting higher and higher proportions of income for investment. Thus the ratio of $\frac{I}{Y}$ stood at around $14 \%$ in 1950 , rising to $33 \%$ by 1980 . Nonetheless growth rates of per-capita income declined during this period (see [94]).

${ }^{6}$ This is perhaps a key difference between the Soviet Union and the NIC's. As [114] argues, East Asian growth has also largely relied on the factor accumulation, rather than on outstanding total factor productivity performance. However, the East Asian countries seem to have avoided the extensive growth trap. In the NIC's the market may prevent investment from flowing to uses where the marginal product of capital is low. See [85] for a comparison of Soviet and East Asian growth models. 
that no positive return was earned.

Note that extensive growth also meant that enterprises used resources inefficiently. Energy was underpriced and over-utilized. The same is true for other primary commodities. The implication of this is that when prices are liberalized many industries are producing negative value added: the value of output is less than the value of the inputs used in production. ${ }^{7}$ This is fundamentally a pricing problem. The capital was invested in technologies that were highly energyintensive that would only be profitable under the distorted prices. We will discuss the implications when we come to price liberalization.

\subsection{Microeconomic Aspects of the Soviet Growth Model}

There are several institutional features of the SGM that must be highlighted to emphasize the contrast with market economies.

\subsubsection{Enterprises}

Enterprises in the SGM were motivated by plan fulfillment. Bonuses and career paths depended on producing output in accord with the plan. Because plans were generally taut, output plans superceded all other considerations. Although plans contained indicators for quality, cost, technical improvement, etc., these considerations were not binding.

Another key characteristic of planning was that information flows were primarily vertical rather than horizontal. ${ }^{8}$ Although more true of the formal design than actual practice, the interaction between enterprises was organized by superior planning bodies. An important implication of the administrative, or bureaucratic, coordination mechanism in the STE is that enterprises were heavily dependent on personal relationships. ${ }^{9}$ Exchanges in the planned economy were predicated on the identity of the transactors rather than the actual details themselves. The emphasis on idiosyncratic exchange is just the opposite of "arm's length transactions" that are thought to be central to market economies.

\footnotetext{
${ }^{7}$ In 1935 Hayek had already noted that: "The best tractor factory may not be an asset, and the capital invested in it is a sheer loss, if the labour which the tractor replaces is cheaper than the cost of the material and labour which goes to make a tractor, plus interest" [64].

${ }^{8}$ See [66] for a discussion of the formal and informal organization of the Soviet-type economy.

${ }^{9}$ See [54, chapter 2] for a discussion of relational capital, its origin in the planned economy and its revelance in the Russian transition.
} 


\subsubsection{Price System}

Prices in the planned economy were administratively determined and typically remained stable for long periods of time. This aided the process of planning, but obviously negated the allocation role of prices. This was tolerable in the planning regime because prices were primarily used to monitor enterprise transactions. As explained above (section 2.2.1) inter-enterprise transactions were organized from above. Planning of inter-enterprise flows was primarily conducted based on the "achieved level" (which of course created the celebrated ratchet effect).

Producer prices in the STE's were set primarily on the basis of "socially necessary costs." In effect, this meant that costs were based on average, rather than marginal, cost. ${ }^{10}$ An important consequence was that land rent and rental rates for capital were not included in costs of production. At the same time, prices were often set to encourage certain types of behavior: for example, low prices for modern agricultural machinery to encourage diffusion [83, 150]. Prices also differed according the user. The same output would have a higher price when shipped to consumer goods industries compared with defense and heavy industry.

An important consequence of the socialist price mechanism was that it hid the true sectoral production of value added in the economy. ${ }^{11}$ Industry and manufacturing appeared to generate a larger share of value added than was actually the case. This was especially true in the Soviet Union, where the extent to which value added was generated by the raw materials - especially energy - sector was hidden from view. Soviet pricing thus created a distorted picture of the actual economy. Moreover, the nature and extent of these distortions would only be revealed after liberalization.

\footnotetext{
${ }^{10}$ In the command economy, "the relevant cost has had to be average cost for the industry, rather than marginal cost or average cost of the marginal firm. After all, with the establishment of the command economy the chief function of wholesale prices became the 'accounting' (uchetnaia) function, i.e., planning and controlling the financial flows of the enterprise and the branch. For this purpose, industry average cost is clearly suited better than the other two kinds of cost" [60, 135].

${ }^{11}$ The implications of Soviet pricing on the perceived structure of the economy is examined extensively in a recent study by Richard Ericson [39]. He shows how the input-output tables of the Soviet economy - which appeared to provide a consistent picture of the underlying structure - could appear to describe an economy where sectors are able to cover average cost when in fact they do not. The fundamental factor, of course, is pricing that is not based on scarcity. Since prices were based on costs and costs were measured arbitrarily, there was a "circularity in definition" as Ericson calls it, one that could not be eliminated within the structure of the Soviet system.
} 
A related implication of the socialist price mechanism was that it created artificial returns to specific activities. From the standpoint of the leadership, the returns to specific assets were irrelevant, since they (or "the State") owned all property anyway. But with the onset of transition, the distorted picture of relative productivities would be a serious problem. Economic liberalization - freedom to set prices based on supply and demand and free consumer and producer choice - began to unmask the true relative efficiencies of various activities and pointed to their true viability. It showed the extent to which the Soviet-type economy had been producing the "wrong things in the wrong way." Many sectors that had appeared to be value-creating turned out to be value-destroying. ${ }^{12}$ In the case of the former Soviet Union, price liberalization revealed the extent to which value added was really created in the energy and raw materials sector. For many people, however, it had the effect of making reform appear to be the destroyer of the manufacturing sector. ${ }^{13}$

\subsubsection{Labor Supply}

The allocation of labor in the planning system was centrally controlled on the demand side but primarily market-driven on the supply side. ${ }^{14}$ The direct allocation of labor to tasks was rare. ${ }^{15}$ Instead relative wages (inclusive of generous fringe benefits) were used to induce labor to flow to high priority occupations [58].

Unemployment in planned economies as kept low was a product of over-full employment planning. There is some controversy concerning whether this is due to a policy preference of the leadership for full employment [58] or a consequence of soft-budget constraints [83]. Of course, low unemployment was achieved at the expense of high levels of underemployment, with its attendant consequences for economic efficiency. The critical implication for households, however, was that income risk due to forced job separation was rare compared with market economies. ${ }^{16}$

\footnotetext{
${ }^{12}$ This effect was magnified by the decision to open up transition economies to the world market, thus imposing world prices as the new standard of value. Once domestic prices moved to market-clearing levels, many industrial enterprises could not cover costs. Raising prices only led to unsold output.

${ }^{13}$ The argument sometimes goes as far as blaming the reforms for deindustrialization of the economy and degradation of the society.

${ }^{14}$ See [58, chapter 2] for a discussion of the Soviet labor market as a market.

${ }^{15}$ The major exception was prison labor, of course.

${ }^{16}$ Although voluntary separations were not all that uncommon. In the Soviet Union quits rates were on the same order of magnitude as the UK or Germany, though less than in the
} 


\begin{tabular}{lcccc}
\hline & 1960 & 1970 & 1980 & 1985 \\
\hline Socialist Countries & & & & \\
Bulgaria & 83.4 & 88.5 & 92.5 & 93.3 \\
Czechoslovakia & 67.3 & 79.9 & 91.3 & 92.4 \\
East Germany & 72.7 & 79.1 & 83.6 & 86.1 \\
Hungary & 51.8 & 69.4 & 83.2 & 84.7 \\
Poland & 69.1 & 79.5 & 83.2 & 84.7 \\
Romania & 76.4 & 79.5 & 83.1 & 85.1 \\
Soviet Union & 77.9 & 93.2 & 96.9 & 96.8 \\
North European & & & & \\
Countries & & & & \\
West European & 39.9 & 53.8 & 69.9 & 71.1 \\
Countries & & & & \\
South European & 39.5 & 46.4 & 55.1 & 55.6 \\
Countries & & & & \\
\hline \hline
\end{tabular}

source: Kornai (1992: 207).

Figure 2.2: Labor Force Participation of Women in the Age Group 40-44.

Another peculiar feature of Soviet labor markets was the very high laborforce participation rate of women (figure 2.2) compared with market economies. As discussed in [95, 18-20], it is hard to explain these high rates using economic variables alone. This suggests that systemic features of the system generated such high rates - an implication that gained support as labor-force participation rates for women declined during transition.

\subsubsection{Households}

The absence of private property in planned economies eliminated an important source of income variation. It is not surprising that income distribution was more equal under socialism than capitalism. What is more important for our purposes, however, is the observation about collective consumption: that is, consumption

United States [58, 16-17]. The workers were allowed to change job but were not encouraged staying unemployed. Moreover, the Soviet Criminal Code contained an article that prosecuted tuneyadstvo ('idleness').[29] 
financed by the state budget. Although collective consumption as a share of GDP was not much higher under socialism than capitalism $[83,314],{ }^{17}$ there was one critical difference. If we take the share of collective consumption that could be distributed through markets - e.g. pharmaceuticals - and compare this to total consumption (collective plus individual), this share is much higher in the socialist countries. Thus, for 1969 this share was $49 \%$ in the East Germany, $44.2 \%$ in Poland, and $48.9 \%$ in the Soviet Union, while in France the ratio was $15.1 \%$, in Italy $18.0 \%$, and Switzerland $30.7 \%$ [83, 314]. This difference reflects the paternalistic character of the socialist economy.

It is important to note that much collective consumption under socialism was provided by the enterprise. This is true for housing, clinics, cafeteria, sanatoria. When combined with the job security provided by the enterprise the social nature of this organization comes into view. This is an important element to keep in mind when we turn to transition. The enterprise in the Soviet-type system was more than just an economic unit. This means that reforming it will be more complicated than simply changing the ownership structure.

The importance of the enterprise in providing collective consumption will also feature in our discussion of labor markets under transition. This heritage of nonpecuniary compensation continues to some extent under transition and is a feature that reduces job mobility and increases the social cost of enterprise restructuring.

\subsection{Key Legacies from Soviet Period}

The legacy of the Soviet experience is that of an inefficient economic system. These inefficiencies are myriad, but we can consider three main types: those that are internal to organizations; those that are external in the sense of misallocation of resources, and; those that are dynamic.

\subsubsection{Internal Inefficiency}

When considering the microeconomic aspects of growth one should pay special attention to internal inefficiency. One might argue that allocative inefficiency due to the absence of a proper price mechanism - was the key problem of the planned economy, but from the microeconomic perspective the poor incentive structure of the STE must be emphasized. The primary responsibility of the

\footnotetext{
${ }^{17}$ For example, with respect to provision of education, health, welfare spending, socialist countries were not that much different from capitalist countries, especially European ones.
} 
enterprise was plan fulfillment not profit maximization. Enterprise directors that were successful were those that found ways to fulfill the plan. Producing a better mousetrap, or finding a method of producing a mousetrap at a lower cost was not rewarded. ${ }^{18}$ The emphasis on plan fulfillment came at the expense of cost minimization and innovation. ${ }^{19}$ Reducing costs was not important to the director of a Soviet enterprise. This could risk plan fulfillment, and any gains would be taxed away anyway.

\subsubsection{External Inefficiency}

We use the term external inefficiency to refer to problems external to the enterprise. The most basic cause of external inefficiency in the planned economy is allocative inefficiency that results from an ineffective price mechanism. Similarly, the absence of a capital market led to inefficient use of capital across industries. As these problems are well-known we focus on two additional problems, industrial structure and distribution.

Industrial Structure The industrial structure transition economies inherited from the Soviet system has important characteristics that affect transition: an emphasis on size and an absence of small enterprises. Stalinist planners emphasized gigantic plants, known as gigantomania. ${ }^{20}$ As one observer put it: "In the socialist countries, large size and economic efficiency were thought to be synonymous [38, 293]." Plants were often extremely large. Indeed, according to [38] average enterprise size in Hungary and Poland was greater than in large capitalist economies. The difference in size is consistent across sectors, as indicated in figure 2.3 .

One reason for this is that enterprises in the STE tended to be located in a single area, whereas large western companies tend to have plants dispersed geographically. This tendency has led to significant geographical concentration

\footnotetext{
${ }^{18}$ Indeed, the system biased against such efforts, as any gains would be taxed away via the ratchet, while the costs of achieving such gains would fall on the director.

${ }^{19}$ The argument of [103] is that socialist enterprises were inefficient because of government intervention. That is, planners induced the enterprise to undertake activities that they would not otherwise do. One example would be overmanning of enterprises.

${ }^{20}$ As Wiles noted: "There is something 'socialist' and 'progressive' about mere size, even if unaccompanied by lower costs. Gigantomania as such, then, reinforces the view that large capital expenditures are a good thing, even where smaller ones will do" [112, 304]
} 


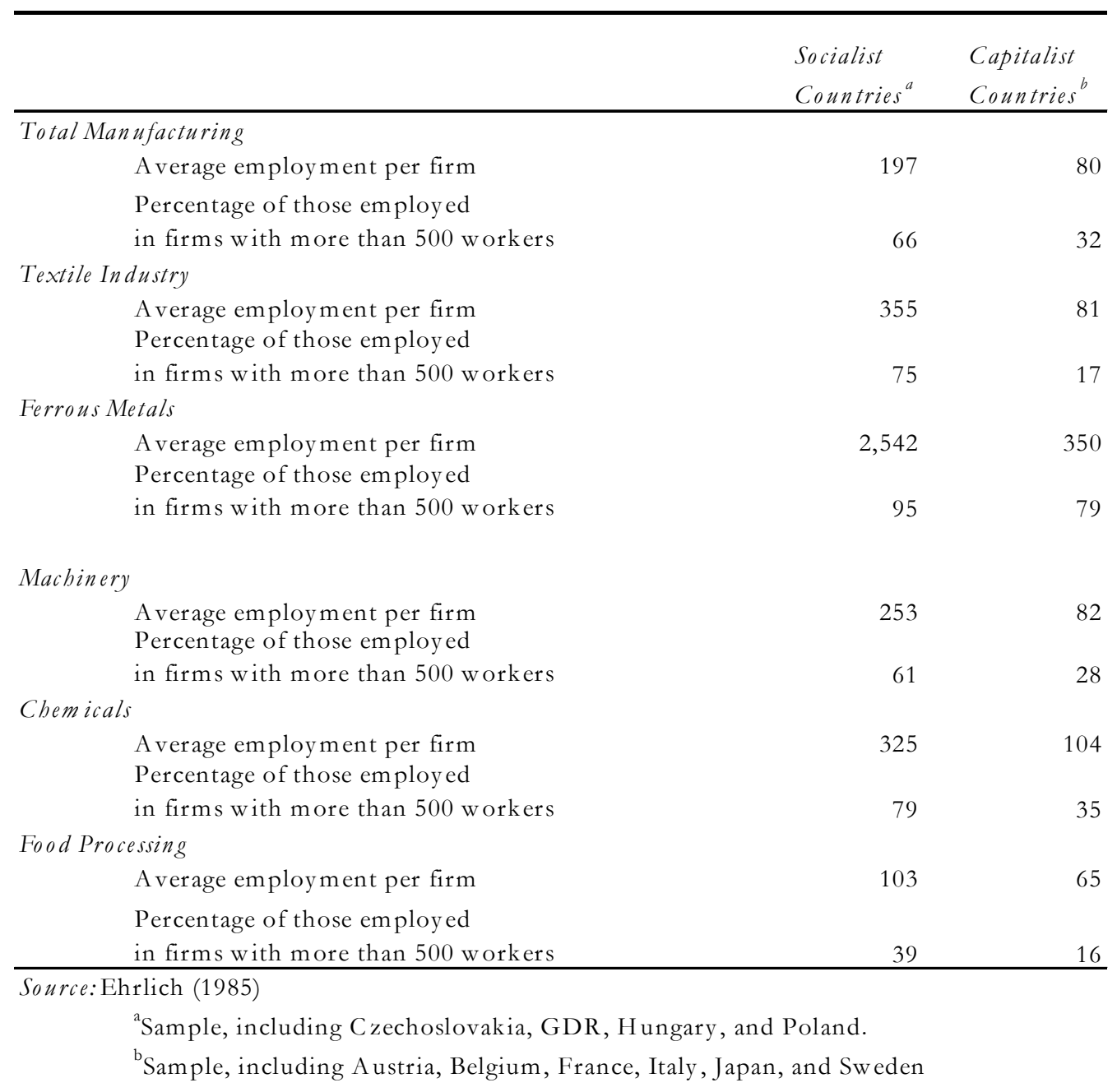

Figure 2.3: Size Distribution of Industrial Firms: International Comparison, 1970. 
of industry. This is especially true in the Russian economy which is much more regionally specialized than western economies, including the United States.

While the extent to which enterprises in the Soviet Union and other transition economies were excessive in size has often been exaggerated in the literature,[16] what is critical is that small enterprises were missing from the landscape. It is interesting, for example, to compare the size distribution of industry in Russia with that of the Unites States. ${ }^{21}$ In the latter most employment is concentrated in small firms (less than 250 workers) or in very large firms (greater than 10,000 workers). These enterprises comprised two-thirds of industrial employment in the US compared with only $25 \%$ in Russia. Russia has both less extra large firms and less small firms. Most striking is the difference with respect to small firms, where in Russia 91.5 percent of civilian employment and an estimated 94.5 percent of total (i.e., including defense) employment in manufacturing is provided by enterprises with employment of 250 or greater, while only 73.1 percent of US. manufacturing employment is provided by similar firms.

The lack of small enterprises in the Soviet economy no doubt was an important factor inhibiting innovation and technical change. New ideas often are developed in new firms, and most new firms start out small. The absence of the dynamism created by small firms may be an important element in the deterioration of performance in the Soviet economy.

In addition to the absence of small firms in the Soviet economy it is usually asserted that Russia suffers from a monopoly problem. This is less of a problem than is usually recognized, however. As is shown in [16], Russian industry is not that highly concentrated. While Russia has many concentrated industries these tend to be small and account for a small proportion of employment. Most employment takes place in sectors that are not highly concentrated.

The other aspect of the industrial structure that has impacted on economic performance is the relatively closed nature of the economy. Although STE's engaged in trade both within and outside the socialist bloc, enterprises were quarantined from the effects of external shocks. Trade was conducted through foreign trade ministries. This provided for a separation of domestic and foreign prices. Moreover, trade was viewed primarily as a means of obtaining inputs that could not be produced domestically. Exports were viewed as a cost because it meant that less of the particular output was available to meet domestic demand. Hence, there has always been political pressure to achieve self-sufficiency which of course

\footnotetext{
${ }^{21}$ This section follows [16]. The comparison is made using the 1987 census of manufacturing for the US, and the 1989 Soviet census of industry for Russia.
} 
encourage investment into inefficient enterprises that are not competitive in the world economy.

Distribution and Supply Perhaps one of most important legacies of central planning is the rigid supply and distribution system. State systems of distribution and supply were common throughout the region, with the exception of Hungary under the NEM, and replaced the traditional intra-firm relations common in market economies. These rigid supply networks result in market segmentation.

Although all STE's suffered from ineffective distribution systems, these problems were exacerbated in the former Soviet Union (FSU) due to its sheer size. Location decisions in the Soviet Union were made without sufficient attention paid to costs. Moreover, the distribution system was centrally organized and Moscow-centric.

The essential feature of Russian industrial structure, then, is that potential competition is inhibited by poor transportation infrastructure. ${ }^{22}$ Russia is, after all, a very large country, and the transportation and distribution system inherited from the Soviet period was not designed to create national markets. Moreover, the underdevelopment of the financial and legal system serve as entry barriers. These supporting institutions (distribution, finance, law, and transportation) may much more important to developing competition as any technological barriers (i.e., economies of scale). Although the potential for competition to develop through changing product lines and new entry appears significant, the inadequacy of these supporting institutions may prove to be a significant barrier to effective competition for years to come.

These problems are aggravated by the above mentioned market concentration. In STE's small firms were absent not only in manufacturing but also in the trade sector. The transition economies have inherited monopolized distribution system which constrained firm's choice of new suppliers and new customers.

Many of these problems impact NIS economies more that CEE ones. The reasons are multiple. First, the geography is more favorable in CEE: the distances are shorter so that transportation is cheaper. Second, the CEE economies are more open being closer to the West and suffering less from the self-sufficiency ideology.

\footnotetext{
${ }^{22}$ As the authors of the IMF-World Bank-OECD-EBRD joint study on the Soviet economy argued: "Even where more than one enterprise exists, the national aggregates hide a high degree of regional monopoly power that is protected by generally poor communications and transportation and by administered marketing channels which, in turn, are insulated from one another by ministerial lines of responsibility" [71, 16].
} 
Therefore a monopolistic industrial structure is a heavier burden for NIS rather than for CEE.

\subsubsection{Dynamic Inefficiency: Difficulties with Innovation}

The difficulties in fostering and diffusing innovation were central defects of the system. The extensive growth trap was, most specifically, a failure to achieve technical progress. The incentive system of the planned economy worked against innovation. Therefore transition economies have inherited outdated technologies and no infrastructure for adoption and diffusion of innovation.

One factor that accounts for low rates of technical progress was the inability to substitute capital for labor effectively. The elasticity of substitution between labor and capital was very low in STE's. ${ }^{23}$ The question is why? This is a rather deep question, one that points to the heart of the SGM. To some extent it is due to the inability to substitute capital for labor in a functional sense. That is, the enterprise does not shed labor, it just under-employs it, due to an over-full employment system. In STE's the enterprise always wants to hoard as much labor as possible, as a reserve against taut plans. Moreover, enterprises always want to add capital to raise capacity. So additions to the capital stock were utilized inefficiently due to lack of incentives to use inputs in a cost-minimizing manner. More importantly, however, there was a built-in input-output conservatism under planning. Plans were based on previous plans, and this tended to inhibit substitution as well.

A second explanation of the low elasticity of substitution focuses on the absence of organizational innovation. In market economies an important source of productivity growth is the churning of firms as firms expand, contract, enter, and exit. This churning process causes resources to flow to higher valued uses. In STE's this process is absent. Capital is simply poured into existing enterprises; there are no entrepreneurs who are able to re-organize the production process. The allocation of capital across enterprises is considered - if, at all - only in the investment decision. Once capital is in place, it is sunk. Enterprises cannot trade capital or capital services among themselves due to the absence of ownership.

One crucial process for improving resource allocation in market economies is exit. Ceasing operations frees resources for more effective uses. In STE's, there is no mechanism for exit. ${ }^{24}$ Inefficient enterprises do not cease operation. Hence,

\footnotetext{
${ }^{23}$ This was first noted by Weitzman [110]. There has been some dispute about this, however. See [94] for a balanced discussion of the issue.

${ }^{24}$ See [68] for a model of industrial dynamics under the constraint of no exit.
} 
resources are not freed for alternative uses. But that is not the only cost. The absence of exit also influences entry. Groups of workers could not form new establishment; all entry occurs only from above. Since exit was essentially non-existent planners were reluctant to create too many new enterprises. ${ }^{25}$ This exacerbated the static nature of economic organization. It meant the new processes had to compete with old ones within the enterprise rather than across enterprises. This was a significant inhibition to innovation and especially to its diffusion.

That Soviet-type economies were plagued with difficulties in achieving technical progress was recognized quite early on. Discussion of how to accelerate technical progress, so that growth could be achieved intensively was discussed often. ${ }^{26}$ The problem is that the institutional design of the system - especially the structure of incentives — did not support innovation (e.g., [7] and [30]). Indeed, the incentive mechanism often worked to suppress innovation. It is important to understand that the problem was not a lack of discovery. Rather, the problem was the slow diffusion of innovations throughout the economy. ${ }^{27}$

There are a myriad of reasons for the slow rates of diffusion of innovation. Paramount is the problem of incentives based on the current plan fulfillment that is endemic in planned economies. The "virtuous haste" that characterizes Soviet planning imposes costs on potential innovators who would sacrifice current production for future gains. This is critical because the gains from innovation are taxed away by the dynamic incentives problem, the ratchet effect. Better performance resulted in higher plan targets in the next period. The enterprise bears all the risk of innovation but loses the benefits due to the ratchet. Hence, enterprises preferred to add capital but not innovate. This is the reason why the

\footnotetext{
${ }^{25}$ Moreover, recall that an STE is supply constrained, so that there are no free resources available to start up new entities. This means that any new activity is costly in terms of other activities foregone; especially so to the planners.

${ }^{26}$ Compare the following speeches to Party Congresses from G. Malenkov in 1941 and M. Gorbachev in 1986: "...highly valuable inventions and product improvements often lie around for years in the scientific research institutes, laboratories and enterprises, and are not introduced into products." "...many scientific discoveries and important inventions lie around for years, and sometimes decades, without being introduced into practical applications." Quoted in [30, 1105]

${ }^{27}$ It is instructive to examine the diffusion rates for major innovations in the USSR compared with some market economies. For example, oxygen steel was introduced in the USSR in 1956 and the US in 1954. By 1982 oxygen steel accounted for $29.6 \%$ of total steel production in the USSR compared with $62 \%$ for the US. Similarly, numerically controlled machine tools were introduced in the USSR (1965) and Japan (1964) at approximately the same time, yet by 1982 such machines accounted for $16.6 \%$ of total metal-cutting machine tools in the USSR compared with $52.8 \%$ in Japan. See $[30,1108]$ for further details.
} 
diffusion of innovations in the STE was so slow. It is interesting to note that while Stalin was alive, and hence the costs of failing to adopt innovations were higher, ${ }^{28}$ diffusion was more rapid than in later periods.

\subsection{Summary}

We have focused on systemic legacies of the Soviet growth model for the transition process and highlighted instances where systematic differences exist between the NIS and CEE's. Our discussion has been, necessarily, selective. Thus we have not discussed several factors which may, in fact, be important. For example, we have not discussed differences in the organization of agriculture. In some CEE's collectivized agriculture was eliminated long before central planning. This may be an important difference.

Another key difference in legacies between the NIS and CEE's is the extent of defense orientation. The NIS were hypermilitarized [52], and Russia especially so. The legacy of large defense enterprises are a special burden for transition. This is further exacerbated by the fact that many large defense enterprises in the NIS are concentrated in specific geographical areas which makes restructuring especially costly. The difficulty of defense conversion plagues many transition economies, but this is almost certainly a differential burden on the NIS, and especially Russia.

Finally ${ }^{29}$ we might note the special difficulties associated with different resource endowments. The Soviet Union was endowed with abundant natural resources. This endowment has passed to some of the successor states, but not all. Our purpose here is not to discuss the general implications of resource abundance on growth, ${ }^{30}$ but there is an important consequence we should discuss here. Because of energy abundance Soviet enterprises were particularly extensive in their energy use. The low cost of energy encouraged its use. This is a situation that cannot survive liberalization, and as energy prices have moved towards world levels this has rendered many enterprises non-viable. Although this should raise the reward to restructuring, it has also greatly complicated the process. ${ }^{31}$

\footnotetext{
${ }^{28}$ Under Stalin "wreckers" faced a trip to Siberia. In the post-Stalin period the cost of failure was typically reduced to loss of position.

${ }^{29}$ One could also discuss here the implications of breakup. The Soviet Union was an integrated economy that broke into 15 unequal parts. Breakup is not unique to the NIS; Czechoslovakia and Yugoslavia has also divided into multiple successor states. It is doubtful, however, that the latter were as economically integrated as the Soviet Union.

${ }^{30}$ See [44] for a discussion.

${ }^{31}$ See [54] for an analysis of how these specific legacies have complicated transition in Russia.
} 


\section{Microeconomics of Growth in a Transition Process}

\subsection{Growth in transition: the two sub-regimes}

In 1989-92 most countries in the region abandoned the centralized planning and began their transition to a market economy. As Figure 1.1 shows, their performance in the decade that followed has been very different. All countries experience a decline of output in the beginning of transition. ${ }^{32}$ In some of them (mostly in CEE) the decline was rather short and small and was followed by a sustainable turnaround to growth at rates exceeding those of OECD economies. In the others (mostly NIS), however, the decline was long and deep and has not been replaced by a steady recovery.

A critical focus in this paper is to understand the difference in microeconomic response, primarily with regard to restructuring, in CEE and NIS. A rough generalization that we will make is that in the CEE's behavior has responded to changes in the incentives system in a manner consistent with what might be expected from standard analysis. In the NIS, on the other hand, institutional and behavioral adaptation have taken place to circumvent the need to change (survival). One hypothesis is that this is due to the differing legacies from the socialist period in the two regions; especially in terms of competitiveness. It may also be due to increased openness of the CEE's because of geography. ${ }^{33}$

Certainly, there is no clear dividing line between CEE and NIS. The most successful CEE countries are Czech Republic, Hungary and Poland but even within them there are large regional differences. The performance of the Baltic states (Estonia, Latvia and Lithuania) that used to be a part of Soviet Union is much more similar to that of CEE than other NIS (this is may be due to the fact that they joined the USSR only in 1939). In the former Soviet Union, there is also a huge degree of heterogeneity. Even within Russia there are regions that are doing really well even by CEE standards.

Despite all these variations, in the analysis below we will refer to 'typical' CEE and NIS transition experiences as if those two sub-regimes were clearly defined. The two extremes we will have in mind are the Visegrad countries (Czech Republic, Hungary and Poland) and Russia/Ukraine (see Figure 3.1).

Another important issue is the relationship between growth and transition. One would like to determine the extent to which a planned economy must trans-

\footnotetext{
${ }^{32}$ For explanations of the output decline in the beginning of transition, see [12] and [100].

${ }^{33}$ Consistent with the differing responses of the Baltics and Kirghizia.
} 


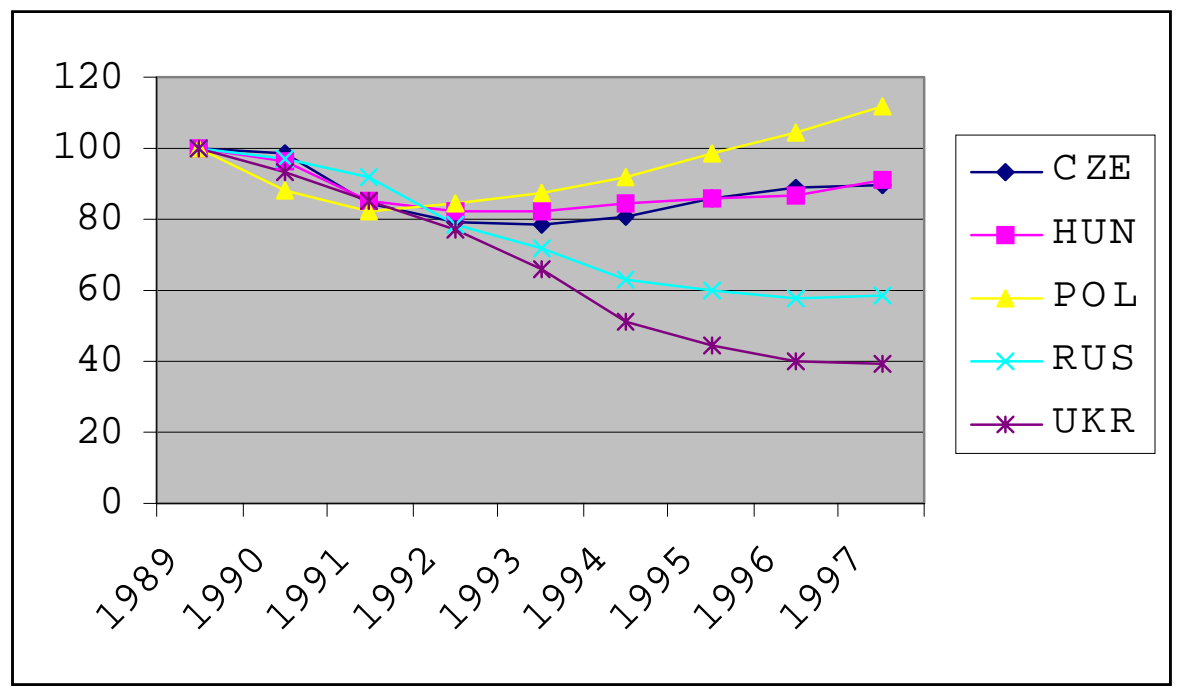

Figure 3.1: GDP per capita in Vysegrad countries, Russia and Ukraine. 1989=100. Source: World Development Indicators, World Bank.

form itself so that it can achieve sustained growth. The question is whether transition is a precondition for growth or a separate process. ${ }^{34}$ It might be argued that the secular decline in growth rates (see figure 2.1) in planned economies demonstrated inability of the SGM to sustain growth. Nonetheless, this does not mean that liberalization and transition are necessary conditions for growth to resume. ${ }^{35}$ For our purposes, however, the important question is whether the microeconomic constraints to growth are affected by transition. Clearly transition has altered the locus of decision-making for key microeconomic activities. Households and firms

\footnotetext{
${ }^{34}$ For example, it could be argued that liberalization enhances static efficiency, and thus increases welfare even if it does not contribute to faster economic growth.

${ }^{35}$ There are, for example, the cases of Uzbekistan and Belarus. Both countries have undertaken very little reform but have clearly outperformed neighboring CIS countries in terms of GDP growth. It is not clear though that the Belarus-Uzbek experience makes a strong case against transition. First, as discussed above, the price system before liberalization was highly distorted and therefore it is hard to compare closed planned economies with liberalized open ones. Second, as [43] argues, the policies pursued by these two countries can only maintain GDP at the prereform levels but cannot sustain long-term growth. Furthermore, [116] shows that the Uzbek growth puzzle can be explained in terms of initial conditions (low degree of industrialization and self-sufficiency in energy) as opposed to policy choices.
} 
must make decisions rather than central planners. In this context it seems likely that transition to the market will be critical to prevent an institutional vacuum that could prevent a recovery of economic growth.

\subsection{The microeconomic challenges of economic transition}

One of the lessons from the transition experience in NIS countries is that the price liberalization, macroeconomic stabilization, open trade and privatization may not be sufficient for a successful transition. The inherited legacies may slow down the development of market institutions which in turn may prevent microeconomic agents from adopting the economic incentives of market economy. The microeconomic agents that act in a transition economy are firms and households. ${ }^{36}$ Economic development requires that households save and accumulate human capital and then supply labor and capital to the emerging firms. The transition is however somewhat different, since the economy has already been industrialized. ${ }^{37}$ The labor force has accumulated many of the necessary technical skills associated with industrialization, and the physical assets are in place. Moreover, firms already exist that resemble modern firms in capitalist economies. Therefore the problems are slightly different. ${ }^{38}$ Many of the most critical issues in transition center around getting appropriate institutions for a market economy.

The basic microeconomic decisions that households make in transition are the same problems dealt with elsewhere: households choose how much to save and in which firms to work; they also may choose to become entrepreneurs and establish new business; existing firms make decisions about restructuring, choices that concern changing both inputs and outputs, and including the size and composition of their workforce. We will go through all these choices to see in which respects CEE and NIS are different and whether this difference can explain the better performance of CEE.

\footnotetext{
${ }^{36}$ It is tempting to consider local governments as microeconomic agents, too, as a large part of recent literature does. Below, we will refer to the role of local governments specifically.

${ }^{37}$ The few exception of Albania, Romania and some Central Asian countries still have many more large industrial enterprises than an typical developing economy.

${ }^{38}$ See $[96]$ for a discussion of the difference between development and transition.
} 


\section{Households}

\subsection{Savings behavior}

Savings are always critical to economic growth, and the need to restructure enterprises from the socialist period intensifies the need for investment. Inflows of capital are one source of resources for this task. These may be critical during the transition process, but long-term growth more likely depends on savings. This follows for two reasons. First, the Feldstein-Horioka results suggest that net capital flows are not all that large[41]. Second, transition economies are as likely to suffer from capital flight as they are to benefit from net inflows. Hence, restructuring and investment will likely depend on domestically generated savings.

\subsubsection{Savings under Socialism}

The extensive growth model required high saving rates. Under socialism most savings were public savings - the profits of socialist enterprise and indirect taxation. Planned economies were able to achieve high rates of capital accumulation via central control over the composition of output between capital and consumption goods. The profits of the enterprises sector were controlled by the center and allocated to enterprises for investment. Capital accumulation under socialism was quite high; the problem was the low efficiency of investment. Many STE's achieved investment rates of over $30 \%$ of GDP, ${ }^{39}$ consistent with the extensive growth strategy that was pursued [94]. These high savings rates were easy to achieve given the controls available under planning. ${ }^{40}$

Household savings in the pre-transition was primarily a response to shortages. ${ }^{41}$ The extensive social safety net reduced the need for private savings. ${ }^{42}$ Moreover, the limited array of assets that could be accumulated by households in

\footnotetext{
${ }^{39}$ Between 1976 and 1981 the ratio of investment to GDP in Romania exceeded 40\%!; this ratio was $37 \%$ in Hungary for the same period. See [67, 211].

${ }^{40}$ It should be noted that pre-transition savings rates may be overstated due to repressed inflation. Artificially high nominal incomes in the presence of price controls leads to high measured savings calculated as a residual. Were the true transactions prices for consumption used to deflate nominal incomes the resulting level of savings would be reduced. This presumably explains why Poland had such a high rate of savings in 1989, a year of incipient hyperinflation.

${ }^{41}$ See [67] for a survey of savings in socialist economies.

${ }^{42}$ Although the need to pay under the table (na levo - "on the left" - in the former Soviet Union) did create the incentive for some private savings.
} 
socialist economies also limited savings. ${ }^{43}$ State savings accounts were the primary vehicle for savings, and these accounts paid very low interest rates.

\subsubsection{Savings in the Transition}

Transition alters the very nature of savings. The rate of capital accumulation is no longer a planning decision. Because consumption was kept artificially low under planning it is not surprising that one initial impact of transition was to see declines in savings rates across the regions. Savings rates in the CEE's averaged around 17 to 18 percent in the mid-1990's, while in the NIS these rates were generally in the low $20 \%$ range $[[113,41]$ and figure 4.1$]$. Presumably this reflected an increase in welfare as a constraint on household choice was lifted. It should be noted, however, that in addition the uncertain environment of early transition afforded poor opportunities for savings aside from capital flight.

We can gain some insight into savings behavior across the region by looking at gross domestic savings. This is derived from the residual of gross domestic investment and the current account balance. While a crude measure, it does provide some information that can be used cross-country. In figure 4.1 we observe that gross savings rates fell with the transition shock before rebounding. This is no doubt related to the sharp, and presumably unexpected, decrease in incomes that was experienced with the onset of transition, combined with the policy decision to alter the composition of output from investment to consumption. The variation in savings rates across economies also increased with transition. It is also evident that savings rates vary more in the NIS than in Central Europe, especially if we exclude Albania. ${ }^{44}$

With transition the locus of savings moves towards the private sector. ${ }^{45}$ Enterprises retain earnings in order to invest, and households save in order to provide for future consumption. Centrally-financed investment declines dramatically with privatization. An important source of motivation for household savings is the increased risk associated with income streams in the post-socialist environment, combined with weak institutions to accomplish consumption smoothing (aside

\footnotetext{
${ }^{43}$ Note, for example, that housing was almost exclusively publicly supplied, and the public transportation was extremely well run leading to less need to save for purchasing a car.

${ }^{44}$ It is clear from the table that a major source of variation in savings is civil war and internal conflict. This is apparent when one considers the cases where negative savings appears, such as Albania, Armenia, Georgia, and Tajikistan.

${ }^{45}$ Although governments still have an impact on total savings via public sector deficits.
} 


\begin{tabular}{lrrrrrr} 
& 1990 & 1991 & 1992 & 1993 & 1994 & 1995 \\
\cline { 2 - 7 } Albania & 0.123 & -0.142 & -0.758 & -0.383 & -0.168 & -0.078 \\
Bulgaria & 0.22 & 0.358 & 0.188 & 0.107 & 0.209 & 0.248 \\
Croatia & $\mathrm{NA}$ & 0.022 & 0.195 & 0.133 & 0.12 & 0.014 \\
Czech Republic & 0.299 & 0.368 & 0.274 & 0.202 & 0.201 & 0.202 \\
Hungary & 0.28 & 0.187 & 0.149 & 0.112 & 0.15 & 0.189 \\
Macedonia, FYR & 0.235 & 0.11 & 0.119 & 0.115 & 0.041 & 0.15 \\
Poland & 0.328 & 0.18 & 0.167 & 0.165 & 0.169 & 0.183 \\
Romania & 0.208 & 0.241 & 0.23 & 0.24 & 0.249 & 0.229 \\
Slovakia & 0.242 & 0.282 & 0.241 & 0.218 & 0.288 & 0.316 \\
Slovenia & 0.326 & 0.274 & 0.265 & 0.206 & 0.226 & 0.213 \\
& & & & & & \\
Average & 0.25 & 0.19 & 0.11 & 0.11 & 0.15 & 0.17 \\
Coefficient of Variation & 0.26 & 0.83 & 2.80 & 1.64 & 0.87 & 0.68 \\
\hline & & & & & & \\
Armenia & 0.358 & 0.205 & -0.198 & -0.037 & -0.192 & -0.199 \\
Azerbaijan & 0.319 & 0.394 & 0.17 & -0.032 & 0.034 & 0.037 \\
Belarus & 0.293 & 0.329 & 0.337 & 0.214 & 0.156 & 0.226 \\
Estonia & 0.223 & 0.345 & 0.297 & 0.235 & 0.178 & 0.25 \\
Georgia & 0.249 & 0.249 & 0.017 & -0.189 & -0.327 & -0.091 \\
Kazakhstan & 0.319 & 0.394 & 0.302 & 0.213 & 0.123 & 0.196 \\
Ky rgizia & 0.04 & 0.14 & 0.079 & 0.04 & 0.14 & 0.1 \\
Lithuania & 0.252 & 0.285 & 0.179 & 0.145 & 0.094 & 0.143 \\
Latvia & 0.388 & 0.435 & 0.481 & 0.254 & 0.195 & 0.2 \\
Moldova & 0.319 & 0.394 & 0.15 & -0.06 & 0 & -0.007 \\
Russia & 0.319 & 0.394 & 0.384 & 0.35 & 0.291 & 0.256 \\
Tajikistan & 0.137 & 0.173 & 0.18 & -0.109 & -0.002 & 0.181 \\
Turkmenistan & 0.319 & 0.394 & 0.21 & 0.2 & 0.14 & 0.12 \\
Ukraine & 0.263 & 0.284 & 0.364 & 0.36 & 0.198 & 0.168 \\
Uzbekistan & 0.157 & 0.236 & 0.338 & 0.159 & 0.244 & 0.2 \\
Average & & & & & \\
Coefficient of Variation & 0.35 & 0.30 & 0.77 & 1.46 & 1.93 & 1.10 \\
\hline & & & & & &
\end{tabular}

source: Denizer and Wolf, 1998b: 6.

Figure 4.1: Gross Domestic Savings as a share of GDP in Transition Economies. 
from intra-family transfers). ${ }^{46}$

The shift in income profiles is an important element in understanding posttransition savings. Income profiles of younger, and highly skilled, households tilt upward, presumably, as lifetime opportunities expand. For older households, however, the income profile tilts in the opposite way. If financial markets were well-developed in transition economies this would reduce savings of the former group financed out of increased savings of the latter. In the circumstances of transition, however, such transfers are limited primarily to intra-family transfers [See Subsection 4.2 below].

The shock of transition led to the destruction of household savings in many transition economies. This was the result of official price inflation combined with interest-rate ceilings that destroyed the real value of savings. Hence, households found themselves at the start of transition with asset stocks below their desired levels. One might suppose that this would lead to increased savings in order to rebuild these stocks. In addition, the increased uncertainty associated with transition as well as inability to borrow in case of negative income shocks might also cause households to increase their target levels of asset stocks.

While the destruction of previous savings may induce households to increase savings there are important forces that work in the opposite direction. First, the negative income shock associated with the output decline in most transition economies should lead to dissaving so that households can maintain their consumption levels. Second, the fact that previous savings was wiped out presumably had an adverse effect on the form that these savings would take. At least in the early stages of transition households were reluctant to trust domestic savings institutions and domestic assets. Savings took the form of holding foreign currency or transferring assets abroad. Savings held in this form are less easily transformed into investments and therefore less useful (available) for growth purposes, ${ }^{47}$ at least until this flight capital returns. ${ }^{48}$

\footnotetext{
${ }^{46}$ The same problem exists in the developing countries: see [23] for discussion of high savings rates of African rural households that have no access to assets for consumption smoothing.

${ }^{47}$ This is especially true for capital flight. Of course, the likelihood that flight capital will return and finance investment is related to the problem of creating a legal and institutional environment conducive to foreign investment. We discuss this below.

${ }^{48}$ Using official data of the Russian balance of payments various observers [3] and [59] estimate that capital flight from Russia was relatively stable before the 1998 meltdown, roughly being about 25-30 bln. per year (one third of total exports or 7 per cent of GDP). After the devaluation in August 1998, capital flight decreased to about $\$ 20$ bln. per year, but because the dollar value of GDP fell, capital flight is now about 10 per cent of GDP. In any event, per capita flight of
} 
In a study of household surveys conducted in Bulgaria, Hungary and Poland [31] analyze savings behavior in the transition period. They find a strong positive relationship between the relative income position of the household and the savings rate. More important, perhaps, controlling for incomes, they find that savings rate is negatively related to education level. ${ }^{49}$

Another factor that may lead to high observed savings rates is the desire to purchase consumer durables. In the pre-transition period stocks of durable goods were low. As households accumulate reserves to purchase consumer durables measured savings - calculated as a residual - increases. But this represents consumption rather than savings. Given that this catchup is common across households from the same starting point (i.e., the start of transition) some overstatement may appear in the data. The survey evidence [31] shows that households owning most standard consumer durables save less. While this could be due to a negative wealth effect, most of their measures of household wealth do not exert a negative effect on savings. This leaves the absence of credit markets as the likely explanation. This also suggests that some observed savings in these economies may be transitory; as households make their durable purchases their savings rates may decline.

A related issue concerns the effect of increased openness on savings. Increased access to global financial markets augments domestic capacity to smooth income fluctuations. External liberalization, especially with regard to financial markets, reduces the need to self-insure; hence, it reduces savings. This increased access is a welfare gain to the economy. But it also means that if the environment for foreign investment is hostile, then investment may be heavily constrained by external liberalization.

Savings behavior may also be affected by the extent and effectiveness of pension reforms that are yet to be implemented in most transition countries (see [44], section 3.3.3 for a discussion of pension reform in Poland). Taking into account all of the abovementioned factors that influence the saving rate one is hard-pressed to forecast what will happen to the long-run equilibrium saving rate in the transition

$\$ 150$ per capita is still much higher than in the other transition and developing economies (as a matter of fact, most CEE economies have positive capital inflows). For alternative estimates of capital flight see [111]. See [55] for quantitative analysis of determinants of capital flows in transition economies.

${ }^{49} \mathrm{It}$ is unclear how to interpret this finding. It could be that households with high education levels unsuited to the market are dissaving due to adverse economic conditions. Alternatively, households with higher education may be experiencing increasing returns to their human capital, and may be increasing consumption in response to higher wealth. 
economies. Yet it is perhaps safe to conclude that given the remarkable levels of capital flight experienced in many of these economies, the supply of savings does not seem to be a binding constraint for economic growth.

\subsection{Intra-family transfers}

Transition has been associated with sharp declines in (at least apparent) real incomes in all countries. Unemployment also became an open phenomenon. Meanwhile, the real benefits to recipients of social transfers also declined sharply. Transition governments typically lack the capacity to protect all those made vulnerable by transition. The consequences for the population thus depends, to a large extent, on the degree to which intra-family transfers can compensate for the absence of public transfers. ${ }^{50}$

The importance of transfers in transition is enhanced by the lack of trust in financial institutions. ${ }^{51}$ Where financial institutions are well-developed households can smooth consumption in the face of idiosyncratic shocks. In the absence of such institutions, intra-family transfers play a larger role. Hence, financial underdevelopment in transition economies has made intra-family borrowing and transfers important. First, intra-family transfers help to cope with poverty. It is one of the explanations of the absence of widespread famine in quite a few NIS countries where more than half of population have incomes below the poverty line. ${ }^{52}$

The importance of family networks in transition economies is suggested by their prominence in the socialist period. Informal activities were essential means for households to cope with the shortages associated with central planning and price controls. A key question for the transition is the capacity of these networks to survive, and to compensate for inadequate public transfers. ${ }^{53} \mathrm{~A}$ study of worker households in Poland [28] found that transfers in 1987 functioned much

\footnotetext{
${ }^{50}$ Informal employment is also an effective coping strategy in transition. The effectiveness of this in Ukraine is discussed in [72].

${ }^{51}$ Our focus is on transfers within a country. Transfers from abroad - remittances - can also play an important role. Estimates for Albania show that the average level of remittances was $\$ 700$ million, which is quite large considering that Albania's GDP in 1996 was about $\$ 2.6$ billion $[84,405]$. One may also consider the role of diaspora populations in the ranks of entrepreneurs. This has been frequently commented on with regard to Poland, but is also very important in Albania [79].

${ }^{52}$ One should bear in mind that climate is worse than in CEE and NIS than in other regions of the world. In particular, housing provided with heating is a necessity.

${ }^{53}$ One can also study the effect of transfers on consumption smoothing in the face of idiosyncratic shocks. See [105].
} 


\begin{tabular}{lccccc}
\hline & $\begin{array}{c}\text { Kyrgyz } \\
\text { Rep }\end{array}$ & Poland & Russia & Vietnam & $\begin{array}{c}\text { United } \\
\text { States } \\
\end{array}$ \\
& (1993) & (1992) & (1993) & (1993) & (1979) \\
\hline Households giving or receiving & 21.0 & 65.0 & 36.0 & 68.0 & 30.0 \\
Transfers as a share of total income & 7.4 & 3.2 & 4.4 & 11.9 & 2.0 \\
Transfers as a share of recipient incor & 41.1 & 7.2 & 20.1 & 27.0 & 6.0 \\
\hline
\end{tabular}

source: World Development Report, 1996: 74.

Figure 4.2: Private Transfers in selected transition economies and the United States (percent of total)

like means-tested public transfers: they flowed from high to low income households, to large families, and to those experiencing illness. Transfers continued to play an important role post transition, but at a reduced level. Transfer levels fell compared with 1987. Thus the role of transfers in alleviating poverty was reduced. ${ }^{54}$ Similar results were obtained for Russia [27].

Some evidence on the magnitude of transfers is given in table 4.2, which show that these can be quite large. As in the Polish case, most of the evidence suggests that transfers are most likely to go towards those households that would be the target of safety nets. It also appears, according to a study for Russia, that if public pensions were eliminated that private transfers would replace $19 \%$ of their amount.

Intra-family transfers play a second important role, in addition to alleviating poverty. Given the underdeveloped contractual environment, and its effects on the financial system, investment in transition economies is typically self-financed. This has consequences for enterprises that we discuss elsewhere. For the creation of new enterprises, self-financing means, essentially, family financing. Hence, intra-family networks can be critical to the process of enterprise formation. ${ }^{55}$

\footnotetext{
${ }^{54} \mathrm{In}[78]$ it is argued that while social transfers in Poland during the 1990's did reduce poverty and income inequality this was not their sole focus. Transfers were also directed to the middle class, and it is argued that this had the effect of reducing the political cost of economic reform.

${ }^{55}$ As shown in [50] and [75] financial constraints tend not to bind for small businesses both in the CEE's and the NIS. The only applicable explanation for this is that entrepreneurs can
} 
Indeed, one can speculate that the reduced role for transfers in the posttransition period may be due to the fact that now there is an additional role for such wealth. The use of savings in new business formation may be the cause of the decline in transfers. In the pre-transition period there were very few outlets for investment. The key test would be to see whether there is a relationship between the reduced level of transfers and the rate of small business formation across the region.

\subsection{Labor mobility}

Labor mobility is crucial for reallocation of resources in transition economies. In general, labor mobility rates both in the CEE's and in the NIS have been lower than in OECD countries, and especially in the US (see [13] and [107]). On the other hand, there are certain differences between the two sub-regions. While CEE labor markets have been rather flexible, NIS economies have exhibited significant labor hoarding and low job mobility in the beginning of transition. Recently, however, the unemployment rates in the NIS have risen to the levels experienced in the CEE's (see [44] for labor market indicators). The view that NIS labor markets are much more rigid than those of CEE is no longer true: gross worker flows in the NIS are as high as in CEE or even higher [77] and [56].

It is important to notice, however, that these relatively high levels of labor mobility in the CEE and NIS refer to intra-regional hiring and separations. Interregional mobility is rather low. In figure 4.3 we present indices of interregional job mobility in selected CEE's and in Russia. ${ }^{56}$ Churning is taking place, but it is taking place at the local level for the most part. This is rather important, since industry is highly specialized geographically in the NIS. This means that intersectoral reallocation of labor is dependent on inter-regional labor mobility to a greater degree than would be the case in CEE's. As both [77] and [56] insist, there is a lot of job churning in Russian labor market, but workers change bad jobs for bad jobs rather then bad old jobs for good new jobs. ${ }^{57}$ As shown in [106], people who change jobs in Russia do not get a significantly higher salary (except for academics and managers). Certainly, the high interregional differentials [77]

borrow small amounts in the informal credit markets.

${ }^{56}$ The figures in figure 4.3 are gross job flows across regions. They are the sum of the rates of jobs created and jobs destroyed.

57 [56] provides striking evidence from a study of firm-level data from four Russian regions: while gross turnover (hirings plus separations per year) was from 29 to 44 per cent of current employment, new job creation constituted only 1 per cent of current employment. 


\begin{tabular}{lcccccc}
\hline Year & Bulgaria & Poland & Romania & Slovenia & Estonia & Russia \\
\hline & & & & & & \\
1993 & - & - & - & - & - & 0.01 \\
1994 & - & 0.14 & - & 0.09 & 0.21 & 0.00 \\
1995 & 0.08 & 0.20 & 0.30 & 0.10 & 0.35 & 0.00 \\
1996 & 0.20 & 0.12 & 0.03 & 0.30 & 0.03 & 0.05 \\
1997 & 0.01 & 0.26 & 0.01 & 0.00 & 0.26 & 0.00 \\
\hline
\end{tabular}

Figure 4.3: Interregional job mobility in selected transition countries. Source: Faggio and Konings [40], Konings' calculations using Russian enterprise registry RERLD.

suggest that the workers should be willing to leave the depressed regions for more productive jobs in other regions.

Why is interregional mobility in the NIS so low compared with CEE countries? Again, geography plays an important role. Getting a job in another town may be rather easy for smaller countries of the CEE region, but much harder for huge countries of the NIS. Indeed, distances between neighboring regions in Siberia are much greater than distances between CEE countries. Interregional mobility in Russia requires moving rather than commuting. ${ }^{58}$ The costs of moving in transition economies can be rather high. If households are liquidity constrained the pecuniary costs of moving may be prohibitive. Moreover, housing markets are not well developed; this further complicates moving.

The cost of moving is further increased by low unemployment benefits that are the only source of income that workers have to rely upon while searching for a new job. Figure 4.4 shows that CEE economies have consistently had much higher unemployment benefits than in Russia, for example. ${ }^{59}$ Notice that the data presented here is the ratio of average benefit to average wage. As average wages are lower in Russia this means that the cash benefit is substantially lower. Presumably

\footnotetext{
${ }^{58}$ In CEE the maximum distance at which commuting still pays off is estimated at about $30 \mathrm{~km}$ [14]. This is less than diameter of Moscow city and much less than distance between neighbouring settlements in non-European Russia or Central Asia.

${ }^{59}$ See [44] and [22] for more details on labor market arrangements and for discussion of the choice of the level of unemployment benefits in transition countries.
} 


\begin{tabular}{|c|c|c|c|c|c|c|c|}
\hline & $\begin{array}{c}\text { Czech } \\
\text { Republic }\end{array}$ & Hungary & Poland & Slovakia & Bulgaria & Romania & Russia \\
\hline 1991 & 46.3 & 41.0 & 36.0 & 43.8 & 60.6 & 62.6 & 23.6 \\
\hline 1992 & 24.8 & 39.3 & 36.0 & 31.6 & 38.1 & 59.0 & 11.9 \\
\hline 1993 & 28.3 & 36.6 & 36.0 & 29.2 & 35.5 & 37.2 & 8.4 \\
\hline 1994 & 26.6 & 33.0 & 36.0 & 25.3 & 34.3 & 32.5 & 8.0 \\
\hline 1995 & 25.1 & 33.5 & 36.0 & 27.5 & 34.9 & 28.5 & 8.8 \\
\hline
\end{tabular}

Figure 4.4: Average unemployment benefit as a percentage share of the average wage in selected transition countries. Source: Commander and Tolstopiatenko (1996).

it is the cash benefit that is necessary for covering the cost of movement. Even ignoring this denominator-bias, however, the differences in replacement levels is quite remarkable.

The important implication of high moving costs for workers in NIS countries is that it allows employers to attach workers to the enterprises through payment of wages in a non-monetary form [47]. ${ }^{60}$ Since moving costs are high, firms can exploit workers' liquidity constraints and ensure that the option of moving to a prosperous region is rarely exercised. Certainly, attachment imposes costs on workers and does not occur in a competitive labor market. Unfortunately, the depressed communities that the workers want to leave are precisely the ones with monopsonistic labor markets.

There are three major means of attachment: "social" (fringe) benefits, wage arrears and payments of wages in kind. The tradition of paying wage via fringe benefits goes back to the paternalistic structure of the Soviet enterprise that provided its employees with healthcare, housing, kindergartens etc. In many towns social services are still provided by large firms rather than by municipalities. Although federal government has obliged firms to divest the social assets to municipalities, this is happening rather slowly (Figure 4.6).

Provision of social benefits by the older firms reduces incentives for moving

\footnotetext{
${ }^{60}$ See Figure 4.5 for evidence on the fact that that wages in kind are much more common in Russia than in other transition countries. See also [25] for a discussion of the effects of enterprise-provided social benefits on job mobility and restructuring.
} 


\begin{tabular}{lcc} 
Country & $\begin{array}{c}\text { Share of in-kind wages } \\
\text { in total wages }\end{array}$ & $\begin{array}{c}\text { Share of households } \\
\text { that receive wages in }\end{array}$ \\
\hline Estonia & $0.30 \%$ & $2 \%$ \\
Poland & $0.30 \%$ & $4 \%$ \\
Russia & $3 \%$ & $20 \%$ \\
\hline
\end{tabular}

source: authors calculations using the household surveys at www.worldbank.org/research/transition/house.htm

Figure 4.5: Payments of wages in kind

from the old sector to de novo firms even though the latter may provide a higher salary. ${ }^{61}$ Workers prefer to keep two jobs: one with a safe low-wage combined with social services in the old firm and the other a riskier high-pay but without access to good social services. Certainly, multiple job holding makes geographical mobility even more problematic. Instead of finding a job in the new region, the worker has to find two jobs simultaneously. ${ }^{62}$

Another way to attach workers to enterprises is via wage arrears [34]. Empirical evidence demonstrates that wage arrears exist both in distressed and healthy firms. Therefore wage arrears may also be a strategic instrument that firms use to exploit workers' liquidity constraints. ${ }^{63}$ The empirical analysis in [34] discovers a coordination effect: a firm is more likely to have wage arrears if all other firms in the region have wage arrears. The attachment theory therefore explains why wage arrears are so widespread in Russia and much less prevalent in CEE economies (see the Table 4.5). The argument is straightforward: arrears are a symptom

\footnotetext{
${ }^{61}$ Differential tax incidence may also deter workers from switching to new jobs. If old firms provide social benefits that are not taxed, they may prefer to remain at their current jobs rather than switch to de novo firms where they would have lower after-tax incomes. Of course, this effect is mitigated by poor tax collection in transition economies.

${ }^{62}$ Another motive for the multiple job holding was discussed in Subsection 4.1.2. As shown in [61], multiple job holding in Russia reduces the need for precautionary savings acting as a self-insurance device against earnings volatility.

${ }^{63}$ Thus, one could think of arrears as a method for reducing real wages to levels consistent with market alternatives. Of course, one would have to explain why workers are more willing to tolerate arrears than overt real wage cuts. Alternatively, arrears may be understood as a convenient way for the enterprise to borrow from workers. On the other hand, since the workers are more liquidity constrained than the firm, it is socially costly.
} 


\begin{tabular}{llll} 
Fringe Benefit & 1990 & 1994 & 1998 \\
\hline Catering & 55 & 50 & 41 \\
Medical services & 64 & 63 & 56 \\
Vacation facilities & 62 & 56 & 44 \\
Professional training & 78 & 71 & 59 \\
New housing & 45 & 34 & 18 \\
Kindergarten & 66 & 54 & 32 \\
\hline
\end{tabular}

source: Biletsky, et al., (1999)

Figure 4.6: Percentage of Russian enterprises providing fringe benefits.

of a labor market that display significant frictions. When workers cannot move, employers can expoit their monopsony power. There is no point in trying to attach workers in the CEE: the costs of interregional mobility are rather low so even unskilled workers can save enough to move. Even in one of the poorest transition countries, Albania, hundreds of thousands of workers manage to move to neighboring countries, let alone regions. ${ }^{64}$

\subsection{Human Capital Accumulation}

A key characteristic of transition economies is that they start with relatively high levels of human capital. The literacy rates are as high, and sometime even higher, than in OECD countries. In the Baltics, for example, the share of individuals with upper-secondary education or greater ranges from 80 to $90 \%$ of the labor force, compared with about two-thirds on average for OECD countries [93, 159]. As with physical capital, however, the key issue with regard to economic growth is the quality of this human capital. In particular, it is important to ask how suited this human capital is to the needs of a market economy.

The second issue regards the production of human capital. An important question for long-run growth is whether transition itself will damage the systems

\footnotetext{
${ }^{64}$ It is interesting to note that within Russia, the attachment through in-kind wages and wage arrears occurs only in distant regions. Wage arrears and in-kind payments of wages are virtually non-existent in large metropolitan areas.
} 
for re-producing human capital, or whether reformed educational systems will emerge that produce human capital suited to the needs of these economies.

The Soviet educational system, for example, put more emphasis on science and engineering rather than on marketing and entrepreneurship. This problem is present in all transition economies. The level of technical education was very high, especially in math and physics but humanities and business were lagging behind. ${ }^{65}$ The pre-reform experience and skills of the managers may be irrelevant. ${ }^{66}$ In Romania, for example, small businesses where managers had no prior experience in the field performed better than those where managers had such experience [99] (In Russia, de novo firms reward education but not experience [92]).

Notice that even if the existing stock of human capital is inappropriate for transition, the move to market-determined wages increases the return to human capital accumulation. The stories about professors earning less than bus drivers are not revealing: wages were highly compressed under planning, and market forces leads to increased variation. Studies of East European economies suggests that the returns to human capital have increased during transition [108]. ${ }^{67}$ The same appears to be true in Central Asia [98]. Indeed, one might argue that as the transition proceeds the returns to human capital should increase, as the share of the outstanding stock of human capital comprised by transition-era accumulation increases. The acceleration in the growth rate of the return to human capital is found in the Czech Republic and in Slovakia. Indeed, according to [45] by 1997 the returns to education had reached levels comparable to those in market economies. The returns to education in Russia are still very low at $4-5 \%$ per a year of schooling (with over 10\% in East Asia and Latin America, 8-9\% in OECD countries and about 7\% in Czech Republic) [5]. The NIS economies may be going along the U-shaped pattern in the returns to human capital accumulation that CEE countries have gone through with decline and stabilization already seen but a steady increase not yet documented.

Consider the increase in inequality in earnings in transition economies. In table 4.7 it is apparent that income inequality has increased dramatically in transition

\footnotetext{
${ }^{65}$ Whether this is a significant constraint remains to be seen. Ironically, probably the greatest impact is on public policy, where the lack of trained analysts - especially economists - is most pressing.

${ }^{66}$ It has been observed in most transition economies that entrepreneurs often come from positions with research institutes and math and physics training. The example of Boris Berezovsky is probably not atypical.

${ }^{67}$ In Poland, for example, inequality in labor earnings has increased much more than inequality in income or consumption[78]. Social transfers account for the difference.
} 


\begin{tabular}{|c|c|c|}
\hline Country & $\begin{array}{c}\text { Gini Coefficient } \\
\text { Gross Income } \\
\text { per-capita } \\
1987-88 \\
\end{array}$ & $\begin{array}{c}\text { Gini Coefficient } \\
\text { Disposable } \\
\text { Income per-capita } \\
1993-95 \\
\end{array}$ \\
\hline Balkans and Poland & 24 & 30 \\
\hline Bulgaria & 23 & 34 \\
\hline Poland & 26 & 28 \\
\hline Romania & 23 & 29 \\
\hline Central Europe & 21 & 24 \\
\hline Czech Republic & 19 & 27 \\
\hline Hungary & 21 & 23 \\
\hline Slovakia & 20 & 19 \\
\hline Slovenia & 22 & 25 \\
\hline Baltics & 23 & 34 \\
\hline Estonia & 23 & 35 \\
\hline Latvia & 23 & 31 \\
\hline Lithuania & 23 & 37 \\
\hline Slavic Republics and Moldova & 24 & 40 \\
\hline Belarus & 23 & 28 \\
\hline Moldova & 24 & 36 \\
\hline Russia & 24 & 48 \\
\hline Ukraine & 23 & 47 \\
\hline Central Asia & 26 & 39 \\
\hline Kazakhstan & 26 & 33 \\
\hline Kyrgyz Republic & 26 & 55 \\
\hline Turkmenistan & 26 & 36 \\
\hline Uzbekistan & 28 & 33 \\
\hline All transition & 24 & 33 \\
\hline
\end{tabular}

Figure 4.7: Changes in Inequality during the Transition. Source [91, 41]. 
economies over time. Moreover, the variation across countries has increased as well. This is no doubt due to the increased demands for certain skills combined with the obsolescence of others. So increased variation in returns is to be expected. In Central Europe, however, the increases in inequality are small, and still on the order of low income-inequality countries such as the Nordic countries and Belgium. ${ }^{68}$ In the former Soviet republics, on the other hand, the increase in inequality has been rather dramatic; in Russia and Ukraine the Gini coefficient on disposable income is significantly higher than in the United States. This may be due to differences in the size of social transfers which tend to be much larger in CEE countries than in the NIS. ${ }^{69}$

The low rates of return to some types of human capital may indicate either irrelevance of the accumulated skills or abundance of the existing human capital stock. Both are the case to a certain extent. In the long term, however, production of human capital may become a real problem. The fiscal system under stress may not allow to maintain the educational system that produced high levels of human capital under socialism.

\subsection{Health in Transition}

An important element of human capital is an individual's health status. Changes in health status can have long-lasting effects on productivity and earning power, and it can affect decisions with respect to accumulating other skills. Improvements in health status can lead to increases in the supply of effective labor. Improved health can also lead to improvements in the quality of labor. A healthier population may invest more in acquiring skills. ${ }^{70}$ Thus deteriorating conditions in the health system can have long-lasting effects on the growth potential of the

\footnotetext{
${ }^{68}$ Countries with Ginis between 20 and 22 are generally considered very low income-inequality countries. High income-inequality countries, such as Switzerland and the United States have Ginis between 33 and 35. See [91, 40].

${ }^{69}$ Thus average cash transfers as a share of GDP (through 1997) were as high as $17.7 \%$ in Poland, $14.8 \%$ in Slovenia, $16.5 \%$ in Hungary, and $12.1 \%$ in the Czech Republic, compared with $8.9 \%$ in Belarus, $6.9 \%$ in Kazakhstan, $7.5 \%$ in Russia, and $9.4 \%$ in Ukraine. Once again, Bulgaria (11.8\%) and Romania (8.9\%) lay somewhere in the middle. See [78, table 8].

${ }^{70}$ There is both a supply and demand effect at work. The need to cope with a health crisis may absorb resources that could otherwise be used for education. More important, perhaps, the healthier the population the greater the return to acquiring skills, as this asset would be expected to produce income for a longer time period.
} 
economy. ${ }^{71}$

An important behavioral shift occurs in transition with regard to health. Under socialism the health system was socialized, as were the costs associated with ill health. In market economies, however, an increasing share of the costs associated with ill health fall on the household. Job loss due to ill health, for example, will have a greater impact on household consumption in the new environment. Households obtain more discretion about their investment in health at the same time that they bear increased consequences over the outcome. It is not clear, however, how fast is the response to these changed conditions. It could be that adverse health outcomes are the result of failure on the part of households to respond rapidly and effectively enough.

Transition economies, in general, inherited health systems that were rather advanced for their per-capita incomes, but ill-suited to the health concerns that are associated with economic development (heart disease, etc). One important element is thus mismatch. In poor countries the basic health problem is the incidence of infectious diseases, malnutrition and inadequate health services. In transition economies these problems are somewhat less severe. Rather, the problem is that behaviors associated with higher incomes - diet, smoking, etc. - cause infirmities that the health care system is not capable of coping with. This is partly due to a lack of reform of the system as these economies developed. It is also due to the stresses encountered during transition, primarily because of the impact of fiscal shortfalls on health systems that were financed entirely from public revenues. So increased health problems in transition are due to the disequilibrium or mismatch in the health system.

One of the key stresses that health systems in transition must cope with is financial. Under socialism health care was provided from central government revenues and from state-owned enterprises. The latter tended to provide clinics and hospital services for employees. Enterprises were a conduit for the supply of health services to the population. Because the enterprises were state-owned this amounted to another channel for state-supported health services. With transition, however, the financial base for the health system is transformed in consequential ways. Enterprise privatization necessitates an alteration in this system, with payroll taxes replacing enterprise-provision of health care services. In addition, private health care becomes feasible only during transition. ${ }^{72}$

\footnotetext{
${ }^{71}$ This effect has been emphasized by [46] who estimates that improved nutrition accounts for $50 \%$ of the growth in per-capita income in Britain from 1790 to 1950.

${ }^{72}$ The share of the private sector in total health expenditures remains rather small in most
} 
Because of the observed increases in Russian mortality in the early transition period the question of a link between health status and the pace of liberalization has been studied. Early studies (e.g., [102]) detected a negative relationship between the pace of reform and the increase in mortality. Further research indicates that the relationship is more complex. Indeed, it appears that the the negative correlation between speed of reform and mortality holds only in the CEE's. In the FSU, in fact, the most rapid reformers (especially the Baltic republics) have experienced larger increases in mortality [11, 2025].

\section{Enterprise restructuring}

The key challenge of transition is to increase the efficiency of resource use so that economic performance can be enhanced. Because economies in transition are already industrialized, the role of the enterprise takes the center stage. This is a simple result of the share of GDP produced in the enterprise sector. Improvements in economic performance depend on enterprise restructuring. Looking across the region it is apparent that there is a wide range of experiences in this regard. Our purpose in this section is to explain the characteristic differences in restructuring experience.

There are three primary mechanisms through which enterprise restructuring takes place. First, an improved allocation of resources across uses depends on the creation of effective markets for capital, labor, and resources. ${ }^{73}$ Second, existing enterprises can use resources more efficiently. This requires enterprise restructuring. Third, new firm formation is critical to efficiency and growth. We consider new firm creation below in section 6 . In this section, our focus is on restructuring.

It is analytically useful to distinguish between various aspects of restructuring [See [69] and [26]]. The most basic aspect of restructuring is survival-oriented. As budget constraints are hardened enterprises must reduce costs to survive. This aspect of restructuring is reactive and typically involves internal adjustments of the enterprise. The second aspect is growth-oriented restructuring. ${ }^{74}$ This involves

transition economies. Hungary appears to be an exception, where the share of the private health expenditures to GDP (2.06\% in 1994) is roughly similar to that of high-income OECD countries. In the Czech Republic (0.46\%), Poland $(0.29 \%)$ and Russia $(0.65 \%)$ this share is much smaller $[115$, table 8].

${ }^{73}$ See [44] for a detailed study of product and factor markets in transition economies.

${ }^{74}$ Alternatively, one may distinguish three types of restructuring: survival-oriented, which involves reductions in activities to satisfy budget constraints; internal, which involves reor- 
attempts to enhance revenues by improving existing products and introducing new ones. It is this second aspect which is critical to the long-run performance of the economy. It is also more complex and problematic to achieve.

There are two policy instruments that have been used in transition economies to improve enterprise efficiency. First, and most basic, is the elimination of softbudget constraints. Eliminating subsidies is critical to induce enterprises to act more efficiently. It is only a first step, however. The second, and more important, has been privatization of existing state-owned enterprises. In virtually all transition countries some form of privatization has occurred. Although the connection between privatization and improved efficiency appears straightforward theoretically, the evidence in fact is more complex. One of the most important puzzles of economic transition is the weak empirical relation between privatization and economic restructuring.

We consider both of these issues in this section. Our concern is to understand what factors inhibit enterprise restructuring, and to explain the differences in this relationship across the region.

\subsection{Soft budget constraints}

In most transition economies formal subsidies have been eliminated [101]. Some evidence is available in figure 5.1. Although explicit subsidies have declined as a share of GDP throughout the region [[101], [36]], they have often been replaced by informal subsidies. The latter take various forms. These are tax arrears that are written off or restructured, interfirm arrears that are never paid and wage arrears. The percentage of bad loans has also been notorious. The most important form of subsidies in the NIS is the continued delivery of low-cost energy. Enterprises do not pay the full cost of their energy use, and energy suppliers fall into tax arrears with the government.

The composition and the magnitude of soft budget constraints varies across region. They are more widespread in NIS, less so in Romania, and relatively small in CEE.

Why are soft budget constraints so common in NIS and so rare in CEE? The explanations are different for the subsidies provided by private and public creditor. $^{75}$ The most straightforward explanation is competition. When there

ganization of practices within the enterprise, and; external, which involves changing the way enterprises interact with other enterprises and consumers. See [69] for an application.

${ }^{75}$ Though in many cases - e.g., Gazprom in Russia - it is very hard to draw the line between 


\begin{tabular}{lrrrr} 
& 1994 & 1995 & 1996 & 1997 \\
\hline Eastern Europe and the Baltics & & & & \\
Bulgaria & 1.3 & 1.2 & 0.8 & 0.8 \\
Croatia & 2 & 1.8 & 1.9 & 1.9 \\
Czech Republic & 3.1 & 2.7 & 2.2 & 2.4 \\
Estonia & 0.9 & 0.5 & 0.4 & 0.3 \\
Hungary & 4.5 & 3.8 & 3.9 & 3.3 \\
Latvia & 0.2 & 0.4 & 0.3 & 0.4 \\
Lithuania & 1.7 & 1.1 & 1.3 & 0.9 \\
Poland & 3.3 & 2.9 & 2.5 & 2.4 \\
Romania & 3.8 & 4.1 & 4.3 & 2.6 \\
Slovak Republic & 3.2 & 2.8 & 2.4 & 2.2 \\
Slovenia & 1.6 & 1.6 & 1.2 & 1.3 \\
& & & & \\
CIS & & & & \\
Armenia & 12.8 & 0.9 & 0.1 & 0.4 \\
Azerbaijan & 5.4 & 2.2 & 2.1 & 0.7 \\
Belarus & 6.3 & 3.4 & 2.9 & 1.3 \\
Georgia & 13.8 & 1.1 & 1 & 1.5 \\
Russia & $\mathrm{n} . \mathrm{a}$. & $\mathrm{n} . \mathrm{a}$. & 6.2 & 6.4 \\
Uzbeksitan & 1.9 & 3.4 & 4 & 3.2 \\
\hline source: Commander 199.4 & & &
\end{tabular}

source: Commander 1999.

Figure 5.1: Budgetary Subsidies to Enterprises (\% of GDP) 
is only one buyer a situation of mutual dependence develops. The seller cannot cut off the buyer if that will eliminate the only enterprise for the market. The seller responds by delivering goods even when the buyer is in arrears. Essentially, the seller is lending to the buyer to prevent the alternative of closure. The same applies to workers. They lend their wages to their employer since there is no other employer in the town. The explicit subsidies and tax arrears may be explained by politicians' self-interest. We address the political explanation in the Subsection 5.6 .

\subsection{Privatization and Restructuring}

Privatization is seen as the key policy instrument to induce former state-owned enterprises to restructure. The argument is that changing ownership will provide managers with high-powered and correctly aligned incentives, and hence lead to improvements in economic performance.

\subsubsection{Analytical Issues}

Although privatization has been widespread in transition economies the degree to which it has induced restructuring varies across economies [see 5.2.3]. This presents a puzzle if restructuring is considered as the only means of enterprise survival. In [53] it is argued that enterprises in transition economies actually have an alternative strategy for survival; investing in relations. Investments in relational capital are useful because they afford the enterprise the ability to survive without satisfying budget constraints. ${ }^{76}$ According to this two-dimensional view of restructuring, enterprises vary according to their initial degree of inefficiency, $d$ (distance to the market), and their level of relational capital, $r$. Enterprises can survive either by reducing $d$ or increasing $r$. The actual choice an enterprise will make depends on its initial values of $d$ and $r$, and on the relative returns to these activities.

Once we accept this two-dimensional picture it is apparent that the effectiveness of privatization will depend on initial conditions as well as policies that are chosen. For example, resource abundance may increase the likelihood of subsidies; hence the return to investing in relational capital may be higher in such

private and public.

${ }^{76}$ For example, relational capital allows enterprises to engage in barter, to pay taxes in kind, and to engage in arrears. 
economies. $^{77}$

Notice that relational capital requires non-transparency - agents are treated idiosyncratically. This suggests that economies with legacies of non-transparency may see greater investment in $r$. The more transparent are a country's institutions the more costly is investing in $r$; hence, in these economies enterprises will see a greater relative return to restructuring. ${ }^{78}$

\subsubsection{Methodological Issues}

Disentangling the empirical relationship between privatization (ownership type) and enterprise restructuring is complex. We want to discern whether ownership type leads to greater restructuring. There are three main problems. First, although easy to understand, restructuring is not easy to define. It refers to a multitude of changes in the way the enterprise performs. Hence, obtaining indicators of restructuring can be complex, and often differs across studies. Some use quantitative indicators, such as the change in output, revenue, or employment. Others use qualitative indicators from surveys.

The second problem is selection bias. Studies of enterprise restructuring estimate an equation of the form:

$$
y_{i}=\alpha+\beta x_{i}+\gamma P_{i}+\varepsilon_{i}
$$

where $y_{i}$ is a performance indicator, $x_{i}$ is a vector of enterprise characteristics that would include initial performance, and $P_{i}$ is the ownership type. Studying the effects of privatization on restructuring involves estimating $\gamma$. The problem is that ownership types are most likely not randomly determined. ${ }^{79}$ If ownership type is systematically related to some determinant that also affects $y_{i}$, but is not included in $x_{i}$, then estimates of $\gamma$ will be biased. For example, are privatized enterprises more productive because they are privatized, or were enterprises with

\footnotetext{
${ }^{77}$ Notice that an energy-abundant country can not only afford subsidies, but large exports leads to currency appreciation that may make manufacturing exports less competitive. Hence, it may also increase $d$ for many enterprises.

${ }^{78}$ Note that the promise of EU accession may play a similar role: as soon as the country joins EU, the relational capital loses all its value. Anticipating lower returns to the relational capital, managers prefer restructuring.

${ }^{79}$ In [89] this hypothesis is tested directly on enterprises in the Czech Republic. They find that, indeed, enterprises were not chosen randomly for different privatization methods, and that controlling for selection bias alters the evaluation of its effects.
} 
better initial conditions more likely to be privatized. ${ }^{80}$ Many empirical studies of restructuring pay attention to selection bias, but it is not always easy to find appropriate instruments.

The third problem is that measuring ownership is hardly straightforward. It is easy to distinguish between state-owned enterprises and those that are not. But within the latter category one finds many different types depending on which group dominates ownership: employees, managers, financial companies, domestic outsiders, foreign outsiders. These various forms of private ownership are quite heterogeneous, and it would be surprising if the effects on restructuring would be invariant to these forms. But the decision to choose which type is not random, which introduces the noted selection bias. Moreover, within individual countries there is often not sufficient numbers in all types to discern the effects of the different categories.

\subsubsection{Empirical Studies}

Various studies have attempted to study the connection between privatization and restructuring, and many have tried to control for selection in various ways [e.g., [36], [97], and [49]]. ${ }^{81}$ In [97] the initial level of productivity is used to control for selection bias. ${ }^{82}$ But this works only to the extent that productivity is measured correctly. In [49] selection is controlled for by dropping enterprises purchased by insiders - which is effective at controlling selection due to insider bias, but does not deal with other sources ${ }^{83}$ - and by estimating a fixed effects model. Other papers use instrumental variables techniques to control for selection.

Empirical studies tend to focus on privatization in one country or a group of neighboring countries. There are few studies that include data across the NIS and CEE. Nonetheless, it is possible to obtain some results by comparing across studies. There are several robust findings. First, the type of privatization matters: inside ownership appears to differ little from state ownership, while outside

\footnotetext{
80 [33] surveys a vast array of empirical studies on restructuring. They observe that the selection bias is important, but that the direction of the bias seems to differ across studies.

${ }^{81}$ For a survey of such papers and a rating of their efforts to deal with selection bias, see [33].

${ }^{82}$ Because of the difficulty in measuring capital services, [97] use energy use as a proxy. But this means that countries where enterprises have not had incentives to reduce energy use in transition will have higher "measured" capital services, and hence lower productivity growth. Hence, differences across countries ([97] uses pooled data for various economies) in energy prices can contaminate productivity measurements.

${ }^{83}$ For example government decisions about which enterprises to privatize based on political decisions.
} 
ownership tends to induce more significant effects on performance. Second, and related to the first, it is typically observed that the impact of privatization on restructuring is greater the more concentrated is ownership. Third, competition matters; the greater the degree of product market competition the greater the level of enterprise performance. Fourth, it appears that there are differences according the measure of performance used. In [49] the effects of ownership types are found to be much greater with regard to revenue and productivity than with cost or employment. One interpretation of this finding is that hardening the budget constraint causes common effects across ownership types with regard to cost and employment. This is a reactive response, and will hardly differ based on who controls the firm. But increasing revenues and productivity requires entrepreneurial effort which will likely differ according to ownership type.

Perhaps most important for our purposes, the evidence strongly suggests that the effect of privatization on restructuring is much greater in CEE's than in the NIS.

The results from empirical studies of restructuring suggest that privatization is effective only when private owners are able to control management. Therefore the effect of privatization depends on the strength of corporate governance.

\subsection{Corporate governance and enterprise finance}

The conflict of interests between managers and owners is a problem in all economies, but it is paramount in transition economies. The corporate governance environment has been very poor in transition economies [44]. This is partly due to the legacy: there were no joint stock companies before the reform started. All legal and market institutions had to be designed from scratch. The transition countries had to re-introduce such things as rule-of-law, an independent court system, stock markets, insurance etc. Since institutional memory in CEE's is much better (there are still generations that lived under capitalism) than in the NIS, the success in re-building these institutions was very different. This is not a problem of legislation: most NIS countries have adopted legislation that is the same or even better as in CEE or OECD. However the enforcement of the laws in the NIS has been rather poor.

Managers use the imperfections of legal system and the poor enivonment for corporate governance to divert profits. ${ }^{84}$ The widespread use of transfer pricing

\footnotetext{
${ }^{84}$ The absence of a managerial labor market at the onset of transition is an important factor in the incentive to divert income. Without managerial labor markets, incumbent managers
} 
and barter payments in Russia helps managers divert corporate profits away from the company (often offshore) leaving outside investors with nothing. ${ }^{85}$ Under the present legal system it is very hard for minority shareholders to influence management. Only when outside investors take over a qualified majority can they replace the manager (and therefore become insiders themselves). And often, local governors protect incumbents against the activities of outside shareholders, even to the point of using police to prevent them from entering shareholder meetings. ${ }^{86}$

Good corporate governance also requires clearly defined bankruptcy procedures. Russia's recent bankruptcy experience shows however that a good bankruptcy law does not make things any better if there are no independent courts to enforce it [86]. In 1998, Russia has introduced a long overdue bankruptcy law. The law was similar to the Mexican one and was praised by many as sufficiently tough on managers giving creditors a good chance to get their money back. After the inception of the law, number of bankruptcies has indeed skyrocketed. The creditors (including federal government) however have not received much. The judges effectively controlled by regional governments often ruled in favor of the latter.

As argued by Bergloef and von Thadden [6] corporate governance in transition economies is developing in the direction of German-Japanese model rather than the Anglo-Saxon one. Small investors are relatively unprotected. Only large shareholders can expect positive returns. This makes the stock market very thin and makes reallocation of capital quite costly. Therefore firms that contemplate restructuring cannot easily find external sources of finance. On the other hand, until they restructure they do not have enough profits to re-invest. The liquidity constraints caused by underdevelopment of financial markets and poor corporate governance create the vicious circle of survival without restructuring. Managers make suboptimal decisions; they invest in relational capital rather than in restructuring. [62] provide evidence on the use of barter by managers to survive without restructuring. Also, managers can use barter (relational capital) as a means of entrenchment (as projects with asymmetric information in [37] ). Lack of restructuring and managers' entrenchment reduce incentives of outside investors to bring

have few ways of appropriating returns that may be due to their efforts, unless they manage to own a significant block of shares. With privatization schemes that gave incumbent managers relatively small packets (compared to workers) the incentive to divert assets was larger than otherwise might have been. A managerial labor market allows incumbents to earn returns on any improvements they are responsible for, even if they do not own a large bloc of shares. For an early analysis of this issue, see [68].

${ }^{85}$ These instruments are also used to evade taxes.

${ }^{86} \mathrm{See},[8]$ for a littany of corporate governance tragedies in Russia. 
cash and even replace managers.

\subsection{Role of competition and openness}

Competition is an important contributor to improved economic performance. Competition improves static efficiency by pressuring managers to maximize profits. The effect on dynamic efficiency is less clear, however. Competition forces enterprises to keep up with improvements in technology, but monopoly profits are the primary goal of innovators. In transition economies the legacy is of monopolistic enterprises that lacked all dynamism. Hence, it is restructuring that is crucial to improved performance, and the role of competition is almost surely paramount. $^{87}$

Competition can come from two sources: the internal market, and increased openness to foreign competition. Empirical evidence suggests that competition improves efficiency, though the effect appears to be non-linear. More competition is good, but too much inhibits restructuring. ${ }^{88}$

The extent to which enterprises face competition is correlated with ownership types. Privatized enterprises (and new entrants) are much more likely to face competition that state-owned enterprises $[36,136]$. There are perhaps two reasons for this. First, state-owned enterprises may perceive less competition because they receive state protection. New entry may be more difficult in enterprises dominated by large state-owned enterprises. Second, and more important, the nature of privatization programs themselves may be responsible. Those enterprises left in state hands tended to be in less competitive sectors of the economy. ${ }^{89}$

Even if firms maximized profits, the lack of competition and openness could prevent the economy from achieving efficient outcomes. The Soviet industrialization model created highly specialized firms that often relied on a single supplier. ${ }^{90}$ Within a country many enterprises faced only one potential buyer. Given contractual difficulties and lack of information these situations of bilateral monopoly

\footnotetext{
${ }^{87}$ Though probably still secondary compared with elimination of soft-budget constraints. Notice, that as long as soft-budget constraints exist competition is irrelevant.

${ }^{88}$ See $[36,132]$. This effect was first analyzed by [69]. This appears to be due to the fact that restructuring relies so heavily on internal financing. Hence, as competition increases internal financing dries up.

${ }^{89} \mathrm{This}$ is one of the factors which makes it so difficult to estimate the efficiency-enhancing effect of privatization: selection bias created by privatization.

${ }^{90}$ See [69] and [12] for discussion of the role of asset specificity and supplier dependence, and [82] for firm-level evidence.
} 
were reinforced. Under such circumstances openness of the economy becomes crucial. Firms that could compete in the export markets experienced much higher returns to restructuring. The difference between performance of exporting and non-exporting industries in the transition economies is striking. In Russia, industrial output declined by about a half in 1991-98. The decline in the oil industry was only 10 per cent. The same dichotomy occurred in CEE. In Hungary, the sectors that were exporting to the West experienced little decline or even some growth while those oriented on sales to the domestic market or the CMEA declined significantly. Since on average, CEE economies were less specialized and geographically closer to the Western Europe, they found it easier to compete in the export market.

Lack of access to foreign markets may be considered a temporary barrier. If a firm were able to borrow and invest in building competitive production lines they would be able to restructure. The corporate governance problems we have discussed have the effect, however, of leaving NIS firms liquidity constrained. The only way to finance restructuring is to reinvest profits. Profits, however, are low precisely because of lack of access to export markets.

Empirical studies have shown that competition has a positive impact on performance both in CEE and NIS [33]. A large survey (3000 firms in 20 transition economies) [21] supports the positive effect of competition in general and foreign competition in particular. ${ }^{91}$ The effect is very strong within countries: the evidence the from comprehensive dataset of Russian firms shows large and significant effects of competition [18]. This is also observed in Mongolia that lags behind CIS in terms of development of market institutions [4].

\subsection{Contractual imperfections}

Underdevelopment of legal institutions imposes a heavy burden on transition economies. The high level of asset specificity inherited from STE requires enforcement of sophisticated contracts. As mentioned above, in most transition countries, legislation has made it feasible to write all kinds of contracts but the court system generally fails to enforce them. This is especially common in NIS

\footnotetext{
${ }^{91}$ The distinction between domestic and foreign competition is important. It is not only due to the weakness of domestic market that exporting firms outperform domestically oriented. The effect is observed not only in CEE but also in Russia where the domestic market is potentially quite large. [2] shows that those Russian regions that exported more before the transition, have performed significantly better than others.
} 
(see [50] and [74] ). In CEE countries courts do not work perfectly but are indeed used in conflict resolution. In NIS, firms tend not to believe that courts will enforce contracts. ${ }^{92}$

There are a few alternative solutions to contract enforcement through courts. Relational contracting is one potential solution that is used rather widely [74]. Contract enforcement via organized crime is also very common in small businesses [51]. Payments in kind can be used as a hostage in contract relationships to mitigate the hold-up problem [90].

The incomplete contracts literature [63] suggests that vertical integration may also help to overcome contractual imperfections. Indeed, vertical integration is quite common in these environments. Registered vertically integrated groups [19] employ $8 \%$ of industrial employment in Russia; unregistered groups are much larger and have even greater employment. Vertically integrated firms are predominant in such industries as oil extraction and processing, natural gas, steel production, cars etc. [17] show that controlling for other factors vertical integration does help to increase labor productivity.

Though organized crime, barter and vertical integration reduce transaction costs of relation-specific investment, these solutions are not at all innocent. Organized crime has a strong negative effect on small business development. Barter reduces transparency and is therefore very costly for corporate governance and tax collection. Vertical integration forecloses markets. Figure 5.2 shows that the greater the share of vertically integrated firms in a market, the lower is the rate of entry. ${ }^{93}$

\subsection{Enterprise-government interaction}

One of the key barriers to restructuring is political pressure. Since restructuring results in (at least a temporary) increase in unemployment, both federal and local government officials are reluctant to encourage it. ${ }^{94}$ Increased unemployment

\footnotetext{
${ }^{92}$ See [65] for evidence on enterprise attitudes towards contract enforcement and the use of law.

${ }^{93}$ This is consistent with the discussion of the role of Korean groups ('chaebols') that have been instrumental in promoting growth and investment but whose rigidity has become a burden in the Asian crisis.

${ }^{94}$ The simple model in [103] describes the nature of bargaining between politicians and firms. Politicians are interested in maintaining employment levels rather than restructuring. Managers would like to restructure and get rid of the burden of excess employment, but they are compensated by explicit or implicit subsidies from the politicians. Of course, under central planning
} 


\begin{tabular}{|c|c|c|c|}
\hline & $1996-97$ & $1995-96$ & 1995-97 \\
\hline$\overline{M E S}$ & $-0.17 \star \star x \star(0.04)$ & $-0.15 \star x \star(0.05)$ & $-0.30 \star \star \star(0.05)$ \\
\hline CR 1 & $0.031^{\star \star \star}(0.006)$ & $0.098 * \star \star(0.010)$ & $0.096 \star \star \star(0.011)$ \\
\hline G row th & $0.030 \star \star \star(0.002)$ & $0.085 \star \star \star(0.002)$ & $0.074 \star \star \star(0.002)$ \\
\hline Vshare & $-0.018 *(0.01)$ & -0.084 & -0.074 *ᄎ $(0.028)$ \\
\hline Const & $0.021^{\star \star \star}(0.004)$ & $0.023 \star \star \star(0.006)$ & 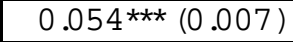 \\
\hline Obs. & 3882 & 3438 & 3336 \\
\hline$\overline{\mathrm{R} 2}$ & 0.05 & 0.36 & 029 \\
\hline
\end{tabular}

Figure 5.2: OLS regressions for entry rates in Russian product markets. Vshare is the share of vertically integrated firms in market, MES is minimum efficiency scale, CR1 is the market share of the largest firm in the market, growth is the growth rate. Source: [19].

may also exacerbate fiscal problems. To a large extent these problems are not specific to transition economies. But the degree of restructuring required in transition economies is much greater than in most other countries, hence the political economy issue becomes paramount.

Another problem with local government is that officials are rarely interested in the geographical mobility of products and resources in general and labor in particular. Local authorities in depressed company towns are reluctant to let skilled workers leave for other more prosperous regions since this would decrease the average income of the town. Therefore there is little surprise that local authorities are quite happy to see social assets (hospitals, kindergartens, housing, recreation facilities) continue to be operated by firms. As we argued above firms may use the social assets as a means of attaching workers which is perfectly aligned with local politicians' interests [48]. On the other hand, local governments in prosperous communities that represent incumbent workers may not be happy to see incoming skilled labor since it would drop the wages and therefore welfare of median voter. Hence, the proliferation of administrative barriers to geographical mobility. The only party that is not represented in the political process are the skilled workers who want to move. Their interests are in theory protected by a federal government that should disburse targeted benefits to encourage mobility. Cash-strapped

the opposite was the case - managers wanted to pad employment to provide a safety factor in fulfilling plans. Nonetheless, there is some evidence that is consistent with this story [33] in transition economies. On the other hand, as we have discussed above [section 5.2.3] it matters a great deal who the managers are; insiders and outsiders act very differently. 
budgets, however, do not allow for these benefits to be set at any reasonable level.

It is important to emphasize that the behavior of regional and local authorities appears to be explained better by the assumption of rational economic agents as opposed to ideology-constrained politicians. As [2] shows, the political orientation of a regional governor has no significant effect on either the choice of policies nor on the performance of the regional economy. This suggests that the policy decisions of local governments are determined, for the most part, by the initial conditions and constraints that they face. One might then argue that the promise of EU accession may be an important factor in restraining the predatory impulses of officials in CEE's; the promise of accession may operate as a commitment device to provide regional governments with the right incentives [44]. In CEE's, politicians know that they will have to cancel the most inefficient policies in a few years, while in NIS, there is no such clear endgame.

\section{New firm creation}

Developing new firms and fostering small business is an important aspect of economic transition in at least in two respects. First, the legacies of the STE leave huge market niches especially in services. By filling these niches, small business can significantly improve welfare. Moreover, new firms are not burdened by the past; they are much more likely to follow market-like practices. It is not surprising, then, that in many CEE countries, small business formation has indeed become a key engine of growth.

Second, small businesses provide an income source for workers that are laid off by restructuring firms. Given the state of public finance in transition economies, the benefits received by the unemployed are rather low, despite high payroll taxes. If more restructuring results in greater unemployment, and if this causes higher taxes to support the unemployed, the economy can end up in a fiscal trap[1]. Selfemployment can thus act as a safety valve that prevents this trap from emerging. The social cost of restructuring is greater when self-employment is less common, and therefore the political pressure to delay restructuring increases.

The rates of small business formation varies a lot across countries. Since

pre-reform distortions were higher in the NIS than in CEE, the potential for small business growth should have been higher in the NIS. This potential has not materialized: the number of small business per capita in Poland is roughly ten 
times as high as in Russia (according to official statistics). ${ }^{95}$ In this section we will try to analyze an entrepreneur's decision to start up and invest in a small business in a transition country and compare environment in which small firms operate in CEE and NIS.

There are several potential barriers for small businesses. First, given the level of financial development in the transition, small businesses may face financial constraints. Second, there could be tough competition from other small businesses. All the profitable niches have already been taken and it is hard to get high profit margins. Third, there may be predatory behavior of government and/or private rackets.

Surprisingly, the empirical evidence indicates that financial constraints are not critical either in CEE or in NIS [36]. In a survey of small manufacturing firms in Poland, Slovakia, Romania, Russia and Ukraine, Johnson et al. [75] show that access to credit does not affect investment. Frye [50] studies shops in Moscow and Warsaw and also corroborates that shopkeepers do not see finance as major problem. The niches for small business are so huge that the businesses that do get through are able to earn enough profit to support business growth.

There is a clear dichotomy between CEE and NIS in terms of competition and government predation. In the CEE, competition has already become an important constraint. Unlike their counterparts in Moscow, shopkeepers in Poland name competition as their major concern [51]. In the NIS, the major problem is predation. Small businesses are taxed and regulated at exorbitant rates. In order to survive they hide some or all of their incomes and become part of the unofficial economy. Once in the unofficial economy, the firm is prevented from seeking contract enforcement and protection from the state. These services are provided by members of organized crime who extract most of the monopoly rents in exchange. ${ }^{96}$ In the CEE (inclusive of Romania and Bulgaria) small firms report that neither government nor private rackets are an important problem. In the NIS firms do not grow enough to fill out all the niches; hence competition is much less intense and monopoly rents correspondingly greater. These rents are an attraction to predators, whether public or private. Hence, there is a relationship between the extent of competition and the degree of predation.

\footnotetext{
${ }^{95}$ Many small firms are just dummies registered for tax avoidance purposes. Given Russia's larger unofficial economy [73], one could assume that the share of tax dummies among small firms is greater in Russia than in Poland. Therefore, the difference is, almost certainly, even more striking.

${ }^{96}$ Corrupt bureaucrats also play a role.
} 


\begin{tabular}{|l|l|l|l|}
\hline Country & Romania (4 cities) & Poland (Warsaw) & Russia (Moscow) \\
\hline $\begin{array}{l}\text { Used courts in last two } \\
\text { years }\end{array}$ & 0.20 & 0.14 & 0.19 \\
\hline $\begin{array}{l}\text { Needed to use courts } \\
\text { but did not }\end{array}$ & 0.15 & 0.10 & 0.45 \\
\hline $\begin{array}{l}\text { Can use courts against } \\
\text { government }\end{array}$ & 0.51 & 0.41 & 0.50 \\
\hline $\begin{array}{l}\text { Can use courts against } \\
\text { business partner }\end{array}$ & 0.67 & 0.45 & 0.65 \\
\hline $\begin{array}{l}\text { Contacted by racket in } \\
\text { the last 6 months }\end{array}$ & 0.00 & 0.08 & 0.39 \\
\hline $\begin{array}{l}\text { Does one need a 'roof' } \\
\text { ('umbrella') to operate? }\end{array}$ & 0.01 & 0.06 & 0.76 \\
\hline
\end{tabular}

Figure 6.1: Government vs. private of contract enforcement for small businesses. Source: [99] and [51]. 'Roof' and 'umbrella' are euphemisms for mafia protection in Russia and Poland, correspondingly.

This clear-cut dichotomy helps to explain why small business performance is so different in the CEE and NIS. In a competitive world, investment that reduces marginal cost is profitable and therefore will be undertaken. In the predation model, however, the fruits of the investment will be expropriated by rent-seekers. Also, investment and growth make the firm more visible, less mobile and therefore subject to more bribe extortion.

This may explain another stylized fact. Controlling for the firms' lifecycle, [80] finds that small businesses in CEE are more efficient than the large firms. This is despite the fact that at the start of transition the opposite was true. ${ }^{97}$ In the NIS, however, there is no significant difference in performance [80].

Notice that the dividing line with respect to the small business environment lies to the east of Bulgaria and Romania. From a small businessman's point of view, Romania and Bulgaria (as well as the Baltic States) are closer to the Visegrad countries than to the NIS. ${ }^{98}$

Apart from government predation, the development of small business is slowed down by a number of economies of scale that are present in the NIS countries.

\footnotetext{
${ }^{97}$ See [68] for a theoretical analysis, and [15] for empirical analysis.

${ }^{98}$ Actually, [99] reports that most small businesses in Romania do not understand the words 'umbrella' and 'roof'.
} 
One is due to the peculiar institution of barter that has flourished in Russia and to a lesser extent in the other NIS economies. For a large firm, the transaction costs of barter may be low relative to other costs, as the more diversified the firm is, the easier it will be to solve the problem of double-coincidence-of-wants. On the other hand, a small single-product entrepreneur cannot afford to hire a barter broker, nor to spend her time searching for appropriate barter exchanges. Therefore thin monetary markets and thick barter ones benefit large firms and hurt smaller ones. In addition, barter is more common in enterprises with historical relations which again presents a bias against new enterprises [70].

Another source of increasing returns is social asset ownership. As we mentioned above, a large share of social assets still belongs to large firms who use them strategically for attaching their workers. The quality of municipal social services is much lower. Therefore the employees of small firms that cannot afford running their own hospitals or kindergartens have to be compensated for being deprived of the higher quality social services.

Political economy is also important. Since the number of small businesses in the NIS is very low, politicians pay greater attention to the interests of large firms. Therefore most subsidies and tax breaks tend to go to large enterprises.

\section{Conclusions}

Although CEE and NIS entered transition with similar problems due to a shared insitutional legacy, their growth performance has been strikingly different. We have discussed possible microeconomic explanations of this difference. The failures of NIS economies can be explained, in part, by the differential legacies from the prior regime. We have emphasized factors which have hampered the development of market institutions because, we have argued, this has reduced labor mobility, the rate of firm formation and the degree of restructuring in existing firms. We have also emphasized the role of openness and competition in explaining differential performance across the region.

These factors, combined with defects in the political and legal system, have given rise to a vicious circle of resistance to reform in the NIS. Workers cannot move. Privatization does not provide existing firms with incentives to restructure. New firms are not established or even if established do not grow as fast as they could. Given this environment, local governments act in a predatory fashion which further worsens the returns to serious reform. The situation in the CEE's is rather different. The rewards for success are more apparent due to greater transparency, 
and they are often greater due to greater access to world markets.

Our purpose in this paper was not only to provide a general account of microeconomics of growth in the region but also to set the framework for future country studies. By introducing two extreme models (a 'typical CEE' economy and a 'typical NIS' economy) we intended to provide future researchers with a set of dimensions along which one can measure how close each economy is to one of these extremes. Because transition is multi-dimensional, however, the position of a country on this spectrum may differ depending on the criterion. Thus, Bulgaria and Romania - where growth performance has been in between the NIS and the Visegrad - seem to be intermediate cases from the microeconomic point of view, too. In Bulgaria and Romania, enterprise restructuring has been rather slow making them similar to NIS. On the other hand, the rates of small business development are rather close to those in Visegrad countries. Perhaps, the most interesting question of transition can be answered by studying which of these two positions on the spectrum dominates long-run economic performance in Bulgaria and Romania. 


\section{References}

[1] Aghion, P., and O. Blanchard, "On the Speed of Transition in Central Europe," in S. Fischer and J. Rotemberg, eds., NBER Macroeconomics Annual 1994, MIT Press.

[2] Ahrend, Rudiger (2000). Speed of Reform, Initial Conditions, Political Orientation, Or What? Explaining Russian Regions' Economic Performance, RECEP Working Paper 2000/2.

[3] Alexashenko, Sergei (2000). 'On Fighting the Capital Flight'. Current Review of Russian Economy, Development Center, Moscow, March 2000. [In Russian]

[4] Anderson, James, Young Lee and Peter Murrell (1999). 'Do Competition and Ownership Affect Enterprise Efficiency in the Absence of Market Institutions and Evidence after Privatization in Mongolia'. Mimeo, University of Maryland.

[5] Benitez-Silva, Hugo and Sofia Sheidvasser (2000). 'The Educated Russian's Curse: Returns to Education in the Russian Federation', mimeo, Yale University.

[6] Berglof, Erik and Ludvig von Thadden (1999) "The Changing Corporate Governance Paradigm: Implications for Transition and Developing Countries". Conference Paper, Annual World Bank Conference on Development Economics, Washington D.C.

[7] Berliner, Joseph, The Innovation Decision in Soviet Industry. MIT Press, 1978.

[8] Black, Bernard, Reinier Kraakman, and Anna Tarassova, "Russian Privatization and Corporate Governance: What Went Wrong?" Stanford Law Review, Vol. 52, 2000.

[9] Biletsky, S., D. Brown, J. Earle, I. Komarov, and K. Sabirianova (1999), "Inside the Transforming Firm: Report on a Survey of Manufacturing Enterprises in Russia", DP SITE/Stockholm School of Economics, \#142. 
[10] Bilsen, Valentijn and Jozef Konings (1998). "Job Creation, Job Destruction, and Growth of Newly Established, Privatized, and State-Owned Enterprises in Transition Economics: Survey Evidence from Bulgaria, Hungary and Romania." Journal of Comparative Economics, vol 26 pp. 429-445.

[11] Brainerd, Elizabeth, "Market Reform and Mortality in Transition Economies," World Development, vol. 26, no. 11, 1998: 2013-2027.

[12] Blanchard, Olivier and Michael Kremer (1997) Disorganization. Quarterly Journal of Economics, 112 (4), pp. 1091-1226.

[13] Boeri, Tito and Christopher Flinn (1999). Returns to Mobility in the Transition to a Market Economy. Journal of Comparative Economics 27(1), pp.432 .

[14] Boeri, Tito, Michael Burda and Janos Kollo (1996). Mediating the Transition Labor Markets in Central and Eastern Europe. Economic Policy Intitiative, No.4, CEPR.

[15] Brada, Josef C., Arthur King, and Chia Ying Ma, "Industrial Economics of the Transition: Determinants of Enterprise Efficiency in Czechoslovakia and Hungary," Oxford Economic Papers, 49, 1997: 104-127.

[16] Brown, Annette, Barry W. Ickes, and Randi Ryterman, "The Myth of Monopoly: A New View of Industrial Structure in Russia," World Bank Policy Research Paper, 1994.

[17] Brown, David and John Earle (1999). Labor productivity in Russian financial industrial groups. Mimeo, Stockholm Institute of Transition Economies.

[18] Brown, David and John Earle (2000). 'Competition and Firm Performance: Lessons from Russia.' SITE Working Paper No. 154, Stockholm.

[19] Brown, David, Sergei Guriev and Tatiana Tchesnokova (1999). Vertical Integration and Market Foreclosure in Russian Economy. Mimeo, New Economic School, Moscow.

[20] Campos, Nauro and Fabrizio Coricelli (2000). Growth in Transition: What We Know, What We Don't, and What We Should. Mimeo, CERGE-EI. 
[21] Carlin, Wendy, Steven Fries, Mark Schaffer and Paul Seabright (2000). Competition and Enterprise Performance in Transition Economies. Mimeo, Cambridge University.

[22] Castanheira, Micael and Vladimir Popov (2000) Political Economy of Transition, mimeo, Graduate School of International Business, Academy of National Economy, Moscow.

[23] Collier, Paul and Jan Gunning (1999). 'The Microeconomics of African Growth, 1950-2000'. Mimeo, Worldbank.

[24] Simon Commander and Andrei Tolstopiatenko, Why Is Unemployment Low in the Former Soviet Union? Enterprise Restructuring and the Structure of Compensation, World Bank Policy Research Working Paper no. 1617, June 1996.

[25] Commander, Simon, and Mark Schankerman, "Enterprise Restructuring and Social Benefits," Economics of Transition, vol. 5, 1, May 1997: 1-24.

[26] Commander, Simon, Mark Dutz, and Nicholas Stern, "Restructuring in Transition Economies: Ownership, Competition, and Regulation," Annual Bank Conference on Economic Development Economics, The World Bank, April 1999.

[27] Cox, Donald, Zekeriya Eser, and Emmanuel Jimenez, "Family Safety Nets During Economic Transition: A Study of Inter-Household Transfers in Russia," Working Paper, Boston College, October 1995.

[28] Cox, Donald, Emmanuel Jimenez, and Wlodek Okrasa, "Family Safety Nets and Economic Transition: A Study of Worker Households in Poland," Working Paper, Boston College, May 1996.

[29] Criminal Code of the Russian Soviet Federative Socialist Republic, enacted Oct 27, 1960.

[30] Dearden, James, Barry W. Ickes, and Larry Samuelson, "To Innovate or Not to Innovate: Incentives for Innovation in Hierarchies," American Economic Review, 80, 5, December 1990.

[31] Denizer, C., and H. Wolf, "Household Savings in Transition Economies," NBER Working Paper 6457, March 1998. 
[32] Denizer, C., and H. Wolf, "Aggregate Savings in the Transition," mimeo, World Bank Research Project on Saving Across the World, December 1998.

[33] Djankov, Simeon and Peter Murrell, "Enterprise Restructuring in Transition: A Quantitative Survey," World Bank, April 2000.

[34] Earle, John and Klara Sabirianova (1999). Understanding Wage Arrears in Russia. Working Paper No.139, Stockholm Institute of Transition Economies.

[35] Easterly, W., and S. Fischer, "The Soviet Economic Decline," World Bank Economic Review, 1995, vol. 9, (3): 341-371.

[36] EBRD (1999) Transition Report 1999.

[37] Edlin, Aaron and Joseph Stiglitz (1995). 'Discouraging Rivals: Managerial Rent-Seeking and Economic Inefficiencies', American Economic Review, 80(5), 1301-12.

[38] Erhlich, Eva, "The Size Structure of Manufacturing Establishments and Enterprises: An International Comparison," Journal of Comparative Economics, vol. 9, 1985.

[39] Ericson, R.E., "The Structural Barrier to Transition Hidden in InputOutput Tables of Centrally Planned Economies," Economic Systems, forthcoming, 1999.

[40] Faggio, Giulia and Jozef Konings. Gross Job Flows and Firm Growth in Transition Countries: Evidence Using Firm Level Data on Five Countries. CEPR Discussion Paper No. 2261.

[41] Feldstein, Martin S., and Charles Horioka, "Domestic Savings and International Capital Flows," Economic Journal, 90, 1980: 314-329.

[42] Feschback, M., and A. Friendly, Ecocide in the USSR. Basic Books, 1992.

[43] Fischer, Stanley and Ratna Sahay (2000). 'The Transition Economies after Ten Years', IMF Working Paper 00/30.

[44] Filer, R.K., T. Gylfason, S. Jurajda, and J. Mitchell, "Market and Growth in the Post-Communist World," mimeo, CERGE-EI, 2000. 
[45] Filer, R.K., S. Jurajda, and J. Planovsky, "Returns to the Market: Valuing Human Capital in the Post-Soviet Transition Czech and Slovak Republics," mimeo, CERGE-EI, March 1999.

[46] Fogel, Robert W., "Economic Growth, Population Theory, and Physiology: The Bearing of Long-Term Processes on the Making of Economic Policy," American Economic Review, Vol. 84, No. 3, (Jun., 1994), pp. 369-395.

[47] Friebel, Guido and Sergei Guriev (2000a). Why Russian Workers Do Not Move: Attachment of Workers Through In-Kind Payments. CEPR Discussion Paper No. 2368.

[48] Friebel, Guido and Sergei Guriev (2000b). The Provision of Social Benefits in Russia: The Role of Local Authorities, mimeo, Stockholm Institute for Transition Economies.

[49] Frydman, R., Gray, C., Marek Hessel, and Andrzej Rapaczynski, "When Does Privatization Work: The Impact of Private Ownership on Corporate Performance in Transition Economies," Quarterly Journal of Economics, 114 (4), 1999: pp. 1153-1191.

[50] Frye, Timothy (1999). Keeping Shop: The Value of the Rule of Law in Warsaw and Moscow. Mimeo, Ohio State University.

[51] Frye, Timothy and Andrei Shleifer (1997). "The Invisible Hand and the Grabbing Hand," American Economic Review, pp. 354-359.

[52] Gaddy, Clifford, The Price of the Past: Russia's Struggle with the Legacy of a Militarized Economy, Washington, Brookings, 1996.

[53] Gaddy, Clifford and Barry W. Ickes. "To Restructure or Not To Restructure: Informal Activities and Enterprise Behavior in Transition", William Davidson Institute Working Paper,1998.

[54] Gaddy, Clifford and Barry W. Ickes, Russia's Virtual Economy, Washington, Brookings Institution, forthcoming.

[55] Garibaldi, Pietro, Nada Mora, Ratna Sahay, and Jeromi Zettelmeyer (1999). "What Moves Capital to Transition Economies?", Mimeo, IMF, Washington, D.C. 
[56] Gimpelson, Vladimir and Douglas Lippoldt (1999). "Labour Turnover in Russia: Evidence from the Administrative Reporting of Enterprises in Four Regions." IAS Working Paper, TE Series 1999/4, Vienna.

[57] Goskomstat of Russian Federation (1999). Russian Regions. Moscow.

[58] Granick, David, Job Rights in the Soviet Union: Their Consequences, Cambridge, Cambridge University Press, 1987.

[59] Grigoriev, L. and A.Kosarev (2000). On the Scale and Structure of the Capital Flight. Mimeo, Bureau of Economic Analysis, Moscow.

[60] Grossman, Gregory, "Price Control, Incentives, and Innovation in the Soviet Economy," in A. Abouchar, ed., The Socialist Price Mechansim, Durham, N.C., Duke University Press, 1977.

[61] Guariglia, Alessandra and Byung-Yeon Kim (1999). Unemployment Risk, Precautionary Savings, and Moonlighting in Russia. Mimeo, University of Essex.

[62] Guriev, Sergei and Barry W. Ickes (2000). "Barter in Russia", in Paul Seabright, Ed. The Vanishing Ruble: Barter and Currency Substitution in post-Soviet Societies. Cambridge University Press, forthcoming.

[63] Hart, Oliver (1995). Firms, Contracts and Financial Structure. Clarendon Lectures in Economics. Oxford University Press.

[64] Hayek, F., Collectivist economic planning : critical studies on the possibilities of socialism, by N. G. Pierson, Ludwig von Mises, George Halm, and Enrico Barone / edited, with an introduction and a concluding essay, by F. A. von Hayek, London : G. Routledge \& Sons, Ltd. 1935.

[65] Hendley, Kathryn, Barry W. Ickes, Peter Murrell, and Randi Ryterman, "Observations on the Use of Law in Russian Enterprises," Post-Soviet Affairs (formerly Soviet Economy), vol. 13, 1, Jan-March, 1997: 19-41.

[66] Hewett, Ed A., Reforming the Soviet Economy, Washington, Brookings, 1988.

[67] Ickes, B. W., "Saving in Eastern Europe and the Former Soviet Union," in Heertje, A., ed., World Savings: An International Survey, Basil Blackwell, 1993. 
[68] Ickes, B. W., Randi Ryterman, "Entry Without Exit: Economic Selection Under Socialism," Working Paper, The Pennsylvania State University, 1994.

[69] Ickes, B. W., Randi Ryterman, and Stoyan Tenev, "On Your Marx, Get Set, Go," Working Paper, The World Bank, 1995.

[70] Ickes, B. W., Peter Murrell, and Randi Ryterman, "End of the Tunnel? The Effects of Financial Stabilization in Russia," Post-Soviet Affairs (formerly Soviet Economy), vol. 13, 2, April-June, 1997:105-133.

[71] International Monetary Fund, The World Bank, Organization for Economic Cooperation and Development, and European Bank for Reconstruction and Development, A Study of the Soviet Economy, volume 2. Paris, 1991.

[72] Johnson, Simon, Daniel Kaufman and Oleg Ustenko, "Formal Employment and Survival Strategies After Communism," in Joan Nelson, Charles Tilley, and Lee Walker, eds., Transforming Post-Communist Political Economies, Washington, DC, National Academy Press, 1997.

[73] Johnson, Simon, Daniel Kaufman and Andrei Shleifer (1997). The Unofficial Economy in Transition. Brookings Papers on Economic Activity.

[74] Johnson, Simon, John McMillan and Christopher Woodruff (1999). Contract Enforcement in Transition. CEPR Discussion Paper No. 2081.

[75] Johnson, Simon, John McMillan and Christopher Woodruff (1999b). Property Rights, Finance and Entrepreneurship. Mimeo, UC San Diego.

[76] Johnson, Simon, Daniel Kaufmann, John McMillan and Christopher Woodruff (2000). Why Do Firms Hide: Bribes and Unofficial Activity After Communism. Journal of Public Economics, 76(3), pp. 495-520.

[77] Kapeliushnikov, Rostislav (1999). "On the Composition of the Russian Unemployment", Russian Economic Barometer, vol. 7, no. 2, p.18-41.

[78] Keane, Michael P., and Eswar S. Prasad, "Inequality, Transfers and Growth: New Evidence from the Economic Transition in Poland," IMF Working Paper, WP/00/117, June 2000.

[79] Konica, Nevila (1999). The Emigration Experience and Its Impact on the Albanian Economy. Ph.D. Thesis, CERGE-EI, Prague. 
[80] Konings, Jozef, and Alexandre Repkine (1998). 'The Effects of Competitive and Financial Pressure on the Technical Efficiency of Firms in Transition Economies: Frim Level Evidence from Bulgaria and Romania". mimeo, LICOS, Leuven.

[81] Konings, Jozef, and Patrick Paul Walsh (1999). 'Employment Dynamics of Newly Established and Traditional Firms: A Comparison of Russia and the Ukraine". LICOS Discussion Paper 81/1999, Leuven.

[82] Konings, Jozef, and Patrick Paul Walsh (1999). 'Disorganization in the Process of Transition: Firm-Level Evidence from Ukraine". Economics of Transition, $7(1)$.

[83] Kornai, Janos, The Socialist System: The Political Economy of Communism, Princeton, Princeton University Press, 1992.

[84] Korovilas, James (1999). The Albanian Economy in Transition: The Role of Remittances and Pyramid Investment Schemes. Post-Communist Economies, Vol. 11, No.3. pp.399-415.

[85] Krugman, Paul (1994). "The Myth of Asia's Miracle", Foreign Affairs, 73(6), pp. 62-78.

[86] Lambert-Mogiliansky, Ariane, Constantin Sonin and Ekaterina Zhuravskaya (2000). Capture of Bankruptcy: Theory and Evidence from Russia CEPR Discussion Paper 2488.

[87] Lavigne, Marie, The Economics of Transition: From Socialist Economy to Market Economy, St. Martins Press, New York, 1995.

[88] Liuhto, Carl (1999). The Impact of Environmental Stability on Strategic Planning - An Estonian Study. International Journal of Management, vol. 16, No.1.

[89] Marcinein, Anton, and Sweder van Wijnbergen, "The Impact of Czech Privatization Methods on Enterprise Performance Incorporating Initial Selection Bias," Economics of Transition, vol., 5, 2, May 1997: 289-304.

[90] Marin, Dalia and Monica Schnitzer. "Disorganization, Financial Squeeze and Barter". Mimeo, University of Munich, 1999. 
[91] Milanovic, Branko, Income, Inequality, and Poverty during the Transition from Planned to Market Economy. Washington, DC, The World Bank, 1998.

[92] Nesterova, Daria and Klara Sabirianova (1999). 'Investment in Human Capital under Economic Transformation in Russia.' EERC Working paper 99/04, Moscow.

[93] OECD Economic Surveys, Baltic States: A Regional Economic Assessment. Paris, February 2000.

[94] Ofer, Gur, "Soviet Economic Growth: 1928-1985," Journal of Economic Literature, December 1987.

[95] Ofer, Gur, and Aaron Vinokur, The Soviet Household Under the Old Regime, Cambridge, Cambridge University Press, 1992.

[96] Ofer, Gur, "Development and Transition," Mimeo, Hebrew University, 1999.

[97] Pohl, Gerhard, Robert Anderson, Stijn Claessens and Simeon Djankov (1997). "Privatization and Restructuring in Central and Eastern Europe: Evidence and Policy Options" World Bank Technical Paper No.368, World Bank, 1997.

[98] Pomfret, Richard, "Living Standards in Central Asia," Moct-Most, volume 9, 4, 1999: 395-421.

[99] Pop-Eleches, Cristian (1998). Transition in Romaina: Three Essays on Private Sector Development. Mimeo, Harvard University.

[100] Roland, Gerard and Thierry Verdier (1999). "Transition and the Output Fall". Economics of Transition, 7(1).

[101] Schaffer, Mark (1998). Do Firms in Transition Economies Have Soft Budget Constraints?, Journal of Comparative Economics , 26.

[102] Shapiro, Judith, "The Russian Mortality Crisis and its Causes," in A. Aslund, ed., Russian Economic Reform at Risk. London, Pinter Publishers, 1995.

[103] Shleifer Andrei and Robert Vishny, "Politicians and Firms," Quarterly Journal of Economics, CIX, 4, November 1994: 995-1025. 
[104] Shleifer, Andrei and Daniel Treisman (2000). Without a Map: Political Tactics and Economic Reform in Russia. MIT Press.

[105] Skoufias, Emmanuel, "Consumption Insurance in Transitional Economies: An Examination of the Role of Markets and Families in Bulgaria and Russia," Research Proposal to the National Council for Eurasian and East European Research, 1998.

[106] Smirnych, Larissa and Andreas Worgotter (2000). "Earnings, Gender and Mobility in Russia 1995-1998." IAS Working Paper, TE Series 2000/15, Vienna. [In German]

[107] Sorm, Vit and Katherine Terrell (1999) A Comparative Look at Labour Mobility in the Czech Republic: Where Have all the Workers Gone? CEPR Discussion Paper No. 2263.

[108] Svejnar, J., "Labor Markets in the Transitional Central and East European Economies," Handbook of Labor Economics, vol. 3-4, Amsterdam, North Holland, 1998.

[109] Walsh, Patrick Paul and Ciara Whelan (1999). 'Firm Performance and the Political Economy of Corporate Governance: Survey Evidence for Bulgaria, Hungary, Slovakia and Slovenia". LICOS Discussion Paper 85/1999, Leuven.

[110] Weitzman, Martin L., "Soviet Postwar Economic Growth and Capital-Labor Substitution," American Economic Review, vol. 60, 4, September 1970: ;676-692.

[111] Westin, Peter, "Export Revenues: Repatriation or Expropriation?," Russian Economic Trends, February 2000: 3-10.

[112] Wiles, P.J.D., The Political Economy of Communism, Oxford, Basil Blackwell, 1963.

[113] World Bank, World Development Report 1996: From Plan to Market, Oxford University Press, 1996.

[114] Young, Alwin (1995). "The Tyranny of Number: Confronting the Statistical Realities of the East Asian Growth", Quarterly Journal of Economics, CX(3), pp. 641-680. 
[115] Yudaeva, Ksenia, and Masha Gorban, "Health and Health Care," Russian Economic Trends, Vol. 8, 2, 1999: 27-35.

[116] Zettelmeyer, Jeromin (1998). "The Uzbek Growth Puzzle", IMF Working Paper 98/113. 


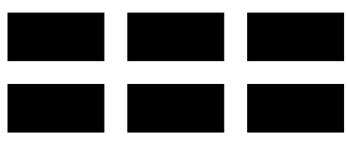

THE WILLIAM DAVIDSON INSTITUTE

AT THE UNIVERSITY OF MICHIGAN BUSINESSSCHOOL

\section{DAVIDSON INSTITUTE WORKING PAPER SERIES}

Working Papers are available at: www.wdi.bus.umich.edu

CURRENT AS OF $11 / 17 / 00$

\begin{tabular}{|c|c|c|}
\hline Publication & Authors & Date \\
\hline $\begin{array}{l}\text { No. } 348 \text { Microeconomic aspects of Economic Growth in Eastern } \\
\text { Europe and the Former Soviet Union, 1950-2000 }\end{array}$ & Sergei Guriev and Barry W. Ickes & Nov. 2000 \\
\hline $\begin{array}{l}\text { No. } 347 \text { Effective versus Statutory Taxation: Measuring Effective Tax } \\
\text { Administration in Transition Economies }\end{array}$ & $\begin{array}{l}\text { Mark E. Schaffer and Gerard } \\
\text { Turley }\end{array}$ & Nov. 2000 \\
\hline $\begin{array}{l}\text { No. } 346 \text { Objectives and Constraints of Entrepreneurs: Evidence from } \\
\text { Small and Medium Size Enterprises in Russia and Bulgaria }\end{array}$ & $\begin{array}{l}\text { Francesca Pissarides, Miroslav } \\
\text { Singer and Jan Svejnar }\end{array}$ & Oct. 2000 \\
\hline No. 345 Corruption and Anticorruption in the Czech Republic & $\begin{array}{l}\text { Lubomír Lízal and Evžen } \\
\text { Kočenda }\end{array}$ & Oct. 2000 \\
\hline No. 344 The Effects of Direct Foreign Investment on Domestic Firms & Jozef Konings & Oct. 2000 \\
\hline No. 343 On the Identification of Relative Wage Rigidity Dynamics & Patrick A. Puhani & Oct. 2000 \\
\hline $\begin{array}{l}\text { No. } 342 \text { The Determinants of Foreign Direct Investment in Transition } \\
\text { Economies }\end{array}$ & Alan A. Bevan and Saul Estrin & Oct. 2000 \\
\hline No. 341 The Global Spread of Stock Exchanges, 1980-1998 & Klaus Weber and Gerald F. Davis & Nov. 2000 \\
\hline $\begin{array}{l}\text { No. } 340 \text { The Costs and Benefits of Euro-isation in Central-Eastern } \\
\text { Europe Before or Instead of EMU Membership }\end{array}$ & D. Mario Nuti & Oct. 2000 \\
\hline No. 339 Debt Overhang and Barter in Russia & $\begin{array}{l}\text { Sergei Guriev, Igor Makarov and } \\
\text { Mathilde Maurel }\end{array}$ & Sept. 2000 \\
\hline $\begin{array}{l}\text { No. } 338 \text { Firm Performance and the Political Economy of Corporate } \\
\text { Governance: Survey Evidence for Bulgaria, Hungary, Slovakia and } \\
\text { Slovenia }\end{array}$ & $\begin{array}{l}\text { Patrick Paul Walsh and Ciara } \\
\text { Whela }\end{array}$ & July 2000 \\
\hline No. 337 Investment and Instability & $\begin{array}{l}\text { Nauro F. Campos and Jeffrey B. } \\
\text { Nugent }\end{array}$ & May 2000 \\
\hline $\begin{array}{l}\text { No. } 336 \text { The Evolution of the Insurance Sector in Central and } \\
\text { Eastern Europe and the former Soviet Union }\end{array}$ & Robert B.K. Pye & Aug. 2000 \\
\hline $\begin{array}{l}\text { No. } 335 \text { Institutional Technology and the Chains of Trust: Capital } \\
\text { Markets and Privatization in Russia and the Czech Republic }\end{array}$ & Bruce Kogut and Andrew Spicer & Aug. 2000 \\
\hline No. 334 The Evolution of Market Integration in Russia & $\begin{array}{l}\text { Daniel Berkowitz and David N. } \\
\text { DeJong }\end{array}$ & Aug. 2000 \\
\hline No. 333 Efficiency and Market Share in Hungarian Corporate Sector & László Halpern and Gábor Kőrösi & July 2000 \\
\hline No. 332 Search-Money-and-Barter Models of Financial Stabilization & $\begin{array}{l}\text { S.I. Boyarchenko and S.Z. } \\
\text { Levendorskii }\end{array}$ & July 2000 \\
\hline $\begin{array}{l}\text { No. } 331 \text { Worker Training in a Restructuring Economy: Evidence from } \\
\text { the Russian Transition }\end{array}$ & $\begin{array}{l}\text { Mark C. Berger, John S. Earle } \\
\text { and Klara Z. Sabirianova }\end{array}$ & Aug. 2000 \\
\hline $\begin{array}{l}\text { No. } 330 \text { Economic Development in Palanpur 1957-1993: A Sort of } \\
\text { Growth }\end{array}$ & Peter Lanjouw & Aug. 2000 \\
\hline $\begin{array}{l}\text { No. } 329 \text { Trust, Organizational Controls, Knowledge Acquisition from } \\
\text { the Foreign Parents, and Performance in Vietnamese International Joint } \\
\text { Ventures }\end{array}$ & $\begin{array}{l}\text { Marjorie A. Lyles, Le Dang } \\
\text { Doanh, and Jeffrey Q. Barden }\end{array}$ & June 2000 \\
\hline $\begin{array}{l}\text { No. } 328 \text { Comparative Advertising in the Global Marketplace: The } \\
\text { Effects of Cultural Orientation on Communication }\end{array}$ & $\begin{array}{l}\text { Zeynep Gürhan-Canli and } \\
\text { Durairaj Maheswaran }\end{array}$ & Aug. 2000 \\
\hline No. 327 Post Privatization Enterprise Restructuring & Morris Bornstein & July 2000 \\
\hline No. 326 Who is Afraid of Political Instability? & $\begin{array}{l}\text { Nauro F. Campos and Jeffrey B. } \\
\text { Nugent }\end{array}$ & July 2000 \\
\hline No. 325 Business Groups, the Financial Market and Modernization & Raja Kali & June 2000 \\
\hline $\begin{array}{l}\text { No. } 324 \text { Restructuring with What Success? A Case Study of Russian } \\
\text { Firms }\end{array}$ & Susan Linz & July 2000 \\
\hline
\end{tabular}


Davidson Institute Working Papers are available at: www.wdi.bus.umich.edu

\begin{tabular}{|c|c|c|}
\hline $\begin{array}{l}\text { No. } 323 \text { Priorities and Sequencing in Privatization: Theory and } \\
\text { Evidence from the Czech Republic }\end{array}$ & $\begin{array}{l}\text { Nandini Gupta, John C. Ham and } \\
\text { Jan Svejnar }\end{array}$ & May 2000 \\
\hline $\begin{array}{l}\text { No. } 322 \text { Liquidity, Volatility, and Equity Trading Costs Across } \\
\text { Countries and Over Time }\end{array}$ & $\begin{array}{l}\text { Ian Domowitz, Jack Glen and } \\
\text { Ananth Madhavan }\end{array}$ & Mar. 2000 \\
\hline $\begin{array}{l}\text { No. } 321 \text { Equilibrium Wage Arrears: A Theoretical and Empirical } \\
\text { Analysis of Institutional Lock-In }\end{array}$ & $\begin{array}{l}\text { John S. Earle and Klara Z. } \\
\text { Sabirianova }\end{array}$ & Oct. 2000 \\
\hline No. 320 Rethinking Marketing Programs for Emerging Markets & $\begin{array}{l}\text { Niraj Dawar and Amitava } \\
\text { Chattopadhyay }\end{array}$ & June 2000 \\
\hline $\begin{array}{l}\text { No. } 319 \text { Public Finance and Low Equilibria in Transition Economies; } \\
\text { the Role of Institutions }\end{array}$ & $\begin{array}{l}\text { Daniel Daianu and Radu } \\
\text { Vranceanu }\end{array}$ & June 2000 \\
\hline $\begin{array}{l}\text { No. } 318 \text { Some Econometric Evidence on the Effectiveness of Active } \\
\text { Labour Market Programmes in East Germany }\end{array}$ & $\begin{array}{l}\text { Martin Eichler and Michael } \\
\text { Lechner }\end{array}$ & June 2000 \\
\hline No. 317 A Model of Russia's "Virtual Economy" & R.E Ericson and B.W Ickes & May 2000 \\
\hline $\begin{array}{l}\text { No. } 316 \text { Financial Institutions, Financial Contagion, and Financial } \\
\text { Crises }\end{array}$ & $\begin{array}{l}\text { Haizhou Huang and Chenggang } \\
\text { Xu }\end{array}$ & Mar. 2000 \\
\hline $\begin{array}{l}\text { No. } 315 \text { Privatization versus Regulation in Developing Economies: The } \\
\text { Case of West African Banks }\end{array}$ & $\begin{array}{l}\text { Jean Paul Azam, Bruno Biais, and } \\
\text { Magueye Dia }\end{array}$ & eb. 2000 \\
\hline $\begin{array}{l}\text { No. } 314 \text { Is Life More Risky in the Open? Household Risk-Coping and } \\
\text { the Opening of China's Labor Markets }\end{array}$ & John Giles & pr. 2000 \\
\hline $\begin{array}{l}\text { No. } 313 \text { Networks, Migration and Investment: Insiders and Outsiders in } \\
\text { Tirupur's Production Cluster }\end{array}$ & $\begin{array}{l}\text { Abhijit Banerjee and Kaivan } \\
\text { Munshi }\end{array}$ & Mar. 2000 \\
\hline $\begin{array}{l}\text { No. } 312 \text { Computational Analysis of the Impact on India of the Uruguay } \\
\text { Round and the Forthcoming WTO Trade Negotiations }\end{array}$ & $\begin{array}{l}\text { Rajesh Chadha, Drusilla K. } \\
\text { Brown, Alan V. Deardorff and } \\
\text { Robert M. Stern }\end{array}$ & Mar. 2000 \\
\hline No. 311 Subsidized Jobs for Unemployed Wor & Jan. C. van Ours & May 2000 \\
\hline No. 310 Determinants of Managerial Pay in the Czech Republic & $\begin{array}{l}\text { Tor Eriksson, Jaromir Gottvald } \\
\text { and Pavel Mrazek }\end{array}$ & May 2000 \\
\hline $\begin{array}{l}\text { No. } 309 \text { The Great Human Capital Reallocation: An Empirical Analysis } \\
\text { of Occupational Mobility in Transitional Russia }\end{array}$ & Klara Z. Sabirianova & Oct. 2000 \\
\hline No. 308 Economic Development, Legality, and the Transplant Effect & 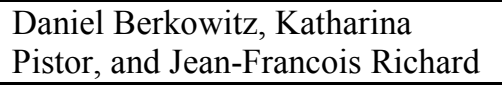 & Feb. 2000 \\
\hline $\begin{array}{l}\text { No. } 307 \text { Community Particip } \\
\text { Outcome: The Case of El Sal }\end{array}$ & Yasuyuki Sawada & Nov. 1999 \\
\hline No. 306 Gender Wage Gap and Segregation in Late Transition & Jurajda & May 2000 \\
\hline $\begin{array}{l}\text { No. } 305 \text { The Gender Pay Gap in the Transition from Communism: } \\
\text { Some Empirical Evidence }\end{array}$ & Andrew Newell and Barry Reilly & May 2000 \\
\hline No. 304 Post-Unification Wage Growth in East Germany & fer Hunt & Nov. 1998 \\
\hline $\begin{array}{l}\text { No. } 303 \text { How Does Privatization Affect Workers? The Case of the } \\
\text { Russian Mass Privatization Program }\end{array}$ & Elizabeth Brainerd & May 2000 \\
\hline $\begin{array}{l}\text { No. } 302 \text { Liability for Past Environmental Contamination and } \\
\text { Privatization }\end{array}$ & Dietrich Earnhart & Mar. 2000 \\
\hline No. 301 Varieties, Jobs and EU Enlargement & $\begin{array}{l}\text { Tito Boeri and Joaquim Oliveira } \\
\text { Martins }\end{array}$ & May 2000 \\
\hline No. $300 \mathrm{Emp}$ & Todd Idson & Apr. 2000 \\
\hline $\begin{array}{l}\text { No. } 299 \text { Information Complements, Substitutes, and Strategic Product } \\
\text { Design }\end{array}$ & $\begin{array}{l}\text { Geoffrey G. Parker and Marshall } \\
\text { W. Van Alstyne }\end{array}$ & Mar. 2000 \\
\hline $\begin{array}{l}\text { No. } 298 \text { Markets, Human Capital, and Inequality: Evidence from Rural } \\
\text { China }\end{array}$ & $\begin{array}{l}\text { Dwayne Benjamin, Loren Brandt, } \\
\text { Paul Glewwe, and Li Guo }\end{array}$ & May 2000 \\
\hline No. 297 Corporate Governance in the Asian Financial Crisis & $\begin{array}{l}\text { Simon Johnson, Peter Boone, } \\
\text { Alasdair Breach, and Eric } \\
\text { Friedman }\end{array}$ & Nov. 1999 \\
\hline No. 296 Competition and Firm Perforn & J. David Brown and John S. Earle & Mar. 2000 \\
\hline No. 295 Wage Determination in Russia: An Econometric Investigation & $\begin{array}{l}\text { Peter J. Luke and Mark E. } \\
\text { Schaffer }\end{array}$ & Mar. 2000 \\
\hline $\begin{array}{l}\text { No. 294: Can Banks Promote Enterprise Restruc } \\
\text { a Polish Bank's Experience }\end{array}$ & John P. Bonin and Bozena & 000 \\
\hline
\end{tabular}


Davidson Institute Working Papers are available at: www.wdi.bus.umich.edu

\begin{tabular}{|c|c|c|}
\hline No. 293: Why do Governments Sell Privatised Companies Abroad? & $\begin{array}{l}\text { Bernardo Bortolotti, Marcella } \\
\text { Fantini and Carlo Scarpa }\end{array}$ & Mar. 2000 \\
\hline $\begin{array}{l}\text { No. 292: Going Public in Poland: Case-by-Case Privatizations, Mass } \\
\text { Privatization and Private Sector Initial Public Offerings }\end{array}$ & Wolfgang Aussenegg & Dec. 1999 \\
\hline $\begin{array}{l}\text { No. 291: Institutional Technology and the Chains of Trust: Capital } \\
\text { Markets and Privatization in Russia and the Czech Republic }\end{array}$ & Bruce Kogut and Andrew Spicer & Mar. 1999 \\
\hline No. 290: Banking Crises and Bank Rescues: The Effect of Reputation & Jenny Corbett and Janet Mitchell & Jan. 2000 \\
\hline $\begin{array}{l}\text { No. 289: Do Active Labor Market Policies Help Unemployed Workers } \\
\text { to Find and Keep Regular Jobs? }\end{array}$ & Jan C. van Ours & Feb. 2000 \\
\hline No. 288: Consumption Patterns of the New Elite in Zimbabwe & Russell Belk & Feb. 2000 \\
\hline $\begin{array}{l}\text { No. 287: Barter in Transition Economies: Competing Explanations } \\
\text { Confront Ukranian Data }\end{array}$ & $\begin{array}{l}\text { Dalia Marin, Daniel Kaufmann } \\
\text { and Bogdan Gorochowskij }\end{array}$ & Jan. 2000 \\
\hline $\begin{array}{l}\text { No. 286: The Quest for Pension Reform: Poland's Security through } \\
\text { Diversity }\end{array}$ & $\begin{array}{l}\text { Marek Góra and Michael } \\
\text { Rutkowski }\end{array}$ & Jan. 2000 \\
\hline No. 285: Disorganization and Financial Collapse & $\begin{array}{l}\text { Dalia Marin and Monika } \\
\text { Schnitzer }\end{array}$ & Oct. 1999 \\
\hline No. 284: Coordinating Changes in M-form and U-form Organizations & $\begin{array}{l}\text { Yingyi Qian, Gérard Roland and } \\
\text { Chenggang Xu }\end{array}$ & May 1999 \\
\hline $\begin{array}{l}\text { No. 283: Why Russian Workers Do Not Move: Attachment of Workers } \\
\text { Through In-Kind Payments }\end{array}$ & Guido Friebel and Sergei Guriev & Oct. 1999 \\
\hline No. 282: Lessons From Fiascos in Russian Corporate Governance & $\begin{array}{l}\text { Merritt B. Fox and Michael A. } \\
\text { Heller }\end{array}$ & Oct. 1999 \\
\hline $\begin{array}{l}\text { No. 281: Income Distribution and Price Controls: Targeting a Social } \\
\text { Safety Net During Economic Transition }\end{array}$ & $\begin{array}{l}\text { Michael Alexeev and James } \\
\text { Leitzel }\end{array}$ & Mar. 1999 \\
\hline $\begin{array}{l}\text { No. 280: Starting Positions, Reform Speed, and Economic Outcomes in } \\
\text { Transitioning Economies }\end{array}$ & William Hallagan and Zhang Jun & Jan. 2000 \\
\hline No. 279 : The Value of Prominent Directors & $\begin{array}{l}\text { Miwa \& J. Mark } \\
\text { r }\end{array}$ & Oct. 1999 \\
\hline No. 278: The System Paradigm & Kornai & Apr. 1998 \\
\hline $\begin{array}{l}\text { No. 277: The Developmental Consequences of Foreign Direct } \\
\text { Investment in the Transition from Socialism to Capitalism: The } \\
\text { Performance of Foreign Owned Firms in Hungary }\end{array}$ & e Peter King & Sept. 1999 \\
\hline $\begin{array}{l}\text { No. 276: Stability and Disorder: An Evolutionary Analysis of Russia's } \\
\text { Virtual Economy }\end{array}$ & $\begin{array}{l}\text { Clifford Gaddy and Barry W. } \\
\text { Ickes }\end{array}$ & Nov. 1999 \\
\hline $\begin{array}{l}\text { No. 275: Limiting Government Predation Through Anonymous } \\
\text { Banking: A Theory with Evidence from China. }\end{array}$ & $\begin{array}{l}\text { Chong-En Bai, David D. Li, } \\
\text { Yingyi Qian and Yijiang Wang }\end{array}$ & July 1999 \\
\hline No. 274: Transition with Labour Supply & Tito Boeri & Dec. 1999 \\
\hline $\begin{array}{l}\text { No. 273: Sectoral Restructuring and Labor Mobility: A Comparative } \\
\text { Look at the Czech Republic }\end{array}$ & Vit Sorm and Katherine Terrell & Nov. 1999 \\
\hline $\begin{array}{l}\text { No. 272: Published in: Journal of Comparative Economics "Returns to } \\
\text { Human Capital Under the Communist Wage Grid and During the } \\
\text { Transition to a Market Economy" Vol. 27, pp. 33-60 } 1999 .\end{array}$ & $\begin{array}{l}\text { Daniel Munich, Jan Svejnar and } \\
\text { Katherine Terrell }\end{array}$ & Oct. 1999 \\
\hline $\begin{array}{l}\text { No. 271: Barter in Russia: Liquidity Shortage Versus Lack of } \\
\text { Restructuring }\end{array}$ & $\begin{array}{l}\text { Sophie Brana and Mathilde } \\
\text { Maurel }\end{array}$ & June 1999 \\
\hline $\begin{array}{l}\text { No. 270: Tests for Efficient Financial Intermediation with Application to } \\
\text { China }\end{array}$ & Albert Park and Kaja Sehrt & Mar. 1999 \\
\hline $\begin{array}{l}\text { No. 269a: Russian Privatization and Corporate Governance: What Went } \\
\text { Wrong? }\end{array}$ & $\begin{array}{l}\text { Bernard Black, Reinier Kraakman } \\
\text { and Anna Tarassova }\end{array}$ & May 2000 \\
\hline $\begin{array}{l}\text { No. 269: Russian Privatization and Corporate Governance: What Went } \\
\text { Wrong? }\end{array}$ & $\begin{array}{l}\text { Bernard Black, Reinier Kraakman } \\
\text { and Anna Tarassova }\end{array}$ & Sept. 1999 \\
\hline No. 268: Are Russians Really Ready for Capitalism? & Susan Linz & Sept. 1999 \\
\hline No. 267: Do Stock Markets Promote Economic Growth? & $\begin{array}{l}\text { Randall K. Filer, Jan Hanousek } \\
\text { and Nauro Campos }\end{array}$ & Sept. 1999 \\
\hline $\begin{array}{l}\text { No. 266: Objectivity, Proximity and Adaptability in Corporate } \\
\text { Governance }\end{array}$ & $\begin{array}{l}\text { Arnoud W.A Boot and Jonathan } \\
\text { R. Macey }\end{array}$ & Sept. 1999 \\
\hline
\end{tabular}




\begin{tabular}{|c|c|c|}
\hline $\begin{array}{l}\text { No. 265: When the Future is not What it Used to Be: Lessons from the } \\
\text { Western European Experience to Forecasting Education and Training in } \\
\text { Transitional Economies }\end{array}$ & $\begin{array}{l}\text { Nauro F. Campos, Gerard } \\
\text { Hughes, Stepan Jurajda, and } \\
\text { Daniel Munich }\end{array}$ & Sept. 1999 \\
\hline $\begin{array}{l}\text { No. 264: The Institutional Foundation of Foreign-Invested Enterprises } \\
\text { (FIEs) in China }\end{array}$ & Yasheng Huang & Sept. 1999 \\
\hline $\begin{array}{l}\text { No. 263: The Changing Corporate Governance Paradigm: Implications } \\
\text { for Transition and Developing Countries }\end{array}$ & $\begin{array}{l}\text { Erik Berglof and Ernst-Ludwig } \\
\text { von Thadden }\end{array}$ & June 1999 \\
\hline No. 262: Law Enforcement and Transition & $\begin{array}{l}\text { Gerard Roland and Thierry } \\
\text { Verdier }\end{array}$ & May 1999 \\
\hline $\begin{array}{l}\text { No. 261: Soft Budget Constraints, Pecuniary Externality, and the Dual } \\
\text { Track System }\end{array}$ & Jiahua Che & June 2000 \\
\hline $\begin{array}{l}\text { No. 260: Missing Market in Labor Quality: The Role of Quality Markets } \\
\text { in Transition }\end{array}$ & Gary & July 1999 \\
\hline $\begin{array}{l}\text { No. 259: Do Corporate Global Environmental Standards in Emerging } \\
\text { Markets Create or Destroy Market Value }\end{array}$ & $\begin{array}{l}\text { Glen Dowell, Stuart Hart and } \\
\text { Bernard Yeung }\end{array}$ & 1999 \\
\hline No. 258: Public Training and Outflows from Unemployment & Patrick A. P & June 1999 \\
\hline $\begin{array}{l}\text { No. 257: Ownership Versus Environment: Why are Public Sector Firms } \\
\text { Inefficient? }\end{array}$ & $\begin{array}{l}\text { Ann P. Bartel and Ann E. } \\
\text { Harrison }\end{array}$ & June 1999 \\
\hline $\begin{array}{l}\text { No. 256: Taxation and Evasion in the Presence of Exortion by } \\
\text { Organized Crime }\end{array}$ & $\begin{array}{l}\text { Michael Alexeev, Eckhard Ja } \\
\text { and Stefan Osborne }\end{array}$ & Jov. 1999 \\
\hline No. 255: Revisiting Hungary's Bankruptcy Episode & $\begin{array}{l}\text { John P. Bonin and Mark E. } \\
\text { Schaffer }\end{array}$ & 1999 \\
\hline No. 254: FDI in Em & Marina v.N Whitman & June 1999 \\
\hline $\begin{array}{l}\text { No. 253: The Asian Financial Crisis: What Happened } \\
\text { Done }\end{array}$ & $\begin{array}{l}\text { Jeffrey D. Sachs and Wing Thye } \\
\text { Woo }\end{array}$ & 1999 \\
\hline No. 252: Organizational Law as Asset Partitioning & $\begin{array}{l}\text { Henry Hansmann and Reinier } \\
\text { Kraakman }\end{array}$ & Sept. 1999 \\
\hline $\begin{array}{l}\text { No. 251: Cons } \\
\text { the Case of the }\end{array}$ & $\begin{array}{l}\text { nedict E. M. Steenkamp } \\
\text { ven M. Burgess }\end{array}$ & Sept. 1999 \\
\hline $\begin{array}{l}\text { No. 250: Property Rights Formation and the Organization of Exchange } \\
\text { and Production in Rural China }\end{array}$ & $\begin{array}{l}\text { W A. Turner, Loren } \\
\text {, and Scott Rozelle }\end{array}$ & July 1998 \\
\hline $\begin{array}{l}\text { No. 249: Impacts of the Indonesian Economic Crisis: Price Changes and } \\
\text { the Poor }\end{array}$ & $\begin{array}{l}\text { Jam } \\
\text { and }\end{array}$ & June 1999 \\
\hline $\begin{array}{l}\text { No. 248: Internal Barriers in the Transition of Enterprises from Central } \\
\text { Plan to Market }\end{array}$ & Charalambos Vlachoutsicos & July 1999 \\
\hline $\begin{array}{l}\text { No. 247: Spillovers from Multinationals in Developing Countries: the } \\
\text { Mechanisms at Work }\end{array}$ & d E. Caves & June 1999 \\
\hline $\begin{array}{l}\text { No. 246: Dynamism and Inertia on the Russian Labour Market: A } \\
\text { Model of Segmentation }\end{array}$ & $\begin{array}{l}\text { ena Grosfeld, Claudia Senik- } \\
\text { eygonie, Thierry Verdier, Stanislav } \\
\text { olenikov and Elena Paltseva }\end{array}$ & May 1999 \\
\hline No. 245: Les & John Bonin and Paul Wachtel & May 1999 \\
\hline $\begin{array}{l}\text { Tradeoffs and the Effects of Monetary Policy: } \\
\text { cee }\end{array}$ & Christian Popa & Dec. 1998 \\
\hline $\begin{array}{l}\text { No. 243: Privatization, Political Risk and Stock Market Development in } \\
\text { Emerging Economies }\end{array}$ & $\begin{array}{l}\text { Enrico C. Perotti and Pieter van } \\
\text { Oijen }\end{array}$ & Mar. 1999 \\
\hline No. 242: Investment Financing in Russian Financial-Industrial Groups & $\begin{array}{l}\text { Enrico C. Perotti and Stanislav } \\
\text { Gelfer }\end{array}$ & Oct. 1998 \\
\hline $\begin{array}{l}\text { rnments maintain hard budget constraints? Bank } \\
\text { ial isolation in Romania }\end{array}$ & $\begin{array}{l}\text { Octavian Carare, Constantijn } \\
\text { Claessens, Enrico C. Perotti } \\
\end{array}$ & Jan. 1999 \\
\hline $\begin{array}{l}\text { No. 240: Democratic Institutions and Economic Reform: the Polish } \\
\text { Case }\end{array}$ & $\begin{array}{l}\text { John E. Jackson, Jacek Klich, and } \\
\text { Krystyna Poznanska }\end{array}$ & Apr. 1998 \\
\hline No. 239: A Longitudinal Study of IJV Performance in Eastern Europe & $\begin{array}{l}\text { Keith D. Brouthers and Gary } \\
\text { Bamossy }\end{array}$ & June 1999 \\
\hline $\begin{array}{l}\text { No. 238: Published in: } \\
\text { and Economic Transitio }\end{array}$ & $\begin{array}{l}\text { John E. Jackson, Jacek Klich, } \\
\text { Krystyna Poznanska }\end{array}$ & July 1998 \\
\hline
\end{tabular}


No. 237: Analysis of Entrepreneurial Attitudes in Poland

|

No. 236: Investment and Finance in De Novo Private Firms: Empirical

Results from the Czech Republic, Hungary, and Poland

No. 235: Does a Soft Macroeconomic Environment Induce

Restructuring on the Microeconomic Level during the Transition

Period? Evidence from Investment Behavior of Czech Enterprises

No. 234: Banking Reform in China: Gradually Strengthening Pillar or Fragile Reed?

No. 233: Theories of Soft Budget Constraints and the Analysis of Banking Crises

No. 232: Unemployment Risk, Precautionary Savings, and

Moonlighting in Russia

No. 231: Investing in Turbulent Times: The Investment Behavior of

Polish Firms in the Transition

No. 230: The End of Moderate Inflation in Three Transition Economies?

No. 229: Back to the Future: The Growth Prospects of Transition

Economies Reconsidered

No. 228: The Enterprise Isolation Program in Russia

Concentration and Corporate Performance in the Czech Republic"

27(3), Sept. 1999, pp. 498-513.

No. 226: Unemployment Benefit Entitlement and Training Effects in Poland during Transition

No. 225: Transition at Whirlpool-Tatramat: Case Studies

No. 224: Measuring Progress in Transition and Towards EU Accession: A Comparison of Manufacturing Firms in Poland, Romania, and Spain

No. 223: Product Market Competition in Transition Economies:

Increasing Varieties and Consumer Loyalty

No. 222: Opaque Markets and Rapid Growth: the Superiority of Bank-

Centered Financial Systems for Developing Nations

No. 221: Technology Spillovers through Foreign Direct Investment

No. 220: Managerial, Expertise and Team Centered Forms of

Organizing: A Cross-Cultural Exploration of Independence in

Engineering Work

No. 219: Household Structure and Labor Demand in Agriculture:

Testing for Separability in Rural China

No. 218: Competing Strategies of FDI and Technology Transfer to

China: American and Japanese Firms

No. 217 Published in: Journal of Comparative Economics, "Returns to

Mobility in the Transition to a Market Economy" 27(1), Mar 1999.

No. 216 Published in: Journal of Comparative Economics, "Labor

Market Policies and Unemployment in the Czech Republic." 27(1), Mar

1999, pp. 33-60.

No. 215 Published in: Journal of Comparative Economics, "Active

Labor Market Policies in Poland: Human Capital Enhancement,

Stigmatization or Benefit Churning?" 27(1), Mar 1999, pp. 61- .

No. 214 Published in: Journal of Comparative Economics, "Does the

Slovenian Public Work Program Increase Participants' Chances to Find a Job?" 27(1), Mar 1999, pp. 113- .

No. 213 Published in: Journal of Comparative Economics, "Effects of

Active Labor Market Programs on the Transition Rate from

Unemployment into Regular Jobs in the Slovak Republic." 27(1), Mar

1999, pp. 90- .
John E. Jackson and Aleksander

S. Marcinkowski

Andrzej Bratkowski, Irena

Grosfeld, Jacek Rostowski

Lubomír Lízal

John Bonin

Janet Mitchell

Janet Mitchell

Alessandra Guariglia and Byung-

Yeon Kim

Josef C. Brada, Arthur E. King,

and Chia-Ying Ma

Josef C. Brada and Ali M. Kutan

Nauro F. Campos

Simeon Djankov

Stijn Claessens and Simeon

Djankov

Mar. 1997

Apr. 1999

June 1999

June 1999

Mar. 1999

June 1999

Apr. 1999

Apr. 1999

Apr. 1999

Apr. 1999

Apr. 1999

Patrick A. Puhani

Mar. 1999

\begin{tabular}{|l|l|}
\hline Hans Brechbuhl and Sonia & Mar. 1999
\end{tabular}

Ferencikova

Wendy Carlin, Saul Estrin, and

Mark Schaffer

\begin{tabular}{|l|l|}
\hline Mitsutoshi M. Adachi & Mar. 1999
\end{tabular}

Rodn

Rodney Wallace

July 1999

Yuko Kinoshita

Jan. 1999

Leslie Perlow

Jan. 1999

\begin{tabular}{|l|l|}
\hline Audra J. Bowlus and Terry & Jan. 1999
\end{tabular}

Sicular

\begin{tabular}{|l|l}
\hline W. Mark Fruin and Penelope & Jan. 1999
\end{tabular}

Prime

Tito Boeri and Christopher J.

Flinn

Katherine Terrell and Vit Sorm

Jan. 1999

Nov. 1998

Jochen Kluve, Hartmut Lehmann, $\quad$ Dec. 1998

and Christoph M. Schmidt

Milan Vodopivec

Dec. 1998

Martina Lubyova and Jan C. van

Dec. 1998

Ours 


\begin{tabular}{|c|c|c|}
\hline $\begin{array}{l}\text { No. 212: The Marketing System in Bulgarian Livestock Production - } \\
\text { The Present State and Evolutionary Processes During the Period of } \\
\text { Economic Transition }\end{array}$ & Yordan Staykov, Team Leader & Oct. 1998 \\
\hline No. 211: Bankruptcy Experience in Hungary and the Czech Republic & Janet Mitchell & Oct. 1998 \\
\hline $\begin{array}{l}\text { No 210: Values, Optimum Stimulation Levels and Brand Loyalty: New } \\
\text { Scales in New Populations }\end{array}$ & $\begin{array}{l}\text { Steven M. Burgess and Mari } \\
\text { Harris }\end{array}$ & Sept. 1998 \\
\hline No. 209: Inherited Wealth, Corporate Control and Economic Growth & $\begin{array}{l}\text { Randall K. Morck, David A. } \\
\text { Stangeland, and Bernard Yeung }\end{array}$ & Sept. 1998 \\
\hline $\begin{array}{l}\text { No. 208: A Cultural Analysis of Homosocial Reproduction and } \\
\text { Contesting Claims to Competence in Transitional Firms }\end{array}$ & Michael D. Kennedy & July 1998 \\
\hline $\begin{array}{l}\text { No. 207: From Survival to Success: The Journey of Corporate } \\
\text { Transformation at Haier. Forthcoming in Managing Organizational } \\
\text { Change in Transition Economies ed. Daniel Denison. }\end{array}$ & $\begin{array}{l}\text { Arthur Yeung and Kenneth } \\
\text { DeWoskin }\end{array}$ & July 1998 \\
\hline $\begin{array}{l}\text { No. 206: Why Do People Work If They Are Not Paid? An Example } \\
\text { from Eastern Europe. Forthcoming in Managing Organizational Change } \\
\text { in Transition Economies. }\end{array}$ & Irina L. Zinovieva & May 1998 \\
\hline $\begin{array}{l}\text { No. 205: Firm Ownership and Work Motivation in Bulgaria and } \\
\text { Hungary: An Empirical Study of the Transition in the Mid-1990s. } \\
\text { Forthcoming in Managing Organizational Change in Transition } \\
\text { Economies ed. Daniel Denison. }\end{array}$ & $\begin{array}{l}\text { Robert A. Roe, Irina L. } \\
\text { Zinovieva, Elizabeth Dienes, and } \\
\text { Laurens A. ten Horn }\end{array}$ & May 1998 \\
\hline $\begin{array}{l}\text { No. 204: Human Resource Management in the Restructuring of Chinese } \\
\text { Joint Ventures. Forthcoming in Managing Organizational Change in } \\
\text { Transition Economies ed. Daniel Denison. }\end{array}$ & Nandani Lynton & Apr. 1998 \\
\hline $\begin{array}{l}\text { No. 203: Emergent Compensation Strategies in Post-Socialist Poland: } \\
\text { Understanding the Cognitive Underpinnings of Management Practices } \\
\text { in a Transition Economy. Forthcoming in Managing Organizational } \\
\text { Change in Transition Economies ed. Daniel Denison. }\end{array}$ & Marc Weinstein & Mar. 1998 \\
\hline $\begin{array}{l}\text { No. 202: Corporate Transformation and Organizational Learning: The } \\
\text { People's Republic of China. Forthcoming in Managing Organizational } \\
\text { Change in Transition Economies ed. Daniel Denison. }\end{array}$ & $\begin{array}{l}\text { Meinolf Dierkes and Zhang } \\
\text { Xinhua }\end{array}$ & Mar. 1998 \\
\hline $\begin{array}{l}\text { No. 201: Foreign Direct Investment as a Factor of Change: The Case of } \\
\text { Slovakia. Forthcoming in Managing Organizational Change in } \\
\text { Transition Economies ed. Daniel Denison. }\end{array}$ & Sonia Ferencikova & Feb. 1998 \\
\hline $\begin{array}{l}\text { No. 200: Radical versus Incremental Change: The Role of Capabilities, } \\
\text { Competition, and Leaders. Forthcoming in Managing Organizational } \\
\text { Change in Transition Economies ed. Daniel Denison. }\end{array}$ & Karen L. Newman & Feb. 1998 \\
\hline $\begin{array}{l}\text { No. 199: The Emergence of Market Practices in China's Economic } \\
\text { Transition: Price Setting Practices in Shanghai's Industrial Firms. } \\
\text { Forthcoming in Managing Organizational Change in Transition } \\
\text { Economies ed. Daniel Denison. }\end{array}$ & Douglas Guthrie & Feb. 1998 \\
\hline $\begin{array}{l}\text { No. 198: The Application of Change Management Methods at Business } \\
\text { Organizations Operating in Hungary: Challenges in the Business and } \\
\text { Cultural Environment and First Practical Experiences. Forthcoming in } \\
\text { Managing Organizational Change in Transition Economies ed. Daniel } \\
\text { Denison. }\end{array}$ & Dr. János Fehér & Jan. 1998 \\
\hline $\begin{array}{l}\text { No. 197: Organizational Changes in Russian Industrial Enterprises: } \\
\text { Mutation of Decision-Making Structures and Transformations of } \\
\text { Ownership. Forthcoming in Managing Organizational Change in } \\
\text { Transition Economies ed. Daniel Denison. }\end{array}$ & Igor B. Gurkov & Jan. 1998 \\
\hline $\begin{array}{l}\text { No. 196: Understanding and Managing Challenges to the Romanian } \\
\text { Companies during Transition. Forthcoming in Managing Organizational } \\
\text { Change in Transition Economies ed. Daniel Denison. }\end{array}$ & $\begin{array}{l}\text { Dan Candea and Rodica M. } \\
\text { Candea }\end{array}$ & Jan. 1998 \\
\hline $\begin{array}{l}\text { No. 195: Insider Lending and Economic Transition: The Structure, } \\
\text { Function, and Performance Impact of Finance Companies in Chinese } \\
\text { Business Groups. Forthcoming in Managing Organizational Change in } \\
\text { Transition Economies ed. Daniel Denison. }\end{array}$ & Lisa A. Keister & Dec. 1997 \\
\hline
\end{tabular}




\begin{tabular}{|c|c|c|}
\hline $\begin{array}{l}\text { No. 194: Japanese Investment in Transitional Economies: } \\
\text { Characteristics and Performance. Forthcoming in Managing } \\
\text { Organizational Change in Transition Economies ed. Daniel Denison. }\end{array}$ & $\begin{array}{l}\text { Paul W. Beamish and Andrew } \\
\text { Delios }\end{array}$ & Nov. 1997 \\
\hline $\begin{array}{l}\text { No. 193: Building Successful Companies in Transition Economies. } \\
\text { Forthcoming in Managing Organizational Change in Transition } \\
\text { Economies ed. Daniel Denison. }\end{array}$ & Dr. Ivan Perlaki & Jan. 1998 \\
\hline $\begin{array}{l}\text { No. 192: Russian Communitariansim: An Invisible Fist in the } \\
\text { Transformation Process of Russia. Forthcoming in Managing } \\
\text { Organizational Change in Transition Economies ed. Daniel Denison. }\end{array}$ & Charalambos Vlachoutsicos & July 1998 \\
\hline No. 191: Teaching the Dinosaurs to Dance & Michal Cakrt & Sept. 1997 \\
\hline $\begin{array}{l}\text { No. 190: Strategic Restructuring: Making Capitalism in Post- } \\
\text { Communist Eastern Europe. Forthcoming in Managing Organizational } \\
\text { Change in Transition Economies ed. Daniel Denison. }\end{array}$ & Lawrence P. King & Sept. 1997 \\
\hline $\begin{array}{l}\text { No. 189: Published in: Regional Science and Urban Economics, } \\
\text { "Russia's Internal Border." 29(5), Sept. } 1999 .\end{array}$ & $\begin{array}{l}\text { Daniel Berkowitz and David N. } \\
\text { DeJong }\end{array}$ & July 1998 \\
\hline No. 187: Corporate Structure and Performance in Hungary & László Halpern and Gábor Kórsöi & July 1998 \\
\hline No. 186: Performance of Czech Companies by Ownership Structure & $\begin{array}{l}\text { Andrew Weiss and Georgiy } \\
\text { Nikitin }\end{array}$ & June 1998 \\
\hline $\begin{array}{l}\text { No. 185: Firm Performance in Bulgaria and Esto } \\
\text { competitive pressure, financial pressure and diso }\end{array}$ & Jozef Konings & July 1998 \\
\hline $\begin{array}{l}\text { No. 184: Investment and Wages during the Transition: Evidence from } \\
\text { Slovene Firms }\end{array}$ & Janez Prasnikar and Jan Svejnar & July 1998 \\
\hline $\begin{array}{l}\text { No. 183: Investment Portfolio under Soft Budget: Implications for } \\
\text { Growth, Volatility and Savings }\end{array}$ & Chongen Bai and Yijiang Wang & July 1998 \\
\hline No. 181: Delegation and Delay in Bank Privatization & $\begin{array}{l}\text { Loránd Ambrus-Lakatos and } \\
\text { Ulrich Hege }\end{array}$ & July 1998 \\
\hline No. 180: Financing Mechanisms and R\&D Investment & $\begin{array}{l}\text { Haizhou Huang and Chenggang } \\
\mathrm{Xu}\end{array}$ & July 1998 \\
\hline $\begin{array}{l}\text { No. 179: Organizational Culture and Effectiveness: The Case of Foreign } \\
\text { Firms in Russia }\end{array}$ & $\begin{array}{l}\text { Carl F. Fey and Daniel R. } \\
\text { Denison }\end{array}$ & Jan. 1999 \\
\hline No. 178: Output and Unemployment Dynamics in Transition & $\begin{array}{l}\text { Vivek H. Dehejia and Douglas W. } \\
\text { Dwyer }\end{array}$ & Jan. 1998 \\
\hline $\begin{array}{l}\text { No. 177: Published in: Economics of Transition, "Bureaucracies in the } \\
\text { Russian Voucher Privatization." } 8(1), 2000, \text { pp. 37-57. }\end{array}$ & Guido Friebel & June 1998 \\
\hline No. 176: Chronic Moderate Inflation in Transition: The Tale of Hungary & János Vincze & June 1998 \\
\hline No. 175: Privatisation and Market Structure in a Transition Economy & John Bennett and James Maw & June 1998 \\
\hline $\begin{array}{l}\text { No. 174: Ownership and Managerial Competition: Employee, Customer, } \\
\text { or Outside Ownership }\end{array}$ & $\begin{array}{l}\text { Patrick Bolton and Chenggang } \\
\mathrm{Xu}\end{array}$ & June 1998 \\
\hline $\begin{array}{l}\text { No. 173: Intragovernment Procurement of Local Public Good: A } \\
\text { Theory of Decentralization in Nondemocratic Government }\end{array}$ & $\begin{array}{l}\text { Chong-en Bai, Yu Pan and } \\
\text { Yijiang Wang }\end{array}$ & June 1998 \\
\hline No. 172: Political Instability and Growth in Proprietary Economies & $\begin{array}{l}\text { Jody Overland and Michael } \\
\text { Spagat }\end{array}$ & Aug. 1998 \\
\hline $\begin{array}{l}\text { No. 171: Published in Post-Communist Economies, "Framework Issues } \\
\text { in the Privatization Strategies of the Czech Republic, Hungary, and } \\
\text { Poland" 11(1) Mar. 1999. }\end{array}$ & Morris Bornstein & June 1998 \\
\hline $\begin{array}{l}\text { No. 170: Published in: European Journal of Political Economy } \\
\text { "Privatization, Ownership Structure and Transparency: How to Measure } \\
\text { a Real Involvement of the State" 15(4), Nov. 1999, pp. 605-18. }\end{array}$ & Frantisek Turnovec & May 1998 \\
\hline $\begin{array}{l}\text { No. } 169 \text { Published in: American Economic Review, "Unemployment and } \\
\text { the Social Safety Net during Transitions to a Market Economy: } \\
\text { Evidence from Czech and Slovak Men" 88(5), Dec 1998, pp. 1117-1142 }\end{array}$ & $\begin{array}{l}\text { John C. Ham, Jan Svejnar, and } \\
\text { Katherine Terrell }\end{array}$ & Dec. 1998 \\
\hline $\begin{array}{l}\text { No. 167: Voucher Privatization with Investment Funds: An Institutional } \\
\text { Analysis }\end{array}$ & David Ellerman & Mar. 1998 \\
\hline $\begin{array}{l}\text { No. 166: Published in: Marketing Issues in Transitional Economies, } \\
\text { "Value Priorities and Consumer Behavior in a Transitional Economy: } \\
\text { The Case of South Africa" ed. Rajeev Batra. }\end{array}$ & $\begin{array}{l}\text { Steven M. Burgess and Jan- } \\
\text { Benedict E.M. Steenkamp }\end{array}$ & Aug. 1998 \\
\hline
\end{tabular}




\begin{tabular}{|c|c|c|}
\hline $\begin{array}{l}\text { No. 164: Finance and Investment in Transition: Czech Enterprises, } \\
\text { 1993-1994 }\end{array}$ & $\begin{array}{l}\text { Ronald Anderson and Chantal } \\
\text { Kegels }\end{array}$ & Sept. 1997 \\
\hline $\begin{array}{l}\text { No. 163: European Union Trade and Investment Flows U-Shaping } \\
\text { Industrial Output in Central and Eastern Europe: Theory and Evidence }\end{array}$ & $\begin{array}{l}\text { Alexander Repkine and Patrick P. } \\
\text { Walsh }\end{array}$ & Apr. 1998 \\
\hline $\begin{array}{l}\text { No. 162: Skill Acquisition and Private Firm Creation in Transition } \\
\text { Economies }\end{array}$ & Zuzana Brixiova and Wenli Li & Oct. 1999 \\
\hline No. 161: Corruption in Transition & Susanto Basu and David D. Li & May 1998 \\
\hline $\begin{array}{l}\text { No. 160a: Tenures that Shook the World: Worker Turnover in Russia, } \\
\text { Poland and Britain }\end{array}$ & $\begin{array}{l}\text { Hartmut Lehmann and Jonathan } \\
\text { Wadsworth }\end{array}$ & Nov. 1999 \\
\hline $\begin{array}{l}\text { No. 160: Tenures that Shook the World: Worker Turnover in the } \\
\text { Russian Federation and Poland }\end{array}$ & $\begin{array}{l}\text { Hartmut Lehmann and Jonathan } \\
\text { Wadsworth }\end{array}$ & June 1998 \\
\hline No. 159: Does Market Structure Matter? New Evidence from Russia & $\begin{array}{l}\text { Annette N. Brown and J. David } \\
\text { Brown }\end{array}$ & June 1998 \\
\hline $\begin{array}{l}\text { No. 158: Structural Adjustment and Regional Long Term } \\
\text { Unemployment in Poland }\end{array}$ & $\begin{array}{l}\text { Hartmut Lehmann and Patrick P. } \\
\text { Walsh }\end{array}$ & June 1997 \\
\hline $\begin{array}{l}\text { No. 157: Baby Boom or Bust? Changing Fertility in Post-Communist } \\
\text { Czech Republic and Slovakia }\end{array}$ & Robert S. Chase & Apr. 1998 \\
\hline $\begin{array}{l}\text { No. } 156 \text { Published in: Leadership and Organization Development } \\
\text { Journal, "Leading Radical Change in Transition Economies." Vol. 19, } \\
\text { No. 6, 1998, pp. 309-324. }\end{array}$ & Karen L. Newman & June 1998 \\
\hline $\begin{array}{l}\text { No. } 155 \text { Published in: Oxford Review of Economic Policy, "From } \\
\text { Theory into Practice? Restructuring and Dynamism in Transition } \\
\text { Economies." Vol. 13, No. 2, Summer 1997, pp. 77-105. }\end{array}$ & $\begin{array}{l}\text { Wendy Carlin and Michael } \\
\text { Landesmann }\end{array}$ & June 1997 \\
\hline $\begin{array}{l}\text { No. 154: The Model and the Reality: Assessment of Vietnamese SOE } \\
\text { Reform-Implementation at the Firm Level }\end{array}$ & $\begin{array}{l}\text { Edmund Malesky, Vu Thanh } \\
\text { Hung, Vu Thi Dieu Anh, and } \\
\text { Nancy K. Napier }\end{array}$ & July 1998 \\
\hline $\begin{array}{l}\text { No. } 153 \text { Published in: Journal of Comparative Economics, "Causes of } \\
\text { the Soft Budget Constraint: Evidence on Three Explanations." Vol. 26, } \\
\text { No. 1, Mar. 1998, pp. 104-116. }\end{array}$ & David D. Li and Minsong Liang & Mar. 1998 \\
\hline $\begin{array}{l}\text { No. } 152 \text { Published in: Comparative Economic Studies, "Enterprise } \\
\text { Restructuring in Russia's Transition Economy: Formal and Informal } \\
\text { Mechanisms." Vol. 40, No. 2, Summer 1998, pp. 5-52. }\end{array}$ & Susan J. Linz and Gary Krueger & Apr. 1998 \\
\hline $\begin{array}{l}\text { No. 151: Labor Productivity in Transition: A Regional Analysis of } \\
\text { Russian Industry }\end{array}$ & Susan J. Linz & May 1998 \\
\hline $\begin{array}{l}\text { No. 150: Tax Avoidance and the Allocation of Credit. Forthcoming in } \\
\text { Financial Systems in Transition: The Design of Financial Systems in } \\
\text { Central Europe eds. Anna Meyendorff and Anjan Thakor. }\end{array}$ & Anna Meyendorff & June 1998 \\
\hline $\begin{array}{l}\text { No. 149: Commitment, Versatility and Balance: Determinants of Work } \\
\text { Time Standards and Norms in a Multi-Country Study of Software } \\
\text { Engineers }\end{array}$ & Leslie Perlow and Ron Fortgang & Apr. 1998 \\
\hline $\begin{array}{l}\text { No. 148: Changes in Poland's Transfer Payments in the 1990s: the Fate } \\
\text { of Pensioners }\end{array}$ & Bozena Leven & June 1998 \\
\hline $\begin{array}{l}\text { No. 147: Environmental Protection and Economic Development: The } \\
\text { Case of the Huaihe River Basin Cleanup Plan }\end{array}$ & $\begin{array}{l}\text { Robert Letovsky, Reze Ramazani, } \\
\text { and Debra Murphy }\end{array}$ & June 1998 \\
\hline $\begin{array}{l}\text { No. 146: Chief Executive Compensation During Early Transition: } \\
\text { Further Evidence from Bulgaria }\end{array}$ & $\begin{array}{l}\text { Derek C. Jones, Takao Kato, and } \\
\text { Jeffrey Miller }\end{array}$ & June 1998 \\
\hline $\begin{array}{l}\text { No. } 145 \text { Published in: Economics of Transition, "Women's } \\
\text { Unemployment During the Transition: Evidence from Czech and Slovak } \\
\text { Micro Data," Vol. 7, No. 1, May 1999, pp. 47-78. }\end{array}$ & $\begin{array}{l}\text { John Ham, Jan Svejnar, and } \\
\text { Katherine Terrell }\end{array}$ & May 1998 \\
\hline No. 144: Investment and Wages in Slovenia & Janez Prasnikar & May 1998 \\
\hline $\begin{array}{l}\text { No. } 143 \text { Published in: Review of Financial Studies, "Optimal } \\
\text { Bankruptcy Laws Across Different Economic Systems," 12(2), 47-77, } \\
\text { Summer 19993. }\end{array}$ & $\begin{array}{l}\text { Elazar Berkovitch and Ronen } \\
\text { Israel }\end{array}$ & Mar. 1998 \\
\hline $\begin{array}{l}\text { No. 142: Industrial Policy and Poverty in Transition Economies: Two } \\
\text { Steps Forward or One Step Back? }\end{array}$ & J. Linz & 1998 \\
\hline
\end{tabular}


Davidson Institute Working Papers are available at: www.wdi.bus.umich.edu

\begin{tabular}{|c|c|c|}
\hline $\begin{array}{l}\text { No. } 141 \text { Collective Ownership and Privatization of China's Village } \\
\text { Enterprises }\end{array}$ & Suwen Pan and Albert Park & Apr. 1998 \\
\hline $\begin{array}{l}\text { No. } 140 \text { A Comparative Look at Labor Mobility in the Czech Republic: } \\
\text { Where have all the Workers Gone? }\end{array}$ & Vit Sorm and Katherine Terrell & Apr. 1999 \\
\hline $\begin{array}{l}\text { No. } 139 \text { The Failure of the Government-Led Program of Corporate } \\
\text { Reorganization in Romania }\end{array}$ & $\begin{array}{l}\text { Simeon Djankov and Kosali } \\
\text { Ilayperuma }\end{array}$ & Sept. 1997 \\
\hline No. 138 Ownership and Employment in Russian Industry: 1992-1995 & Susan J. Linz & Mar. 1998 \\
\hline $\begin{array}{l}\text { No. } 137 \text { Published in: Journal of Political Economy, "Reform Without } \\
\text { Losers: An Interpretation of China's Dual-Track Approach to } \\
\text { Transition," Feb. 2000; Vol. 108, Iss.1; pg. } 120\end{array}$ & $\begin{array}{l}\text { Lawrence J. Lau, Yingyi Qian, } \\
\text { and Gerard Roland }\end{array}$ & Nov. 1997 \\
\hline $\begin{array}{l}\text { No. } 136 \text { Published in: European Economic Review, "The Political } \\
\text { Economy of Mass Privatization and the Risk of Expropriation," 44(2), } \\
\text { Feb. 2000, pgs. } 393-421\end{array}$ & Klaus M. Schmidt & Mar. 1998 \\
\hline $\begin{array}{l}\text { No. 135: Radical Organizational Change: The Role of Starting } \\
\text { Conditions, Competition, and Leaders }\end{array}$ & Karen L. Newman & Jan. 1998 \\
\hline $\begin{array}{l}\text { No. 134: To Restructure or Not to Restructure: Informal Activities and } \\
\text { Enterprise Behavior in Transition }\end{array}$ & $\begin{array}{l}\text { Clifford Gaddy and Barry W. } \\
\text { Ickes }\end{array}$ & May 1998 \\
\hline No. 133: Management 101: Behavior of Firms in Transition Economies & Josef C. Brada & Mar. 1998 \\
\hline $\begin{array}{l}\text { No. } 132 \text { Published in: Quarterly Journal of Economics, "Interfirm } \\
\text { Relationships and Informal Credit in Vietnam," 114(4), Nov. 1999, pgs. } \\
\text { 1285-1320 }\end{array}$ & $\begin{array}{l}\text { John McMillan and Christopher } \\
\text { Woodruff }\end{array}$ & Feb. 1998 \\
\hline $\begin{array}{l}\text { No. } 131 \text { Published in: Comparative Economic Studies, "Will } \\
\text { Restructuring Hungarian Companies Innovate? An Investigation Based } \\
\text { on Joseph Berliner's Analysis of Innovation in Soviet Industry." Vol. } \\
\text { 40, No. 2, Summer 1998, pp. 53-74. }\end{array}$ & John B. Bonin and Istvan Abel & Mar. 1998 \\
\hline $\begin{array}{l}\text { No. 130: Published in The American Economic Review, "Changing } \\
\text { Incentives of the Chinese Bureaucracy." May, 1998. }\end{array}$ & David D. Li & Jan. 1998 \\
\hline $\begin{array}{l}\text { No. 129: Restructuring Investment in Transition: A Model of the } \\
\text { Enterprise Decision }\end{array}$ & Richard E. Ericson & Jan. 1998 \\
\hline $\begin{array}{l}\text { No. } 128 \text { Published in: Comparative Economic Studies, "Job Rights in } \\
\text { Russian Firms: Endangered or Extinct Institutions?" Vol. 40, No. 4, } \\
\text { Winter 1998, pp. 1-32. }\end{array}$ & Susan J. Linz & Jan. 1998 \\
\hline No. 127: Accounting for Growth in Post-Soviet Russia & $\begin{array}{l}\text { Daniel Berkowitz and David N. } \\
\text { DeJong }\end{array}$ & Jan. 1998 \\
\hline $\begin{array}{l}\text { No. } 126 \text { Published in: Economics of Transition, "From Federalism, } \\
\text { Chinese Style, to Privatization Chinese Style," } 7(1), 1999 \text {, pgs. 103-31 }\end{array}$ & $\begin{array}{l}\text { Yuanzheng Cao, Yingyi Qian, } \\
\text { and Barry R. Weingast }\end{array}$ & Dec. 1997 \\
\hline $\begin{array}{l}\text { No. 125: Market Discipline in Conglomerate Banks: Is an Internal } \\
\text { Allocation of Cost of Capital Necessary as Incentive Device? } \\
\text { Forthcoming in Financial Systems in Transition: The Design of } \\
\text { Financial Systems in Central Europe eds. Anna Meyendorff and Anjan } \\
\text { Thakor. }\end{array}$ & $\begin{array}{l}\text { Arnoud W. A. Boot and Anjolein } \\
\text { Schmeits }\end{array}$ & Nov. 1997 \\
\hline $\begin{array}{l}\text { No. 124: Financial Discipline in the Enterprise Sector in Transition } \\
\text { Countries: How Does China Compare? }\end{array}$ & $\begin{array}{l}\text { Shumei Gao and Mark E. } \\
\text { Schaffer }\end{array}$ & Feb. 1998 \\
\hline $\begin{array}{l}\text { No. 123: Considerations of an Emerging Marketplace: Managers' } \\
\text { Perceptions in the Southern African Economic Community }\end{array}$ & Brent Chrite and David Hudson & Feb. 1998 \\
\hline No. 122: A Model of the Informal Economy in Transition Economies & $\begin{array}{l}\text { Simon Commander and Andrei } \\
\text { Tolstopiatenko }\end{array}$ & Nov. 1997 \\
\hline $\begin{array}{l}\text { No. 121: Local Labour Market Dynamics in the Czech and Slovak } \\
\text { Republics }\end{array}$ & $\begin{array}{l}\text { Peter Huber and Andreas } \\
\text { Worgotter }\end{array}$ & Nov. 1997 \\
\hline $\begin{array}{l}\text { No. 119: Institutional Upheaval and Company Transformation in } \\
\text { Emerging Market Economies }\end{array}$ & Karen L. Newman & Mar. 1998 \\
\hline No. 118: Industrial Decline and Labor Reallocation in Romania & John S. Earle & Oct. 1997 \\
\hline No. 117: Notes for an Essay on the Soft Budget Constraint & Lorand Ambrus-Lakatos & Jan. 1997 \\
\hline No. 116: Labor Demand During Transition in Hungary & Gabor Korosi & Oct. 1997 \\
\hline No. 115: Enterprise Performance and Managers' Profiles & $\begin{array}{l}\text { Simeon Djankov and Stijn } \\
\text { Claessens }\end{array}$ & Dec. 1997 \\
\hline
\end{tabular}




\begin{tabular}{|c|c|c|}
\hline $\begin{array}{l}\text { No. 114b Employment and Wages in Enterprises under Communism } \\
\text { and in Transition: Evidence From Central Europe and Russia }\end{array}$ & $\begin{array}{l}\text { Swati Basu, Saul Estrin, and Jan } \\
\text { Svejnar }\end{array}$ & Apr. 2000 \\
\hline $\begin{array}{l}\text { No. 114: Employment and Wage Behavior of Enterprises in Transitional } \\
\text { Economies }\end{array}$ & $\begin{array}{l}\text { Swati Basu, Saul Estrin, and Jan } \\
\text { Svejnar }\end{array}$ & Oct. 1997 \\
\hline $\begin{array}{l}\text { No. 113: Preliminary Evidence on Active Labor Programs' Impact in } \\
\text { Hungary and Poland }\end{array}$ & Christopher J. O'Leary & Oct. 1997 \\
\hline $\begin{array}{l}\text { No. 111: Unemployment Benefits and Incentives in Hungary: New } \\
\text { Evidence }\end{array}$ & Joachim Wolff & Oct. 1997 \\
\hline $\begin{array}{l}\text { No. 110: Published in: Empirical Economics, "Long-Term } \\
\text { Unemployment, Unemployment Benefits and Social Assistance: The } \\
\text { Polish Experience" Empirical-Economics; 23(1-2), 1998, pp. 55-85. }\end{array}$ & $\begin{array}{l}\text { Marek Gora and Christoph M. } \\
\text { Schmidt }\end{array}$ & Apr. 1997 \\
\hline $\begin{array}{l}\text { No. } 109 \text { Published in: Industrial and Labor Relations Review, "Markets } \\
\text { for Communist Human Capital: Returns to Education and Experience in } \\
\text { Post-Communist Czech Republic and Slovakia." 51(3), Apr. 1998, pp. } \\
\text { 401-423. }\end{array}$ & Robert S. Chase & Oct. 1997 \\
\hline $\begin{array}{l}\text { No. 107: The Worker-Firm Matching in the Transition: (Why) Are the } \\
\text { Czechs More Successful Than Others? }\end{array}$ & $\begin{array}{l}\text { Daniel Münich, Jan Svejnar, and } \\
\text { Katherine Terrell }\end{array}$ & Oct. 1997 \\
\hline $\begin{array}{l}\text { No. } 106 \text { Published in: Journal of Comparative Economics, "Job } \\
\text { Creation, Job Destruction and Growth of Newly Established, Privatized } \\
\text { and State-Owned Enterprises in Transition Economies: Survey Evidence } \\
\text { from Bulgaria, Hungary, and Romania," 26(3), Sept. 1998, pp. 429-445. }\end{array}$ & $\begin{array}{l}\text { Valentijn Bilsen and Jozef } \\
\text { Konings }\end{array}$ & Sept. 1998 \\
\hline $\begin{array}{l}\text { No. 105: Getting Behind the East-West [German] Wage Differential: } \\
\text { Theory and Evidence }\end{array}$ & $\begin{array}{l}\text { Michael Burda and Christoph } \\
\text { Schmidt }\end{array}$ & May 1997 \\
\hline No. 104: The Birth of the "Wage Curve" in Hungary, 1989-95 & Gabor Kertesi and Janos Kollo & Oct. 1997 \\
\hline $\begin{array}{l}\text { No. 103: Published in: Journal of Comparative Economics, "Grime and } \\
\text { Punishment: Job Insecurity and Wage Arrears in the Russian } \\
\text { Federation" 27, 595-617 (1999). }\end{array}$ & $\begin{array}{l}\text { Hartmut Lehmann, Jonathan } \\
\text { Wadsworth, and Alessandro } \\
\text { Acquisti }\end{array}$ & Oct. 1997 \\
\hline No. 102: Social Networks in Transition & $\begin{array}{l}\text { Lorena Barberia, Simon Johnson, } \\
\text { and Daniel Kaufmann } \\
\end{array}$ & Oct. 1997 \\
\hline $\begin{array}{l}\text { No. 101: Depreciation and Russian Corporate Finance: A Pro } \\
\text { Approach to Surviving the Transition }\end{array}$ & Susan J. Linz & Nov. 1997 \\
\hline No. 100: Romanian Financial System Reform & $\begin{array}{l}\text { Anna Meyendorff and Anj } \\
\text { Thakor }\end{array}$ & Nov. 1997 \\
\hline $\begin{array}{l}\text { No. 99: Proceedings of the Conference on Strategic Allianc } \\
\text { Transitional Economies, held May 20, } 1997 \text { at the Davidsor }\end{array}$ & Edited by Cynthia Koch & May 1997 \\
\hline No. 98: Institutions, Strain and the Unders & Daniel Daianu and I & Nov. 1997 \\
\hline No. 97: Struct & Daniel Daianu & Nov. 1997 \\
\hline $\begin{array}{l}\text { No. 96: Resource Misallocation and Strain: Explaining Shocks in Post- } \\
\text { Command Economies }\end{array}$ & Daniel Daianu & Nov. 1997 \\
\hline $\begin{array}{l}\text { No. 95: Published in: Finance-a-Uver, "Czech Money Market: Emerging } \\
\text { Links Among Interest Rates." 48(2) } 1998 \text { pp. 99-109. }\end{array}$ & $\begin{array}{l}\text { Jan Hanousek and Evzen } \\
\text { Kocenda }\end{array}$ & Nov. 1997 \\
\hline $\begin{array}{l}\text { No. 94: Pre-Reform Industry and the } \\
\text { State Monopsony in China }\end{array}$ & $\begin{array}{l}\text { Xiao-Yuan Dong and Louis } \\
\text { Putterman } \\
\end{array}$ & Oct. 1997 \\
\hline $\begin{array}{l}\text { No. 93: China's State-Owned Enterprises } \\
\text { In the First Reform Decade: } \\
\text { An Analysis of a Declining Monopsony }\end{array}$ & $\begin{array}{l}\text { Xiao-Yuan Dong and Louis } \\
\text { Putterman }\end{array}$ & Oct. 1997 \\
\hline No. 92: Expatriate Management in the Czech Republic & Richard B. Peterson & Sept. 1997 \\
\hline No. 91: China and the Idea of Economic Reform & Thomas G. Rawski & Apr. 1997 \\
\hline $\begin{array}{l}\text { No. } 90 \text { Published in: China Economic Review, "China's State Enterprise } \\
\text { Reform: An Overseas Perspective.” Vol. 8, Spring 1997, pp. 89-98. }\end{array}$ & Thomas G. Rawski & July 1997 \\
\hline $\begin{array}{l}\text { No. 89: The Economic Determinants of Internal Migration Flows in } \\
\text { Russia During Transition }\end{array}$ & Annette N. Brown & July 1997 \\
\hline $\begin{array}{l}\text { No. 88: Gender Wage Gaps in China's Labor Market: Size, Structure, } \\
\text { Trends }\end{array}$ & $\begin{array}{l}\text { Margaret Maurer-Fazio, Thomas } \\
\text { G. Rawski, and Wei Zhang }\end{array}$ & July 1997 \\
\hline No. 87: Privatisation in Central and Eastern Eur & Saul Estrin & June \\
\hline
\end{tabular}




\begin{tabular}{|c|c|c|}
\hline $\begin{array}{l}\text { No. 86: Published in : Economics of Transition, "The Effect of } \\
\text { Privatization on Wealth Distribution in Russia." v. 7, no. 2, 1999, pp. } \\
449-65\end{array}$ & Michael Alexeev & Feb. 1998 \\
\hline $\begin{array}{l}\text { No. 85: Was Privatization in Eastern Germany a Special Case? Some } \\
\text { Lessons from the Treuhand }\end{array}$ & Uwe Siegmund & Sept. 1997 \\
\hline No. 84: Start-ups and Transition & $\begin{array}{l}\text { Daniel M. Berkowitz and David J. } \\
\text { Cooper }\end{array}$ & Sept. 1997 \\
\hline $\begin{array}{l}\text { No. 83: Which Enterprises (Believe They) Have Soft Budgets after } \\
\text { Mass Privatization? Evidence from Mongolia }\end{array}$ & $\begin{array}{l}\text { James Anderson, Georges } \\
\text { Korsun, and Peter Murrell }\end{array}$ & Oct. 1997 \\
\hline $\begin{array}{l}\text { No. 82: Published in: European Economic Review, "Unemployment } \\
\text { Dynamics and the Restructuring of the Slovak Unemployment Benefit } \\
\text { System." Apr., } 1997 \text {. }\end{array}$ & $\begin{array}{l}\text { Martina Lubyova and Jan C. van } \\
\text { Ours }\end{array}$ & June 1997 \\
\hline No. 81: Determinants of Unemployment Duration in Russia & Mark C. Foley & Aug. 1997 \\
\hline No. 80: The Many Faces of Information Disclosure & $\begin{array}{l}\text { Arnoud W.A. Boot and Anjan V. } \\
\text { Thakor }\end{array}$ & Oct. 1997 \\
\hline $\begin{array}{l}\text { No. 79: Published in: Journal of Finance, "Foreign Speculators and } \\
\text { Emerging Equity Markets."v.22, iss. 2, 2000, pp. 565-613 }\end{array}$ & $\begin{array}{l}\text { Geert Bekaert and Campbell R. } \\
\text { Harvey }\end{array}$ & Aug. 1997 \\
\hline $\begin{array}{l}\text { No. 78: The Relationship Between Economic Factors and Equity } \\
\text { Markets in Central Europe }\end{array}$ & $\begin{array}{l}\text { Jan Hanousek and Randall K. } \\
\text { Filer }\end{array}$ & June 1997 \\
\hline $\begin{array}{l}\text { No. } 77 \text { Published in: Economics of Transition, "A Gini Decomposition } \\
\text { Analysis of Inequality in the Czech and Slovak Republics During the } \\
\text { Transition," Vol. 6, No.1, May 1998, pp. 23-46. }\end{array}$ & $\begin{array}{l}\text { Thesia I. Garner and Katherine } \\
\text { Terrell }\end{array}$ & May 1998 \\
\hline $\begin{array}{l}\text { No. 76: China's Emerging Market for Property Rights: Theoretical and } \\
\text { Empirical Perspectives }\end{array}$ & $\begin{array}{l}\text { Gary H. Jefferson and Thomas G. } \\
\text { Rawski }\end{array}$ & June 1997 \\
\hline $\begin{array}{l}\text { No. 75b: Test of Permanent Income Hypothesis on Czech Voucher } \\
\text { Privatization }\end{array}$ & Jan Hanousek and Zdenek Tima & Oct. 1997 \\
\hline $\begin{array}{l}\text { No. 74: Determinants of Performance of Manufacturing Firms in Seven } \\
\text { European Transition Economies }\end{array}$ & $\begin{array}{l}\text { Stijn Claessens, Simeon Djankov, } \\
\text { and Gerhard Pohl }\end{array}$ & Feb. 1997 \\
\hline $\begin{array}{l}\text { No. } 73 \text { Published in: Economics of Transition, "The Restructuring of } \\
\text { Large Firms in Slovak Republic." Vol. 6, No. 1, May 1998, pp. 67-85 }\end{array}$ & $\begin{array}{l}\text { Simeon Djankov and Gerhard } \\
\text { Pohl }\end{array}$ & May 1998 \\
\hline $\begin{array}{l}\text { No. 72: Law, Relationships, and Private Enforcement: Transactional } \\
\text { Strategies of Russian Enterprises }\end{array}$ & $\begin{array}{l}\text { Kathryn Hendley, Peter Murrell, } \\
\text { and Randi Ryterman }\end{array}$ & Nov. 1998 \\
\hline $\begin{array}{l}\text { No. 71: Giving Credit Where Credit Is Due: The Changing Role of } \\
\text { Rural Financial Institutions in China }\end{array}$ & $\begin{array}{l}\text { Albert Park, Loren Brandt, and } \\
\text { John Giles }\end{array}$ & Mar. 1997 \\
\hline $\begin{array}{l}\text { No. 70: Privatization Versus Competition: Changing Enterprise } \\
\text { Behavior in Russia }\end{array}$ & John S. Earle and Saul Estrin & $\begin{array}{l}\text { Spring } \\
1997\end{array}$ \\
\hline $\begin{array}{l}\text { No. 69: Russian Managers under Storm: Explicit Reality and Implicit } \\
\text { Leadership Theories (A Pilot Exploration) }\end{array}$ & Igor Gurkov & Oct. 1998 \\
\hline $\begin{array}{l}\text { No. 68: The Political Economy of Central-Local Relations in China: } \\
\text { Inflation and Investment Controls During the Reform Era }\end{array}$ & Yasheng Huang & $\begin{array}{l}\text { Spring } \\
1997\end{array}$ \\
\hline $\begin{array}{l}\text { No. 67: Between Two Coordination Failures: Automotive Industrial } \\
\text { Policy in China with a Comparison to Korea }\end{array}$ & Yasheng Huang & $\begin{array}{l}\text { Spring } \\
1997\end{array}$ \\
\hline $\begin{array}{l}\text { No. } 66 \text { Published in: Post-Soviet Geography and Economics, "Red } \\
\text { Executives in Russia's Transition Economy.” Vol. 27, No. 10, Nov. } \\
\text { 1996, pp. 633-651. }\end{array}$ & Susan J. Linz & Jan. 1997 \\
\hline $\begin{array}{l}\text { No. } 65 \text { Published in: Industrial and Corporate Change, "On the } \\
\text { Sequencing of Privatization in Transition Economies." Vol. 7, No. 1, } \\
1998 .\end{array}$ & $\begin{array}{l}\text { Gautam Ahuja and Sumit K. } \\
\text { Majumdar }\end{array}$ & Apr. 1997 \\
\hline $\begin{array}{l}\text { No. 64: Published in: Journal of Law and Economics, "Foreign } \\
\text { Ownership and Profitability: Property Rights, Control and the } \\
\text { Performance of Firms in Indian Industry" 42(1), Apr. 1999, pp. 209-38. }\end{array}$ & $\begin{array}{l}\text { Pradeep K. Chhibber and Sumit } \\
\text { K. Majumdar }\end{array}$ & Apr. 1997 \\
\hline No. 63: How Taxing Is Corruption on International Investors? & Shang-Jin Wei & Feb. 1997 \\
\hline $\begin{array}{l}\text { No. 62: What Can We Learn from the Experience of Transitional } \\
\text { Economies with Labour Market Policies? }\end{array}$ & Tito Boeri & 1997 \\
\hline
\end{tabular}




\begin{tabular}{|c|c|c|}
\hline $\begin{array}{l}\text { No. 61: Published in: Accounting Organizations and Society, } \\
\text { "Economic Transition, Strategy and the Evolution of Management } \\
\text { Accounting Practices: The Case of India" 24(5,6), Jul/Aug 1999, pp. } \\
\text { 379-412. }\end{array}$ & $\begin{array}{l}\text { Shannon W. Anderson and } \\
\text { William N. Lanen }\end{array}$ & Apr. 1997 \\
\hline $\begin{array}{l}\text { No. 60a: Enterprise Investment During the Transition: Evidence from } \\
\text { Czech Panel Data }\end{array}$ & Lubomír Lizal and Jan Svejnar & Dec. 1997 \\
\hline $\begin{array}{l}\text { No. 59: Published in: Journal of Law, Economics, and Organization, } \\
\text { "Institutional Environment, Community Government, and Corporate } \\
\text { Governance: Understanding China's Township-Village Enterprises." } \\
\text { 14(1), Apr. 1998, pages 1-23 }\end{array}$ & Jiahua Che and Yingyi Qian & Apr. 1997 \\
\hline No. 58: From the Grabbing Hand to the Helping Hand & Jiahua Che & June 2000 \\
\hline $\begin{array}{l}\text { No. 57: Published in: Brookings Papers on Economic Activity, "The } \\
\text { Unofficial Economy in Transition." 1: } 1998 .\end{array}$ & $\begin{array}{l}\text { Simon Johnson, Daniel } \\
\text { Kaufmann, and Andrei Schleifer }\end{array}$ & June 1997 \\
\hline No. 56: Taxes and Government Incentives: Eastern Europe vs. China & Roger H. Gordon and David D. Li & Apr. 1997 \\
\hline No. 55: Corruption and Reform & Susanto Basu and David Li & June 1996 \\
\hline $\begin{array}{l}\text { No. 54: Decentralization and the Macroeconomic Consequences of } \\
\text { Commitment to State-Owned Firms }\end{array}$ & Loren Brandt and Xiaodong Zhu & June 1997 \\
\hline $\begin{array}{l}\text { No. 53: Published in: The International Journal of Industrial } \\
\text { Organization, "Competitive Shocks and Industrial Structure: The Case } \\
\text { of Polish Manufacturing." Aug., 1999. . }\end{array}$ & $\begin{array}{l}\text { Pankaj Ghemawat and Robert E. } \\
\text { Kennedy }\end{array}$ & May 1997 \\
\hline $\begin{array}{l}\text { No. 52: Published in: The Quarterly Journal of Economics, "Insecure } \\
\text { Property Rights and Government Ownership of Firms." May, } 1998 .\end{array}$ & Jiahua Che and Yingyi Qian & May 1997 \\
\hline No. 51: Incentives, Scale Economies, and Organizational Form & $\begin{array}{l}\text { Eric Maskin, Yingyi Qian, and } \\
\text { Chenggang Xu }\end{array}$ & May 1997 \\
\hline $\begin{array}{l}\text { No. 50: Published in: Post-Soviet-Affairs, "End of the Tunnel? The } \\
\text { Effects of Financial Stabilization in Russia" Apr.-June 1997, pages 105- } \\
33\end{array}$ & $\begin{array}{l}\text { Barry W. Ickes, Peter Murrell, } \\
\text { and Randi Ryterman }\end{array}$ & Mar. 1997 \\
\hline $\begin{array}{l}\text { No. 49: The Evolution of Bank Credit Quality in Transition: Theory and } \\
\text { Evidence from Romania }\end{array}$ & $\begin{array}{l}\text { Enrico C. Perotti and Octavian } \\
\text { Carare }\end{array}$ & Oct. 1996 \\
\hline $\begin{array}{l}\text { No. 48: Where Do the Leaders Trade? Information Revelation and } \\
\text { Interactions Between the Segments of Czech Capital Markets }\end{array}$ & $\begin{array}{l}\text { Jan Hanousek and Libor } \\
\text { Nemecek }\end{array}$ & May 1997 \\
\hline $\begin{array}{l}\text { No. 47: Firms' Heterogeneity in Transition: Evidence from a Polish } \\
\text { Panel Data Set }\end{array}$ & $\begin{array}{l}\text { Irena Grosfeld and Jean-François } \\
\text { Nivet }\end{array}$ & May 1997 \\
\hline No. 46: Strategic Creditor Passivity, Regulation, and Bank Bailouts & Janet Mitchell & May 1997 \\
\hline $\begin{array}{l}\text { No. 45a: Published in: Journal of Public Economics, "Tax Rights in } \\
\text { Transition Economies: A Tragedy of the Commons." 76, 2000, pp. 369- } \\
397\end{array}$ & Daniel M. Berkowitz and Wei Li & Sept. 1997 \\
\hline $\begin{array}{l}\text { No. 44a: The Information Content of Stock Markets: Why do Emerging } \\
\text { Markets have Synchronous Stock Price Movements? (forthcoming in } \\
\text { the Journal of Financial Economics). }\end{array}$ & $\begin{array}{l}\text { Randall Morck, Bernard Yeung, } \\
\text { and Wayne Yu }\end{array}$ & Feb. 1999 \\
\hline $\begin{array}{l}\text { No. 43: Agency in Project Screening and Termination Decisions: Why } \\
\text { Is Good Money Thrown After Bad? }\end{array}$ & Chong-en Bai and Yijiang Wang & May 1997 \\
\hline $\begin{array}{l}\text { No. 42: Published in: Economics of Transition, "Channels of } \\
\text { Redistribution: Inequality and Poverty in the Russian Transition." Vol. } 7 \\
\text { (2) } 1999 .\end{array}$ & $\begin{array}{l}\text { Simon Commander, Andrei } \\
\text { Tolstopiatenko, and Ruslan } \\
\text { Yemtsov }\end{array}$ & May 1997 \\
\hline $\begin{array}{l}\text { No. 41: Published in: Economics of Transition, "Labour Market } \\
\text { Characteristics and Profitability: Econometric Analysis of Hungarian } \\
\text { Exporting Firms, 1986-1995" 6(1), May 1998, pages 145-62 }\end{array}$ & László Halpern and Gabor Korosi & May 1997 \\
\hline $\begin{array}{l}\text { No. 40: Published in: the Harvard Law Review, "The Tragedy of the } \\
\text { Anticommons: Property in the Transition from Marx to Markets." Jan. } \\
\text { 1998. }\end{array}$ & Michael Heller & Feb. 1997 \\
\hline No. 39: Privatization and Managerial Efficiency & $\begin{array}{l}\text { Olivier Debande and Guido } \\
\text { Friebel }\end{array}$ & May 1997 \\
\hline $\begin{array}{l}\text { No. } 38 \text { Published in: The Quarterly Journal of Econom } \\
\text { "Disorganization." Vol. 112, No. 4, Nov. 1997, pp. } 10\end{array}$ & $\begin{array}{l}\text { Olivier Blanchard and Michael } \\
\text { Kremer }\end{array}$ & 97 \\
\hline
\end{tabular}


Davidson Institute Working Papers are available at: www.wdi.bus.umich.edu

\begin{tabular}{|c|c|c|}
\hline $\begin{array}{l}\text { No. 37: Published in: Economics of Transition, "Transition and the } \\
\text { Output Fall." 7(1), 1999, pages 1-28. }\end{array}$ & $\begin{array}{l}\text { Gérard Roland and Thierry } \\
\text { Verdier }\end{array}$ & Mar. 1997 \\
\hline $\begin{array}{l}\text { No. 36: Restructuring an Industry During Transition: A Two-Period } \\
\text { Model }\end{array}$ & Richard Ericson & Sept. 1996 \\
\hline No. 34: The East-West Joint Venture: BC Torsion Case Study & $\begin{array}{l}\text { Sonia Ferencikova and Vern } \\
\text { Terpstra }\end{array}$ & Dec. 1998 \\
\hline $\begin{array}{l}\text { No. } 33 \text { Published in: Journal of Comparative Economics, "Quantifying } \\
\text { Price Liberalization in Russia." Vol. 26, No. 4, Dec. 1998, pp. 735-737. }\end{array}$ & $\begin{array}{l}\text { Daniel Berkowitz, David DeJong, } \\
\text { and Steven Husted }\end{array}$ & Dec. 1998 \\
\hline No. 32: What Can North Korea Learn from China's Market Reforms? & John McMillan & Sept. 1996 \\
\hline $\begin{array}{l}\text { No. 31: Published in: China-Economic-Review, "Towards a Model of } \\
\text { China as a Partially Reformed Developing Economy Under a } \\
\text { Semifederalist Government." 9(1), Spring 1998, pages 1-23. }\end{array}$ & Yijiang Wang and Chun Chang & Mar. 1997 \\
\hline $\begin{array}{l}\text { No. 30: Convergence in Output in Transition Economies: Central and } \\
\text { Eastern Europe, 1970-1995 }\end{array}$ & Saul Estrin and Giovanni Urga & Feb. 1997 \\
\hline $\begin{array}{l}\text { No. 29: Published in: Economics of Transition, "Altered Band and } \\
\text { Exchange Volatility." Volume 6, no. 1, 1998, 173-181. }\end{array}$ & Evzen Kocenda & Mar. 1997 \\
\hline $\begin{array}{l}\text { No. 28: Published in: Quarterly Journal of Economics, "Public Versus } \\
\text { Private Ownership of Firms: Evidence from Rural China." Volume 113, } \\
\text { no. 3, Aug. 1998, 773-808. }\end{array}$ & Hehui Jin and Yingyi Qian & Jan. 1997 \\
\hline $\begin{array}{l}\text { No. 27: East-West Joint Ventures in a Transitional Economy: The Case } \\
\text { of Slovakia }\end{array}$ & Sonia Ferencikova & Mar. 1997 \\
\hline $\begin{array}{l}\text { No. 26: Published in Economic Analysis "Behavior of a Slovenian Firm } \\
\text { in Transition" Vol. 1, no. 1, 1998, 57-73. }\end{array}$ & Janez Prasnikar & Feb. 1997 \\
\hline $\begin{array}{l}\text { No. 25: Cultural Encounters and Claims to Expertise in Postcommunist } \\
\text { Capitalism }\end{array}$ & Michael D. Kennedy & Feb. 1997 \\
\hline $\begin{array}{l}\text { No. 24: ZVU a.s.: Investment Funds on the Board of Directors of an } \\
\text { Engineering Giant }\end{array}$ & Tory Wolff & Aug. 1995 \\
\hline $\begin{array}{l}\text { No. 23: The Role of Investment Funds in the Czech Republic (joint } \\
\text { publication with Czech Management Center) }\end{array}$ & Dusan Triska & June 1996 \\
\hline $\begin{array}{l}\text { No. 22: Czech Investment Fund Industry: Development and Behaviour } \\
\text { (joint publication with Czech Management Center) }\end{array}$ & Richard Podpiera & May 1996 \\
\hline $\begin{array}{l}\text { No. 21: Restructuring of Czech Firms: An Example of Gama, a.s. (joint } \\
\text { publication with Czech Management Center) }\end{array}$ & Antonin Bulin & June 1996 \\
\hline $\begin{array}{l}\text { No. 20: YSE Funds: A Story of Czech Investment Funds (joint } \\
\text { publication with Czech Management Center) }\end{array}$ & Michal Otradovec & Nov. 1995 \\
\hline $\begin{array}{l}\text { No. 19: První Investicni a.s., The First Investment Corporation (joint } \\
\text { publication with Czech Management Center) }\end{array}$ & Jaroslav Jirasek & Aug. 1995 \\
\hline $\begin{array}{l}\text { No. 18: PPF a.s., The First Private Investment Fund (joint publication } \\
\text { with Czech Management Center) }\end{array}$ & Michal Otradovec & Nov. 1995 \\
\hline $\begin{array}{l}\text { No. } 17 \text { Published in: Post-Soviet Geography and Economics, "Russia's } \\
\text { Managers in Transition: Pilferers or Paladins?" 37(7) (Sept. 1996), pp. } \\
\text { 397-426. }\end{array}$ & Susan J. Linz and Gary Krueger & Nov. 1996 \\
\hline $\begin{array}{l}\text { No. 16: Banks in Transition-Investment Opportunities in Central } \\
\text { Europe and Russia, Edited Transcript from } 31 \text { May } 1996 \text { Conference in } \\
\text { New York City }\end{array}$ & $\begin{array}{l}\text { With commentary and edited by } \\
\text { Anna Meyendorff }\end{array}$ & Jan. 1997 \\
\hline $\begin{array}{l}\text { No. 15: Marketing in Transitional Economies: Edited Transcript \& } \\
\text { Papers from } 1 \text { Apr. } 1996 \text { Conference in Ann Arbor, Michigan }\end{array}$ & $\begin{array}{l}\text { Compiled by The Davidson } \\
\text { Institute }\end{array}$ & Dec. 1996 \\
\hline $\begin{array}{l}\text { No. 14: Pensions in the Former Soviet Bloc: Problems and Solutions. } \\
\text { Published by Council on Foreign Relations. "The Coming Global } \\
\text { Pension Crisis" New York, } 1997\end{array}$ & Jan Svejnar & Nov. 1996 \\
\hline $\begin{array}{l}\text { No. 13: Enterprise Restructuring and Performance in the Transition. } \\
\text { Forthcoming in Financial Systems in Transition: The Design of } \\
\text { Financial Systems in Central Europe eds. Anna Meyendorff and Anjan } \\
\text { Thakor. }\end{array}$ & $\begin{array}{l}\text { Lubomir Lizal, Miroslav Singer, } \\
\text { and Jan Svejnar }\end{array}$ & Dec. 1996 \\
\hline
\end{tabular}


Davidson Institute Working Papers are available at: www.wdi.bus.umich.edu

\begin{tabular}{|c|c|c|c|}
\hline \multicolumn{2}{|c|}{$\begin{array}{l}\text { No. } 12 \text { Published in: Journal of International Marketing, "Executive } \\
\text { Insights: Marketing Issues and Challenges in Transitional Economies." } \\
\text { Vol. 5, No. 4, 1997, pp. 95-114. Also published in: Marketing Issues in } \\
\text { Transitional Economies ed. Rajeev Batra. }\end{array}$} & Rajeev Batra & Apr. 1997 \\
\hline \multicolumn{2}{|c|}{$\begin{array}{l}\text { No. 11: Worker Trust and System Vulnerability in the Transition from } \\
\text { Socialism to Capitalism }\end{array}$} & Andrew Schotter & Aug. 1996 \\
\hline \multicolumn{2}{|c|}{$\begin{array}{l}\text { No. } 10 \text { Published in: Comparative Economic Studies, "Russian Firms in } \\
\text { Transition: Champions, Challengers, and Chaff." Vol. 39, No.2, } \\
\text { Summer 1997, pp. 1-36. }\end{array}$} & Susan J. Linz & July 1996 \\
\hline \multicolumn{2}{|l|}{$\begin{array}{l}\text { No. 9: Corporate Debt Crisis and Bankruptcy Law During the } \\
\text { Transition: The Case of China }\end{array}$} & David D. Li and Shan Li & Dec. 1995 \\
\hline \multicolumn{2}{|c|}{$\begin{array}{l}\text { No. } 8 \text { Published in: Journal of Comparative Economics, "A Theory of } \\
\text { Ambiguous Property Rights in Transition Economies: The Case of the } \\
\text { Chinese Non-State Sector." Vol. 23, No. 1, Aug. 1996, pp. 1-19. }\end{array}$} & . $\mathrm{Li}$ & June 1996 \\
\hline \multicolumn{2}{|l|}{$\begin{array}{l}\text { No. 7: The Foreign Economic Contract Law of China: Cases and } \\
\text { Analysis }\end{array}$} & $\overline{\text { Dor }}$ & June 1993 \\
\hline \multicolumn{2}{|c|}{$\begin{array}{l}\text { No. 3: Bank Privatization in Hungary and the Magyar Kulkereskedelmi } \\
\text { Bank Transaction }\end{array}$} & $\begin{array}{l}\text { Roger Kormendi and Karen } \\
\text { Schnatterly }\end{array}$ & May 1996 \\
\hline $\begin{array}{l}\text { Replacing No. 1: Journal of Comparative Economics } \\
\text { Symposium on "Bank Privatization in Central Europe and } \\
\text { Russia." Vol. 25, No. 1, Aug. } 1997 .\end{array}$ & \multicolumn{2}{|c|}{$\begin{array}{l}\text { "Bank Privatization in Transitional } \\
\text { Economies," Roger Kormendi and Edward } \\
\text { Snyder. }\end{array}$} & Aug. 1997 \\
\hline $\begin{array}{l}\text { Replacing No. 2: Journal of Comparative Economics } \\
\text { Symposium on "Bank Privatization in Central Europe and } \\
\text { Russia." Vol. 25, No. 1, Aug. } 1997 .\end{array}$ & \multicolumn{2}{|c|}{$\begin{array}{l}\text { "Transactional Structures of Bank } \\
\text { Privatizations in Central Europe and } \\
\text { Russia," Anna Meyendorff and Edward A. } \\
\text { Snyder. }\end{array}$} & Aug. 1997 \\
\hline $\begin{array}{l}\text { Replacing No. 4: Journal of Comparative Economics } \\
\text { Symposium on "Bank Privatization in Central Europe and } \\
\text { Russia." Vol. 25, No. 1, Aug. } 1997 .\end{array}$ & \multicolumn{2}{|c|}{$\begin{array}{l}\text { "Bank Privatization in Poland: The Case of } \\
\text { Bank Slaski," Jeffery Abarbaness and John } \\
\text { Bonin. }\end{array}$} & Aug. 1997 \\
\hline $\begin{array}{l}\text { Replacing No. 5: Journal of Comparative Economics } \\
\text { Symposium on "Bank Privatization in Central Europe and } \\
\text { Russia." Vol. 25, No. 1, Aug. } 1997 .\end{array}$ & \multicolumn{2}{|c|}{$\begin{array}{l}\text { "Bank Privatization in Post-Communist } \\
\text { Russia: The Case of Zhilsotsbank," Jeffery } \\
\text { Abarbanell and Anna Meyendorff } \\
\end{array}$} & Aug. 1997 \\
\hline $\begin{array}{l}\text { Replacing No. 6: Journal of Comparative Economics } \\
\text { Symposium on "Bank Privatization in Central Europe and } \\
\text { Russia." Vol. 25, No. 1, Aug. } 1997 .\end{array}$ & \multicolumn{2}{|c|}{$\begin{array}{l}\text { "The Czech Republic's Commercial Bank: } \\
\text { Komercni Banka," Edward A. Snyder and } \\
\text { Roger C. Kormendi. }\end{array}$} & Aug \\
\hline
\end{tabular}

